\title{
小臼歯における雬䯣腔および硬組織の増鈴的変化
}

\author{
九州歯科大学大学院菌学研究科口腔解剖学第 1 専攻（指導：山田博教授）
}

西田宗岡

昭和 56 年 1 月 22 日受付

\begin{abstract}
本論文の要旨は，第 20 回歯科基礎医学会総会（昭和53年 9 月 24 日岐阜），第 35 回日本解剖学会九 州地方会（昭和54年11月11日宮崎）および第40回九州雨科学会総会（昭和55年 6 月 14 日北九州）に おいて発表した。
\end{abstract}

\section{Age Changes of the Pulp Cavity and the Hard Tissues of the Human Premolars}

Munetake Nishida

First Department of Oral Anatomy (Director : Prof. Hiroshi Yamada)

Kyushu Dental College, Kitakyushu, Japan

It is well known that the diametrical size of the enamel, dentin, cement layers and the pulp cavity of the human teeth change with aging. But, only a limited number of quantitative study on this issue have so far been made. In this study, a total of 325 human premolars were cross-sectionally cut into ten sections with the purpose of examining the age changes of the pulp cavity and the hard tissues. All premolars were classified into four age groups, $10-19,20-39,40-49$ and over 50 . Especially, the upper premolars were further classified into following three types according to the morphology of the root. A : a single root with a single canal. B : a single root with double canals. $\mathrm{C}$ : double roots with double canals. The age change of diametrical size of each hard tissue and pulp cavity was examined both mesio-distally and buccolingually, and relative change was examined. As a result, following observations were obtained.

1. The diametrical size of enamel layers decreased both mesio-distally and buccolingually with aging, especially in age groups over 40 , the decrease was evident. This tendency was most apparent in upper first premolars. In direction, mesio-distal decrease was more apparent in general, but the reverse tendency was observed in lower premolars aged over 40 years.

2. The diametrical size of dentin layers increased with aging. This phenomenon was observed in almost everywhere except for crown portion, and it was most evident in upper first premolars. Among upper first premolars, type A showed this tendency most apparently. These changes were most active in age groups $10-39$. In direction, 
there was no significant relative change between the mesio-distal and bucco-lingual size of dentin layers.

3. The diametrical size of cement layers increased with aging. This phenomenon was more apparent in the first premolars than the second premolars both in the upper and the lower side. The increasing ratio at the middle and at the apical portion of a root seemed to be the same. The increasing ratio in premolars with a single canal seemed to be higher than that in premolars with double canals. This tendency was most apparent in the age groups $10-39$. In direction, there was no significant relative change between the mesio-distal and bucco-lingual sizes of cement layers.

4. The diametrical size of pulp cavity decreased with aging. This tendency was most apparent in premolars with a single root canal, and in age groups $10-39$. In direction, there was no significant relative change of the diametrical size of pulp cavities in upper premolars. In lower premolars, however, the mesio-distal decreasing ratio was higher at cervical portion. On the contrary, the bucco-lingual decreasing ratio was higher at the middle and the apical portion of the root.

\section{緒言}

日檫队に萌出して完成された米は，基本的には永人に その形態を変化させることはない，しかしながら，その 後生涯を通して生理的あるいは病理的要因によって常に 何らかの構造または形態の変化を継続するものである。 すなわち，年粭の増加と歯固有の生理的機能によって雬 自体は，形態の変化をきたさざるを得ない，それらの主 なものとして, 咬耗, 磨耗, 雪根部の肥厚などの外観か ら認められる外形変化と菌髄腔容積の減少というような 内部変化がある。このような曾牙硬組織や蒾髄腔の年柃 的変化に関する研究は, 人類学的, 解部学的, 法医学的 にはもちろん, 雨科臨床においても極めて重要な問題で ある・

咬耗に関する業績 ${ }^{1-4}$ ，第 2 象牙質についての呼究 5-9)，およびセメント質の添加についての研究10-12) に よってもわかるように堌囹的に咬耗度は增大し，第 2 芜 牙質，セメント質は增加しており，かつ第 2 象牙質の形 成はう蝕, 咬耗, 磨耗などに伴う菌髄防御反広の 1 つ しても起てるものである。

歯䯣腔の形態に関する斫究13-19) としては，墨汁注人 透視法, 真空注入法, $X$ 線年顛などにより計測観察を行 い成果を上げている。また，平野ら（1959)201は，根管 分岐性状を年秢的に調查している，X線写基による電髄

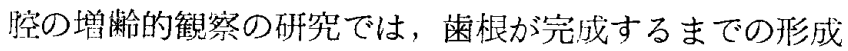

状態について，金田 $(1951)^{211}$ ，山路 $(1958)^{22}$ ，人見 $(1975)^{23}$ があり，比較的正確な年龄推定も可能である と述べている，だが，雬根完成後におけるX線撮影によ る観察では，その笪を知るには不十分である。そこで 実際に歯を切断し計測観察した研究も発表されている. 栗岡 $(1965)^{24}$ ， 久家 $(1969)^{251}$ ，斉藤 $(1970)^{261}$ は， 墨汁浸潤透明梆本による肉眼的観察に加え, 蒾根を 4 部 分に横断し，蒾根の大きさ，根管の大きさ，根管壁の厚 さなどを計测し，その数值から根示数，根管示数，根管: 比を算出し根管の性状を示数值で表現することによって 解剖病理学的検索を行っている。しかし，増粭による苗 䫘腔の減少状態を夹際に計測によって数值で表現した試 みは非常に少なく，田所（1959）2 7 が前䨑部を，菊池

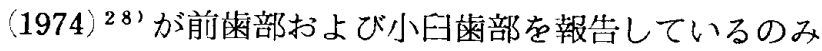
である。

そこで著者は，上下顎の小曰雬について，硬組織の各 部および曾䯠腔の増略的変化を調查するため, 㐪を100 部分に横断しそのうち 4 简所の歯骾腔，エナメル質，象 牙質そしてセメント質の近遠心徍，煩舌径を計測した。 上頢に抠いて単根管の崡のみではなく，2根管菌，2 根蒾についても調査を行った。そして, 計測值と示数值 についての增粭的変化を検討した。 また，近遠心あるい は煩舌方向への増夦に伴う変化の差を知るため幅唇示数 も算出した。乙の結果, 興味ある知見が得られたので報 告する。 


\section{研究材料および方法}

研究材料としては, 歯種, 年路, 性別の明碓な上下類 小曰菌の抜去霜から，う蝕や久損がほとんどない正常歯 后選択した，その歯種別，年秢別総数は表 1 のでとくで ある. 年粭群の分類は例数の関係で表に示すとおり, 10〜19才，20〜39才，40〜49才，50才以上の 4 段階とし た。

Table 1 Number of materials

\begin{tabular}{|c|c|c|c|c|c|}
\hline \multirow{2}{*}{ Age } & \multicolumn{4}{|c|}{ Kind of tooth } & \multirow{2}{*}{ Total } \\
\hline & $\underline{P_{1}}$ & $\underline{\mathrm{P}}_{2}$ & $\overline{\mathbf{P}_{1}}$ & $\overline{\mathrm{P}_{2}}$ & \\
\hline $10-19$ & 20 & 2 & 19 & 4 & 45 \\
\hline $20-39$ & 16 & 15 & 14 & 10 & 55 \\
\hline $40-49$ & 30 & 26 & 31 & 26 & 113 \\
\hline $50-$ & 29 & 26 & 30 & 27 & 112 \\
\hline \multirow{2}{*}{ Total } & 95 & 69 & 94 & 67 & 025 \\
\hline & \multicolumn{2}{|c|}{164} & \multicolumn{2}{|c|}{161} & \\
\hline
\end{tabular}

実験方法は，柬を拔去後10\%ホルマリン溶液に固定 し，アセトンにより脱水したのち，リゴラックで樹脂包 埋を行った。この樹脂包埋を行う前には, 藤田〈(1949) 29) の計測基準に従い雬軸を決定し，䍘軸の投影線を煩 舌面认印記した。また，苗軸を中心として菌を90度回転 させ，近遠心面にも蒾軸の投影線を印記しておいた，包 埋に際しては，歯軸とリゴラック底面が平行になるよう に行い，切断時に横断面が柬軸之直交するように試料板 に装着した。切断には小吸製作所製造の硬組織藻片切断 機 CT-1 型を使用した。次いで, 図 1 左図のごとく, 煩側菌頸線の最下点を通る線を中心に蒾冠部を 4 等分, 歯根部を 6 等分とし, 雨冠 $1 / 2$, 煩側菡頸最下点, 根尖 $2 / 3$
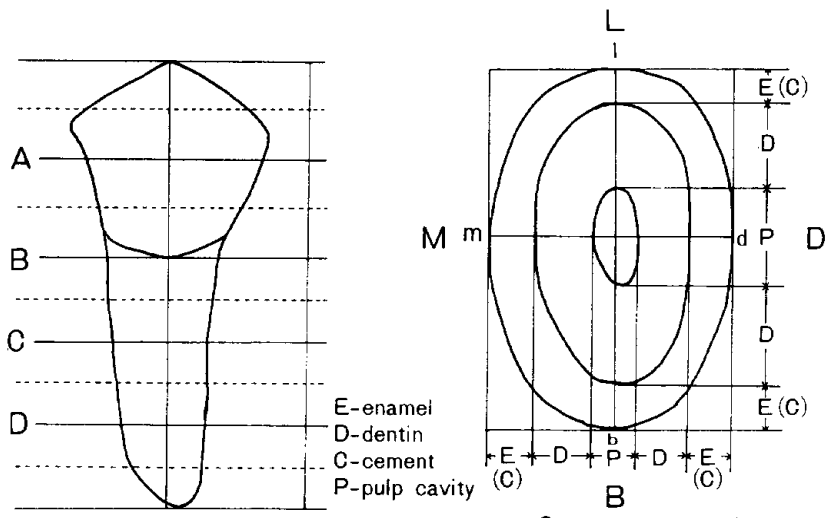

One root canal

Fig. 1 Cutting point and measured section
および根尖 $1 / 3$ の各部で横断したところをそれぞれ A B ・ C・D部とした．切断後はニコンの万能投影機により 10 倍に拉大してトレースを行い，副尺 $1 / 20 \mathrm{~mm}$ つきノギ ス者使用し，上記の $\mathrm{A} \cdot \mathrm{B} \cdot \mathrm{C} \cdot \mathrm{D} の 4$ 䈯所の計測を行 った.

次に横断切片は図 1 右図のように歯軸の投影線と外径 との交点を, b $1, \mathrm{~m}, \mathrm{~d}$ とし, $\mathrm{b}$ と 1 を結ぶ線を $\mathrm{b}$ 1 線 (煩舌径)， $\mathrm{m}$ と d t結ぶ線を $\mathrm{md}$ 線（近遠心径） とした。 ての b 1・m d 線に平行になるようにして, 雬 能有腔および各硬組織の最大径を計測した。ただし，エナ メル質, 象牙質, セメント質では煩側と舌側の厚さの和 を煩舌径, 近心側と遠心側の幅の和を近遠心径とした。 2 根管歯の横断切片では, 煩舌径の計測方法は図 2 左図

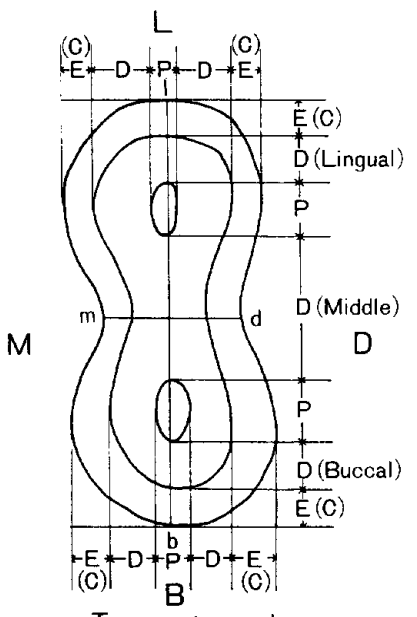

Two root canals

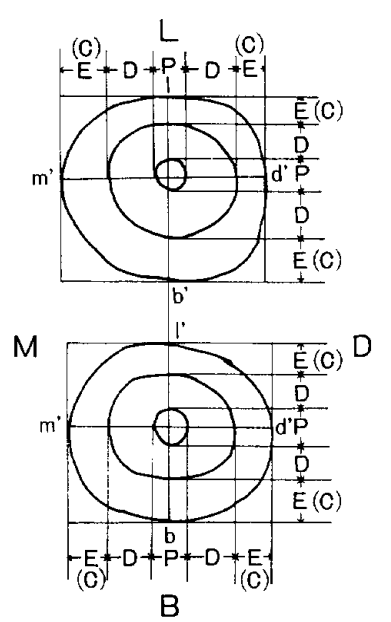

Two roots
Fig. 2 Measured section

のごとく，多徍とセメント質では 1 根管柬の場合と同様 であるが, 象牙質は煩例, 中央部, 舌側の 3 つの和を煩 舌径とした。菌随腔は煩側根管と舌側根管の 2 つに分け て計測した。近遠心径においては, 横断切片を煩側根管 側と舌側根管側に分類し，b 1 線と平行になるようなそ れぞれの最大外径を計測した。2 根雨の場合には，煩側 根側と舌側根側の 2 つに分け，各々の計測を 1 根管歯の 場合に準ずる方法で行った。なお，A部においては橉蹎 腔が存在しないものが大部分であったので, 柬鹃道腔の存 在しない切片のみを対象とした。

歯骮道腔ならびに各硬組織の変化をより客観的にみるた めには，歯の大きさを考慮に人れなければならない，そ てで外径に対する苗䯣腔と各硬組織の割合を表わす示数 值（骮有腔径打よび各硬組織径 $\div$ 外径 $\times 100$ ）を求めた。 そして, 各々をエナメル尔数, 象牙示数, セメント示

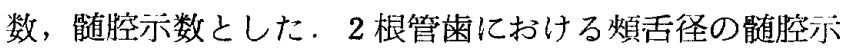


数は，煩側根管と舌側根管の和を外径で徐した割合とし たままた，各部の近遠心あるいは煩舌方向への增秢的変 化をみるために，幅厚示数（近遠心径％煩舌径 $\times 100$ ） を算出した。

各計測値ならびに示数值の統計処理は, 各年齢群別に 平均值 $(\bar{X})$ ，標準偏差値（S．D.）を算出した。そし て平均値の差の検定は $\mathrm{t}$ 検定により，危険率 $5 \%$ 以下で
有意性ありとした。

成

I . 歯の外径, 砸組織各部および雬髄腔の計測值

A. 外径の計測值

1. 上顎第 1 小曰菌

各部の計測結果は, 表 2 の示すと扔りである.A部で

Table 2 Outside diameter on upper first premolar

$(\mathrm{mm})$

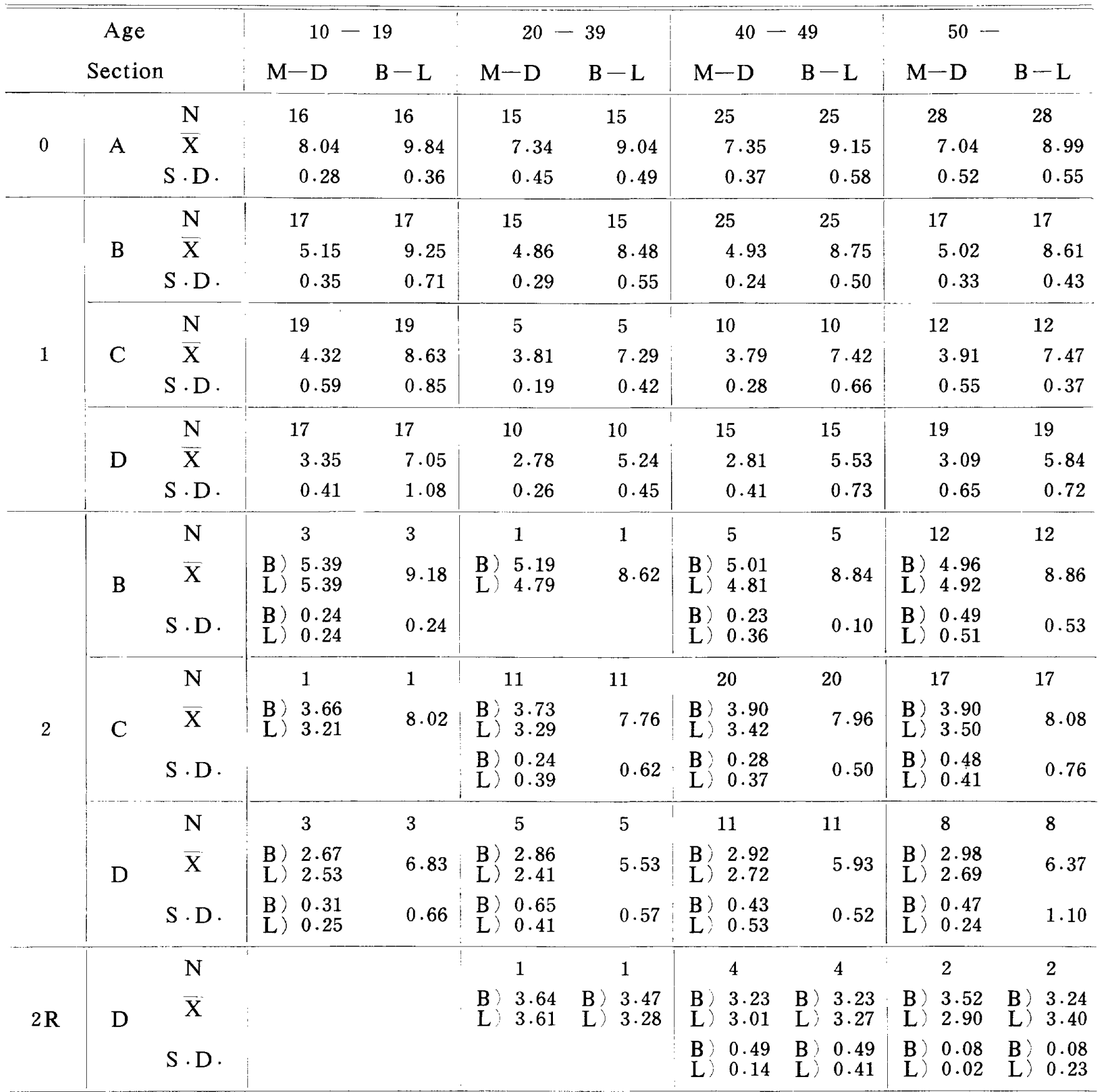

[M-D : Mesio-distal, B-L : Bucco-lingual, B) : Buccal side, L : Lingual side] 0 : Non pulp 1 : One root canal $2:$ Two root canals $2 \mathrm{R}:$ Two roots 
は堌龄に伴い近遠心径，煩舌径ともに減少僋问がみられ た. 特に10才代から20・30才代への変化では近遠心径， 煩舌径ともに $1 \%$ 以下の危険率で，40才代から50才以上 への変化では近遠心径に $5 \%$ 以下の危険率で有意差を認 めた． 1 根管歯でのB・C・D部は，10才代から $20 \cdot 30$ 才代にかけては減少しているが，以後は増柃に従いわず かに増加傾向を示している．10才代から20・30才代への 若年者間での減少には, B・C部での煩舌径, D部の近 遠心径と煩舌径に $1 \%$ 以下の危険率で，B部の近遠心径 には $5 \%$ 以下の危険率で有意差がみられた。 2 根管歯に おいても同様の結果を得たが，有意差がみられたのはD 部の10才代から20・30才代への減少傾向のみであった. 2 根蒾は，上額第 1 小曰雨の 20 - 30才代以降の雬のD部
にのみしか存在せず，少数例ではあるが年粭群相互間の 変化は著明な結果を認めなかった。

2. 上頢第 2 小囦菌

この霜の計測結果は, 表 3 のじとくである，A部の近 還心径，煩舌径においては10才代から20・30才代への減 少傾向が諗められ，1根管歯ではD部の近遠心径の若年 者間での増加傾向， 2 根管䨑はB・D部での 20 ・ 30 才代 から40才代にかけて変化を示していたが，いずれも有意 差は認められなかった。

\section{3. 下顊第 1 小盽歯}

表 4 亿示すとおり，A部は増粭に伴い减少傾向を示 し，B部では10才代から20・30才代の若年者間での減少 を除けば，増榆的には変化はなく，C・D部は若年者間

Table $3 \quad$ Outside diameter on upper second premolar

$(\mathrm{mm})$

\begin{tabular}{|c|c|c|c|c|c|c|c|c|c|c|}
\hline \multirow{2}{*}{\multicolumn{3}{|c|}{$\begin{array}{c}\text { Age } \\
\text { Section }\end{array}$}} & \multirow{2}{*}{\multicolumn{2}{|c|}{$\begin{array}{rl}10-19 \\
M-D & B-L\end{array}$}} & \multicolumn{2}{|c|}{$20-39$} & \multicolumn{2}{|c|}{$40-49$} & \multicolumn{2}{|c|}{$50-$} \\
\hline & & & & & $M-D$ & $B-L$ & $M-D$ & $B-L$ & $M-D$ & $\mathrm{~B}-\mathrm{L}$ \\
\hline \multirow{3}{*}{0} & & $\mathrm{~N}$ & 2 & 2 & 14 & 14 & 26 & 26 & 24 & 24 \\
\hline & A & $\bar{X}$ & 7.25 & 9.34 & 6.76 & 8.87 & 6.84 & 9.01 & 6.78 & 9.13 \\
\hline & & $S \cdot D$. & 0.42 & 0.02 & 0.29 & 0.48 & 0.59 & 0.44 & 0.41 & 0.54 \\
\hline \multirow{9}{*}{1} & & $\mathrm{~N}$ & 2 & 2 & 12 & 12 & 19 & 19 & 18 & 18 \\
\hline & B & $\bar{X}$ & 5.02 & 8.63 & 4.87 & 8.63 & 4.84 & 8.69 & 4.85 & 8.62 \\
\hline & & $S \cdot D$. & 0.11 & 0.20 & 0.29 & 0.44 & 0.24 & 0.57 & 0.38 & 0.65 \\
\hline & & $\mathrm{N}$ & 2 & 2 & 11 & 11 & 17 & 17 & 13 & 13 \\
\hline & C & $\bar{X}$ & 3.98 & 7.63 & 3.76 & 7.54 & 3.76 & 7.52 & 3.82 & 7.71 \\
\hline & & S.D. & 0.28 & 0.24 & 0.25 & 0.68 & 0.36 & 0.66 & 0.45 & 0.49 \\
\hline & & $\mathbf{N}$ & 2 & 2 & 14 & 14 & 21 & 21 & 22 & 22 \\
\hline & $\mathrm{D}$ & $\bar{X}$ & 3.04 & 5.63 & 3.47 & 5.83 & 3.15 & 5.82 & 3.17 & 5.83 \\
\hline & & S.D. & 0.43 & 0.28 & 0.28 & 0.50 & 0.48 & 0.61 & 0.43 & 0.85 \\
\hline \multirow{9}{*}{2} & & $\mathrm{~N}$ & & & 3 & 3 & 7 & 7 & 8 & 8 \\
\hline & B & $\bar{X}$ & & & $\begin{array}{l}\text { B } \\
\text { L) } \\
4.74 \\
4.79\end{array}$ & 8.31 & $\begin{array}{l}\text { B) } \\
\text { L) } \\
5.33 \\
5.33\end{array}$ & 9.37 & $\begin{array}{l}\text { B) } 5.08 \\
\text { L) } 5.09\end{array}$ & 8.99 \\
\hline & & S.D. & & & $\begin{array}{ll}\text { B } & 0.22 \\
\text { L) } & 0.30\end{array}$ & 0.68 & $\begin{array}{ll}\text { B) } & 0.54 \\
\text { L) } & 0.54\end{array}$ & 0.65 & 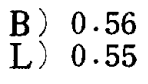 & 0.53 \\
\hline & & $\mathrm{N}$ & & & 4 & 4 & 9 & 9 & 13 & 13 \\
\hline & $\mathrm{C}$ & $\mathrm{X}$ & & & $\begin{array}{l}\text { B) } 3.83 \\
\text { L) } \\
3.37\end{array}$ & $8 \cdot 16$ & $\begin{array}{l}\text { B) } 3.89 \\
\text { L) } 3.66\end{array}$ & 8.06 & $\begin{array}{l}\text { B) } 3.55 \\
\text { L) } 3.42\end{array}$ & 7.91 \\
\hline & & S.D. & & & $\begin{array}{ll}\text { B) } & 0.15 \\
\text { L) } & 0.33\end{array}$ & 0.43 & 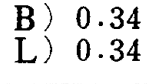 & 0.64 & $\begin{array}{l}\text { B) } \\
\text { L) }\end{array}$ & 0.78 \\
\hline & & $\mathbf{N}$ & & & 1 & 1 & 5 & 5 & 4 & 4 \\
\hline & $\mathrm{D}$ & $\bar{X}$ & & & $\begin{array}{l}\text { B) } 2.84 \\
\text { L) } 2.91\end{array}$ & 6.43 & $\begin{array}{l}\text { B) } \\
\text { L) } \\
2.76\end{array}$ & 5.96 & 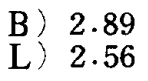 & 5.55 \\
\hline & & S.D. & & & & & $\begin{array}{ll}\text { B) } & 0.44 \\
\text { L) } & 0.38\end{array}$ & 1.42 & $\begin{array}{ll}\text { B) } & 0.66 \\
\text { L) } & 0.39\end{array}$ & 1.12 \\
\hline
\end{tabular}


Table 4 Outside diameter on lower first premolar

$(\mathrm{mm})$

\begin{tabular}{|c|c|c|c|c|c|c|c|c|c|c|}
\hline \multirow{2}{*}{\multicolumn{3}{|c|}{$\begin{array}{c}\text { Age } \\
\text { Section }\end{array}$}} & \multicolumn{2}{|c|}{$10-19$} & \multicolumn{2}{|c|}{$20-39$} & \multicolumn{2}{|c|}{$40-49$} & \multicolumn{2}{|c|}{$50-$} \\
\hline & & & $M-D$ & $B-L$ & $M-D$ & $B-L$ & $M-D$ & $B-L$ & $M-D$ & $B-L$ \\
\hline \multirow{3}{*}{0} & & $\mathrm{~N}$ & 15 & 15 & 12 & 12 & 14 & 14 & 22 & 22 \\
\hline & A & $\bar{X}$ & 7.33 & 7.53 & 7.20 & 7.61 & 6.76 & 7.49 & 6.94 & 7.63 \\
\hline & & $\mathrm{S} \cdot \mathrm{D}$ & 0.44 & 0.60 & 0.53 & 0.49 & 0.55 & 0.70 & 0.46 & 0.44 \\
\hline \multirow{9}{*}{1} & & $\mathrm{~N}$ & 19 & 19 & 14 & 14 & 31 & 31 & 30 & 30 \\
\hline & B & $\bar{X}$ & 5.05 & 7.30 & 4.82 & 6.99 & 4.71 & 6.86 & 4.74 & 6.94 \\
\hline & & $S \cdot D$ & 0.67 & 0.71 & 0.31 & 0.48 & 0.32 & 0.54 & 0.36 & 0.52 \\
\hline & & $\mathrm{N}$ & 19 & 19 & 14 & 14 & 31 & 31 & 30 & 30 \\
\hline & $\mathrm{C}$ & $\mathrm{X}$ & 4.01 & 6.69 & 3.69 & 6.00 & 3.81 & 6.19 & 3.79 & 6.33 \\
\hline & & $S \cdot D$ & 0.32 & 0.66 & 0.32 & 0.43 & 0.44 & 0.78 & 0.33 & 0.47 \\
\hline & & $\mathrm{N}$ & 19 & 19 & 14 & 14 & 31 & 31 & 30 & 30 \\
\hline & $\mathrm{D}$ & $\bar{X}$ & 3.18 & 5.50 & 2.69 & 4.32 & 2.97 & 4.86 & 3.16 & 5.03 \\
\hline & & S.D. & 0.33 & 0.82 & 0.33 & 0.50 & 0.45 & 0.99 & 0.45 & 0.60 \\
\hline
\end{tabular}

Table 5

Outside diameter on lower second premolar

( $\mathrm{mm})$

\begin{tabular}{|c|c|c|c|c|c|c|c|c|c|c|}
\hline \multirow{2}{*}{\multicolumn{3}{|c|}{$\begin{array}{c}\text { Age } \\
\text { Section }\end{array}$}} & \multicolumn{2}{|c|}{$10-19$} & \multicolumn{2}{|c|}{$20-39$} & \multicolumn{2}{|c|}{$40-49$} & \multicolumn{2}{|c|}{$50-$} \\
\hline & & & $M-D$ & $B-L$ & $M-D$ & $B-L$ & $M-D$ & $B-L$ & $M-D$ & $B-L$ \\
\hline \multirow{3}{*}{0} & \multirow{3}{*}{ A } & $\mathrm{N}$ & 4 & 4 & 9 & 9 & 25 & 25 & 25 & 25 \\
\hline & & $\mathrm{X}$ & 7.43 & 8.00 & 7.11 & 7.78 & 7.13 & 7.98 & 7.08 & 8.11 \\
\hline & & S.D. & 0.21 & 0.41 & 0.49 & 0.34 & 0.38 & 0.42 & 0.49 & 0.69 \\
\hline \multirow{9}{*}{1} & \multirow{3}{*}{ B } & $\mathrm{N}$ & 4 & 4 & 10 & 10 & 26 & 26 & 27 & 27 \\
\hline & & $\bar{X}$ & 4.96 & 7.23 & 4.82 & 7.13 & 4.96 & 7.13 & 4.92 & 7.32 \\
\hline & & S.D. & 0.10 & 0.45 & 0.33 & 0.51 & 0.43 & 0.50 & 0.35 & 0.56 \\
\hline & \multirow{3}{*}{$\mathrm{C}$} & $\mathrm{N}$ & 4 & 4 & 10 & 10 & 26 & 26 & 27 & 27 \\
\hline & & $\bar{X}$ & 3.86 & 6.67 & 3.82 & $6 \cdot 10$ & 3.89 & 5.98 & 3.89 & 6.25 \\
\hline & & $S \cdot D$. & 0.25 & 0.27 & 0.56 & 0.75 & 0.36 & 0.60 & 0.40 & 0.69 \\
\hline & \multirow{3}{*}{ D } & $\mathrm{N}$ & 4 & 4 & 10 & 10 & 26 & 26 & 27 & 27 \\
\hline & & $\bar{X}$ & 2.88 & 4.80 & 3.11 & 4.68 & 3.13 & 4.52 & 3.43 & 4.83 \\
\hline & & $S \cdot D$. & 0.10 & 0.22 & 0.51 & 0.78 & 0.45 & 0.69 & 0.79 & 0.91 \\
\hline
\end{tabular}

での変化を除くと，年路に伴い增加傾向を示している. $\mathrm{C}$ 部の煩舌径と $\mathrm{D}$ 部の近遠心徍，煩舌径で10才代と 20 ・ 30 才代との間で $1 \%$ 以下，またA部における近遠心径の $20 \cdot 30$ 才代と 40 才代との䦩に扔いて $5 \%$ 以下の危険率で 有意の差が認められた。

4. 下額第 2 小曰歯

表 5 にみられるごとく各部において年軨相互䦓での著 しい変化はみうけられなかった。

B ．エナメル質の計測值および示数值
計測值の成績は表 6 に，また示数値については表 7 お よび図 3 に示すとおりである。

1. 上影第 1 小臼歯

近遠心径，煩舌径ともに堌龄に伴い減少傾向が著明で ある.特に近遠心径の $10 才$ 代汃ら $20 \cdot 30$ 才代への変化に は $1 \%$ 以下の危険率で有意の差がみられた。エナメル示 数值は, 計測值同様，堌榆的に減少傾问が認められ，熄 歯とともに外径に比べてエナメル質部の減少傾向の胎い ことを示している。 
Table 6

Diameter of enamel

(mm)

\begin{tabular}{|c|c|c|c|c|c|c|c|c|c|c|}
\hline \multirow{2}{*}{\multicolumn{3}{|c|}{$\begin{array}{c}\text { Age } \\
\text { Section }\end{array}$}} & \multicolumn{2}{|c|}{$10-19$} & \multicolumn{2}{|c|}{$20-39$} & \multicolumn{2}{|c|}{$40-49$} & \multicolumn{2}{|c|}{$50-$} \\
\hline & & & $M-D$ & $B-L$ & $M-D$ & $B-L$ & $M-D$ & $B-L$ & $M-D$ & $B-L$ \\
\hline \multirow{12}{*}{0} & & $\mathrm{~N}$ & 16 & 16 & 15 & 15 & 25 & 25 & 28 & 28 \\
\hline & $\underline{P_{1}}$ & $\bar{X}$ & 2.60 & 3.07 & 2.28 & 2.77 & 2.22 & 2.74 & 1.99 & 2.55 \\
\hline & & $S \cdot D$ & 0.20 & 0.88 & 0.35 & 0.44 & 0.35 & 0.86 & 0.40 & 0.59 \\
\hline & & $\mathrm{N}$ & 2 & 2 & 14 & 14 & 26 & 26 & 24 & 24 \\
\hline & $\mathbf{P}_{\underline{2}}$ & $\bar{X}$ & 2.41 & 2.81 & 2.24 & 2.72 & 2.19 & 2.65 & 1.98 & 2.60 \\
\hline & & S.D. & 0.11 & 0.07 & 0.35 & 0.46 & 0.24 & 0.35 & 0.28 & 0.44 \\
\hline & & $\mathrm{N}$ & 15 & 15 & 12 & 12 & 14 & 14 & 22 & 22 \\
\hline & $\overline{P_{1}}$ & $\bar{X}$ & 2.12 & 2.46 & 2.17 & 2.57 & 1.87 & 2.42 & 1.88 & 2.09 \\
\hline & & $S \cdot D$ & 0.24 & 0.18 & 0.25 & 0.51 & 0.47 & 0.51 & 0.33 & 0.37 \\
\hline & & $\mathrm{N}$ & 4 & 4 & 9 & 9 & 25 & 25 & 25 & 25 \\
\hline & $\overline{\mathrm{P}_{2}}$ & $\bar{X}$ & 2.55 & 2.58 & 2.32 & 2.46 & 2.23 & 2.64 & 1.93 & 2.11 \\
\hline & & S.D. & 0.27 & 0.17 & 0.35 & 0.54 & 0.39 & 0.99 & 0.37 & 0.49 \\
\hline
\end{tabular}

Table 7

Enamel index

\begin{tabular}{|c|c|c|c|c|c|c|c|c|c|c|}
\hline \multirow{2}{*}{\multicolumn{3}{|c|}{$\begin{array}{c}\text { Age } \\
\text { Section }\end{array}$}} & \multicolumn{2}{|c|}{$10-19$} & \multicolumn{2}{|c|}{$20-39$} & \multicolumn{2}{|c|}{$40-49$} & \multicolumn{2}{|c|}{$50-$} \\
\hline & & & $M-D$ & $B-L$ & $M-D$ & $B--L$ & $M-D$ & $B-L$ & $M-D$ & $B-I$ \\
\hline \multirow{12}{*}{0} & & $\mathrm{~N}$ & 16 & 16 & 15 & 15 & 25 & 25 & 28 & 28 \\
\hline & $\mathbf{P}_{1}$ & $\mathbf{X}$ & 32.27 & 31.41 & 31.03 & 30.85 & 30.18 & 29.94 & 28.19 & 28.57 \\
\hline & & S.D. & 2.12 & 10.31 & 3.92 & 5.59 & 4.08 & 9.13 & 4.84 & 7.46 \\
\hline & & $\mathrm{N}$ & 2 & 2 & 14 & 14 & 26 & 26 & 24 & 24 \\
\hline & $\mathbf{P}_{2}$ & $X$ & 33.28 & 30.02 & 33.19 & 30.86 & 31.72 & 29.42 & 29.16 & 28.55 \\
\hline & & S $\cdot \mathrm{D}$ & 0.36 & 0.16 & 5.78 & 5.80 & 3.02 & 3.44 & 3.43 & 4.95 \\
\hline & & $\mathrm{N}$ & 15 & 15 & 12 & 12 & 14 & 14 & 22 & 22 \\
\hline & $\overline{P_{1}}$ & $\bar{X}$ & 28.96 & 32.95 & 30.20 & 33.85 & $27 \cdot 49$ & 32.48 & 27.13 & 27.45 \\
\hline & & $S \cdot D$ & 2.89 & 4.09 & 3.20 & $7 \cdot 19$ & 5.74 & 10.36 & 4.36 & 5.15 \\
\hline & & $\mathrm{N}$ & 4 & 4 & 9 & 9 & 25 & 25 & 25 & 25 \\
\hline & $\overline{\mathbf{P}_{2}}$ & $\overline{\mathrm{X}}$ & 34.25 & 32.31 & 32.56 & 31.55 & 31.23 & 33.25 & $27 \cdot 14$ & 26.26 \\
\hline & & S.D. & 2.82 & 3.18 & 3.42 & 6.41 & 4.76 & 13.04 & 4.25 & 6.49 \\
\hline
\end{tabular}

\section{2. 上顥第 2 小曰菌}

計測值は上顥第 1 小四㮀と同様，増粭的に減少傾问が みられるが，著しい変化は認められない，示数值は近遠 心径, 煩舌径とも増㱓に従い減少傾向を認め, 特に近遠 心径での40才代から50才以上へかけては，1\%以下の危 険率で有意の差がみられた。

\section{3. 下頷第 1 小曰歯}

下瀕においても，計測值は全体的に減少傾向をとって いる.10才代から20・30才代にかけての変化では, 近遠
心径, 煩舌徍乙も増加傾向にあったが, 有意の差はなか った。㚘舌径の40才代から50才以上へかけての減少に は，5\%以下の危険率で有意の差が涩められた.エナメ ル示数值は, 計測值と類似した結果となり，10才代から 20 ・30才代への変化はやや増加傾向を示しているが, 全 般的には減少傾向を示している。

4. 下顎第 2 小曰茵

この蒾の計測値は, 近遠心径, 煩舌径ともに増榆に伴 々減少傾向を示しているが，煩舌径の $20 ・ 30$ 才代から 40 


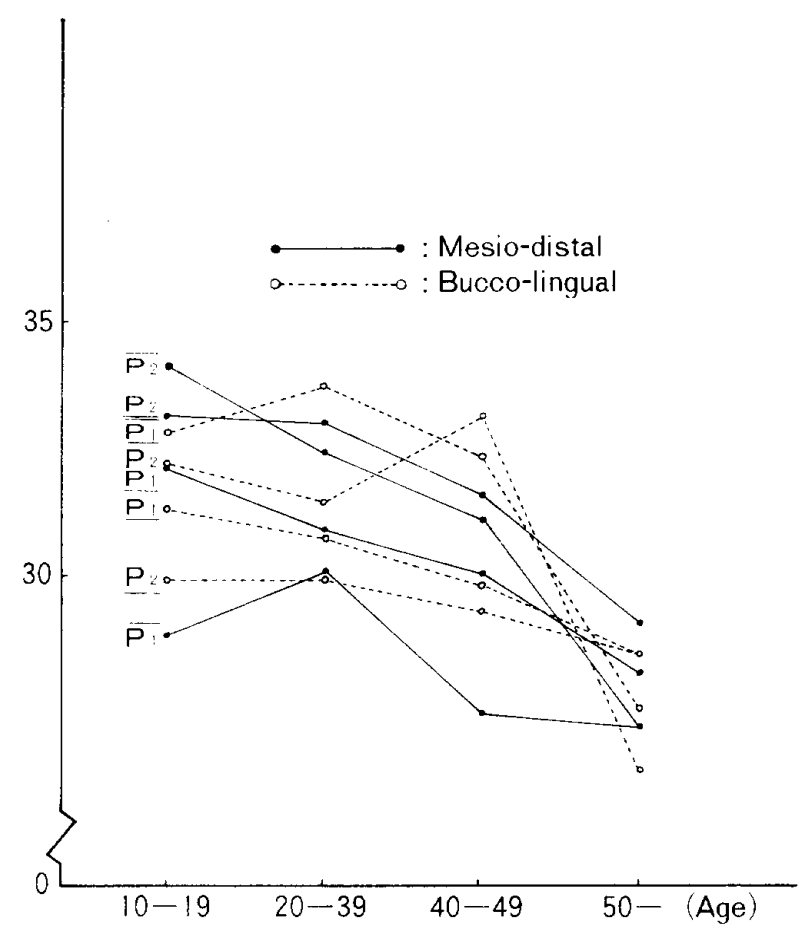

Fig. 3 Enamel index

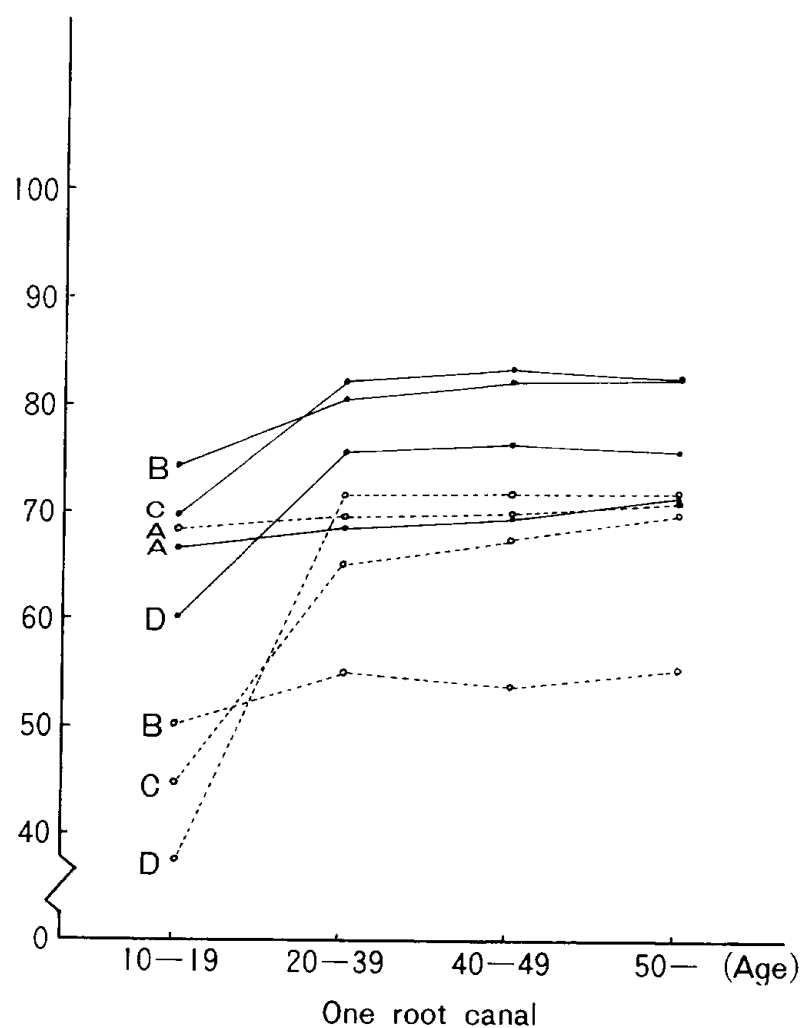

Fig. 4 Dentin index on upper first premolar

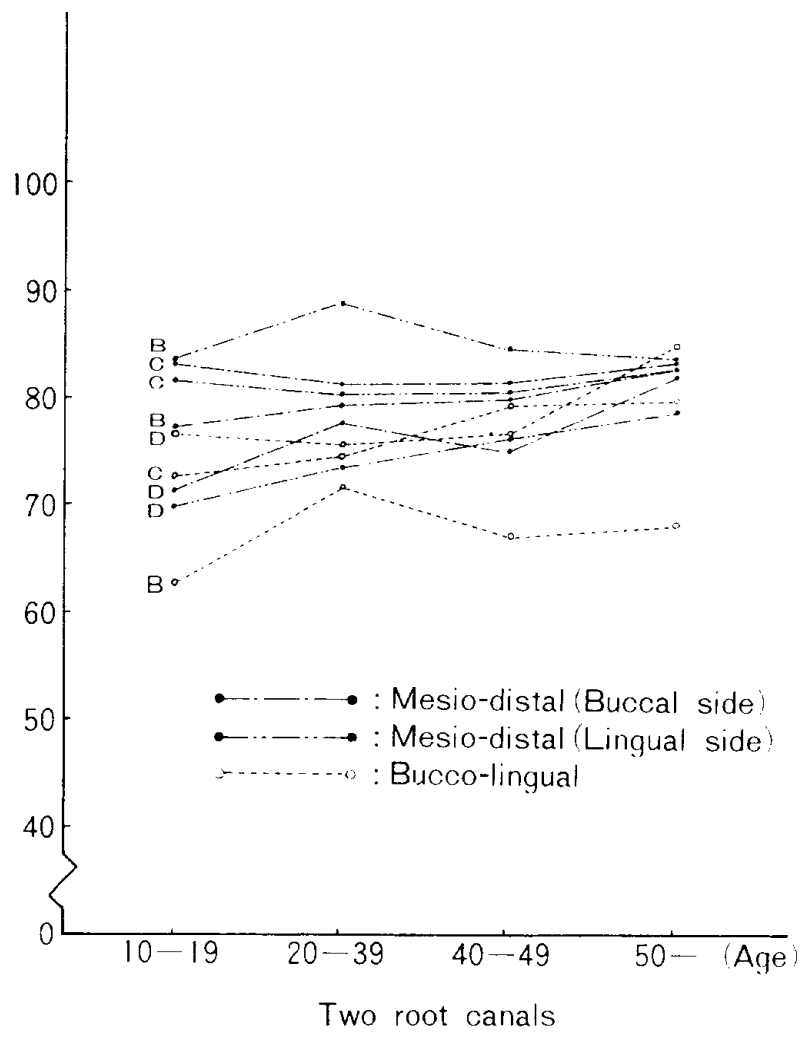

Fig. 5 Dentin index on upper first premolar

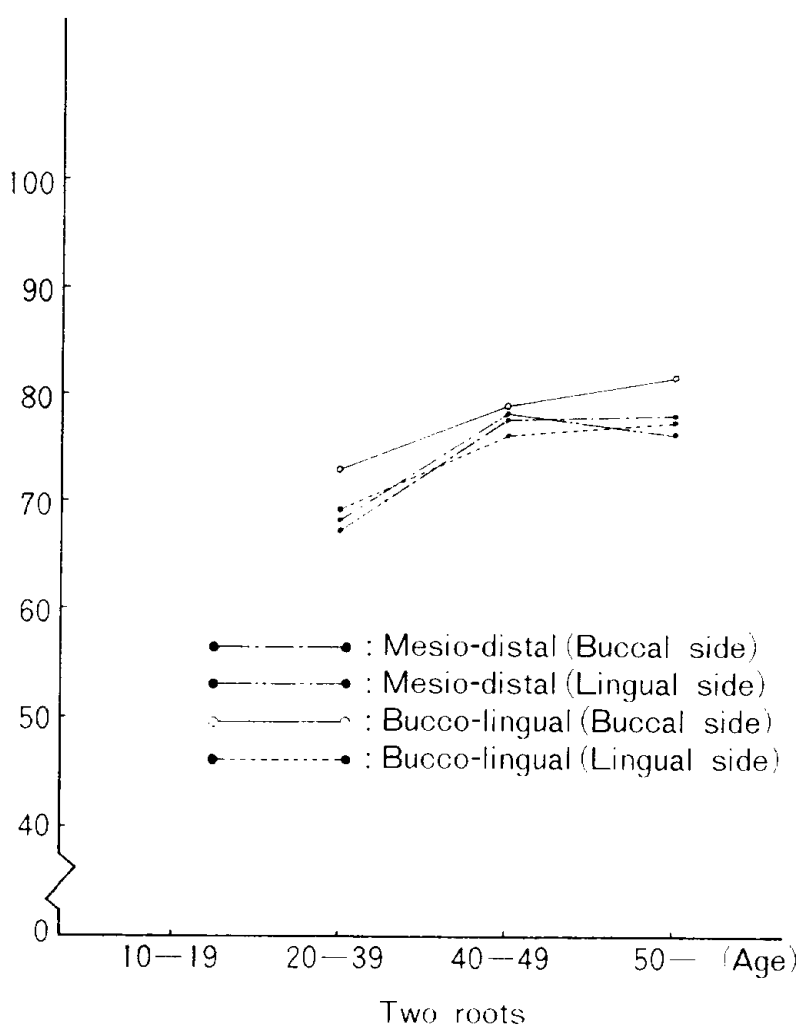

Fig. 6 Dentin index on upper first pre molar 
才代への変化は，他とは反対に増加傾向を示している． しかし，有意の差が認められるのは，煩舌径における40 才代と50才以上との間のみであった．示数值は計測值の 結果同様, 煩舌径での $20 \cdot 30$ 才代から40才代一の堌加傾 向を除いて，一般に減少傾向がみられた。特に40才代と 50才以上との間の近遠心径抢よび煩舌径においては, 有 意の差が認められた。

C. 象牙質の計測値および示数伹

1. 上額第 1 小曰歯
計測結果は，表 8 のでとくであるＡ部は近遠心径， 煩舌径ともに10才代から20・30才代にかけて減少傾向を 示し，特に近遠心径では有意差を示していた。しかし， その他では著しい変化はみられなかった．1根管菊のB 部では, 近遠心径, 煩舌径ともにほとんど変化がみら れず，C・D部では煩舌径に増加傾向が認められ, 殊に 10才代から20・30才代にかけては，1\%以下の危険率で 有意の差がみられた。 2 根管歯では, 各部ともあまり大 きな変化はなかったが，D部の煩舌径で10才代から20・

Table 8 Diameter of dentin on upper first premolar

$(\mathrm{mm})$

\begin{tabular}{|c|c|c|c|c|c|c|c|c|c|c|c|}
\hline \multirow{2}{*}{\multicolumn{3}{|c|}{$\begin{array}{c}\text { Age } \\
\text { Section }\end{array}$}} & \multicolumn{2}{|c|}{$10-19$} & \multicolumn{2}{|c|}{$20-39$} & \multicolumn{2}{|c|}{$40-49$} & \multicolumn{3}{|c|}{$50-$} \\
\hline & & & $M-D$ & $B-L$ & $M-D$ & $B-L$ & $M-D$ & $B-L$ & $M-D$ & & $3-L$ \\
\hline \multirow{3}{*}{0} & & $N$ & 16 & 16 & 15 & 15 & 25 & 25 & 28 & & 28 \\
\hline & A & $\bar{X}$ & 5.37 & 6.75 & 5.02 & 6.30 & 5.10 & 6.39 & 5.02 & & 6.42 \\
\hline & & $S \cdot D$ & 0.38 & 1.12 & 0.35 & 0.72 & 0.31 & 0.93 & 0.41 & & 0.86 \\
\hline \multirow{9}{*}{1} & & $N$ & 17 & 17 & 15 & 15 & 25 & 25 & 17 & & 17 \\
\hline & B & $\bar{X}$ & 3.83 & 4.61 & 3.91 & 4.68 & 4.05 & 4.71 & 4.14 & & 4.77 \\
\hline & & $S \cdot D$ & 0.26 & 0.31 & 0.23 & 0.56 & 0.21 & 0.40 & 0.33 & & 0.47 \\
\hline & & $\mathrm{N}$ & 19 & 19 & 5 & 5 & 10 & 10 & 12 & & 12 \\
\hline & $\mathrm{C}$ & $\bar{X}$ & 3.00 & 3.84 & 3.14 & 4.75 & 3.17 & 4.98 & 3.23 & & 5.23 \\
\hline & & $S \cdot D$ & 0.37 & 0.49 & 0.17 & 0.21 & 0.28 & 0.51 & 0.42 & & 0.88 \\
\hline & \multirow{3}{*}{ D } & $\mathrm{N}$ & 17 & 17 & 10 & 10 & 15 & 15 & 19 & & 19 \\
\hline & & $\bar{X}$ & 2.01 & 2.56 & 2.11 & 3.75 & 2.15 & 3.97 & \multirow{2}{*}{\multicolumn{2}{|c|}{$\begin{array}{l}2.27 \\
0.41\end{array}$}} & 4.20 \\
\hline & & S.D. & 0.43 & 0.83 & 0.24 & 0.42 & 0.39 & 0.67 & & & 0.68 \\
\hline \multirow{9}{*}{2} & \multirow{3}{*}{ B } & $\mathrm{N}$ & 3 & 3 & \multirow{3}{*}{ 3) $\begin{array}{l}4.11 \\
4.26\end{array}$} & 1 & 5 & 5 & 12 & & 12 \\
\hline & & $\bar{X}$ & $\begin{array}{ll}\text { B) } & 4.16 \\
\text { L) } & 4.36\end{array}$ & 5.77 & & \multirow[t]{2}{*}{6.18} & $\begin{array}{l}\text { B) } \\
\text { L) } \\
4.06 \\
\end{array}$ & 5.92 & $\begin{array}{l}\text { B) } 4.07 \\
\text { L) } 4.11\end{array}$ & & 6.01 \\
\hline & & S.D. & 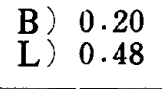 & 0.25 & & & $\begin{array}{l}\text { B) } 0.33 \\
\text { L) } 0.29\end{array}$ & 0.49 & $\begin{array}{ll}\text { B) } & 0.22 \\
\text { L) } & 0.41\end{array}$ & & 0.50 \\
\hline & \multirow{3}{*}{ C } & $\mathrm{N}$ & \multirow{3}{*}{$\begin{array}{l}1 \\
3.05 \\
2.63\end{array}$} & 1 & \multirow{2}{*}{ B) 11} & 11 & 20 & 20 & 17 & \multicolumn{2}{|r|}{17} \\
\hline & & $\bar{X}$ & & \multirow[t]{2}{*}{5.83} & & 5.78 & $\begin{array}{l}\text { B) } \begin{array}{l}3.18 \\
\text { L) }\end{array} 2.75\end{array}$ & 6.31 & $\begin{array}{l}\text { B) } 3.23 \\
\text { L) } 2.88\end{array}$ & & 6.44 \\
\hline & & S.D. & & & $\begin{array}{ll}\text { B) } & 0.21 \\
\text { L) } & 0.28\end{array}$ & 0.83 & $\begin{array}{ll}\text { B) } & 0.25 \\
\text { L) } & 0.27\end{array}$ & 0.62 & $\begin{array}{ll}\text { B) } & 0.31 \\
\text { L) } & 0.31\end{array}$ & & 0.67 \\
\hline & \multirow{3}{*}{$\mathrm{D}$} & $\mathrm{N}$ & 3 & 3 & 5 & 5 & 11 & 11 & 8 & & 8 \\
\hline & & $\bar{X}$ & $\begin{array}{ll}\text { B) } & 1.91 \\
\text { L) } & 1.77\end{array}$ & 5.25 & $\begin{array}{l}\text { B) } 2.23 \\
\text { L) } 1.80\end{array}$ & $4 \cdot 17$ & 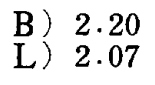 & 4.54 & $\begin{array}{l}\text { B) } 2.42 \\
\text { L) } 2.12\end{array}$ & & 5.40 \\
\hline & & S.D. & 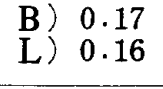 & 0.21 & $\begin{array}{ll}\text { B) } & 0.32 \\
\text { L) } & 0.52 \\
\end{array}$ & 0.38 & 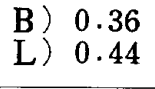 & 0.67 & $\begin{array}{ll}\text { B) } & 0.40 \\
\text { L) } & 0.19\end{array}$ & & 0.98 \\
\hline \multirow{3}{*}{$2 \mathrm{R}$} & \multirow{3}{*}{ D } & $\mathrm{N}$ & & & 1 & 1 & 4 & 4 & 2 & & 2 \\
\hline & & $\bar{X}$ & & & $\begin{array}{l}\text { B) } 2.49 \\
\text { L) } 2.50\end{array}$ & $\begin{array}{l}\text { B ) } 2.57 \\
\text { L) } 2.30\end{array}$ & $\begin{array}{l}\text { B) } \\
\text { L) } \\
2.64 \\
\end{array}$ & $\begin{array}{l}\text { B) } 2.58 \\
\text { L) } 2.52\end{array}$ & $\begin{array}{l}\text { B) } 2.77 \\
\text { L) } 2.25\end{array}$ & $\begin{array}{l}\text { B) } \\
\text { L) }\end{array}$ & $\begin{array}{l}2.68 \\
2.66\end{array}$ \\
\hline & & $S \cdot D$ & & & & & 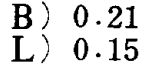 & $\begin{array}{ll}\text { B) } & 0.43 \\
\text { L) } & 0.34\end{array}$ & $\begin{array}{l}\text { B) } 0.01 \\
\text { L) } 0.01\end{array}$ & $\begin{array}{l}\text { B) } \\
\text { L) }\end{array}$ & $\begin{array}{l}0.16 \\
0.05\end{array}$ \\
\hline
\end{tabular}


30 才代一の減少傾向に $1 \%$ 以下の危険率で, また 40 才代 から50才以上への増加傾向に $5 \%$ 以下の危険率で有意の 差が諗められた。 2 根歯の場合は, 近遠心径, 煩舌径と もに変化はほとんどみられなかった。

象牙示数值は，表 9 および図 $4 ， 5 ， 6$ のとおりであ る. 歯髄腔の存在しないA部では増齿的な変化はあまり みられなかったが，1根管歯のB・C・D部では，増栯 に伴う増加傾向を示し, 近遠心径, 煩舌径の10才代汃ら 20 ・30才代への変化には，1\%以下の水準で有意の差が
䜑められた。(なお， 1 根管菌のグラフの中にA 部は念 まれている。） 2 根管粷では，全体的に増㱓に伴い増加 傾向にあり，D部の近遠心径の煩側部および煩舌径にお いて，ともに40才代から50才以上へかけて有意の差がみ られた。 2 根蒾は, 增踰的に增加傾向が認められるが， 有意の差のあるものはみられなかった。

\section{2 . 上顎第 2 小目歯}

表10が, この㐘の計測值の結果である、A部では, 著 しい変化は羿められない. 1 根管雬での $\mathrm{B} ・ \mathrm{C} \cdot \mathrm{D}$ 部

Table 9 Dentin index on upper first premolar

\begin{tabular}{|c|c|c|c|c|c|c|c|c|c|c|}
\hline \multirow{2}{*}{\multicolumn{3}{|c|}{$\begin{array}{c}\text { Age } \\
\text { Section }\end{array}$}} & \multicolumn{2}{|c|}{$10-19$} & \multicolumn{2}{|c|}{$20-39$} & \multicolumn{2}{|c|}{$40-49$} & \multicolumn{2}{|c|}{$50-$} \\
\hline & & & $M-D$ & $B-L$ & $M-D$ & $B-L$ & $M-D$ & $B-L$ & $M-D$ & $B-L$ \\
\hline \multirow{3}{*}{0} & \multirow{3}{*}{ A } & $\mathrm{N}$ & 16 & 16 & 15 & 15 & 25 & & 28 & 28 \\
\hline & & $\overline{\mathrm{X}}$ & 66.76 & 68.44 & 68.50 & 69.58 & 69.43 & 69.82 & 71.45 & 71.13 \\
\hline & & $\mathrm{S} \cdot \mathrm{D}$ & 3.38 & 10.31 & 3.99 & 5.64 & 3.84 & 9.08 & 4.80 & 7.39 \\
\hline \multirow{9}{*}{1} & \multirow{3}{*}{$\mathrm{B}$} & $\mathrm{N}$ & 17 & 17 & 15 & 15 & 25 & 25 & 17 & 17 \\
\hline & & $\overline{\mathrm{X}}$ & 74.43 & 50.03 & 80.63 & 55.29 & 82.39 & 53.91 & 82.57 & 55.43 \\
\hline & & $S \cdot D$ & 3.56 & 3.44 & 3.81 & 6.53 & 3.26 & 4.60 & 4.53 & 5.88 \\
\hline & \multirow{3}{*}{ C } & $\mathrm{N}$ & 19 & 19 & 5 & 5 & 10 & 10 & 12 & 12 \\
\hline & & $\bar{X}$ & 69.79 & 44.93 & 82.48 & 65.32 & 83.52 & 67.45 & 82.68 & 69.97 \\
\hline & & S.D. & $7 \cdot 19$ & 8.48 & 3.47 & 4.30 & 2.24 & 7.31 & 4.73 & 10.47 \\
\hline & \multirow{3}{*}{$\mathrm{D}$} & $\mathrm{N}$ & 17 & 17 & 10 & 10 & 15 & 15 & 19 & 19 \\
\hline & & $\bar{X}$ & 60.25 & 37.67 & 75.74 & 71.54 & 76.37 & 71.95 & 75.96 & 71.94 \\
\hline & & $\mathrm{S} \cdot \mathrm{D}$ & 10.85 & 14.06 & 4.61 & 4.87 & 4.02 & 8.66 & 9.42 & 8.11 \\
\hline \multirow{9}{*}{2} & \multirow{3}{*}{ B } & $\mathrm{N}$ & 3 & 3 & 1 & 1 & 5 & 5 & 12 & 12 \\
\hline & & $\mathrm{X}$ & $\begin{array}{l}\text { B) } 77.22 \\
\text { L) } 83.56\end{array}$ & 62.87 & $\begin{array}{l}\text { B) } 79.09 \\
\text { L) } 88.94\end{array}$ & 71.64 & $\begin{array}{l}\text { B) } 79.66 \\
\text { L) } 84.64\end{array}$ & 67.04 & $\begin{array}{l}\text { B) } 82.52 \\
\text { L) } 83.58\end{array}$ & 68.01 \\
\hline & & $\mathrm{S} \cdot \mathrm{D}$ & $\begin{array}{l}\text { B ) } 0.29 \\
\text { L) } 4.47\end{array}$ & 2.37 & & & $\begin{array}{l}\text { B) } 4.24 \\
\text { L) } 4.49\end{array}$ & 5.61 & $\begin{array}{l}\text { B) } 5.38 \\
\text { L) } 5.39\end{array}$ & 6.44 \\
\hline & \multirow{3}{*}{$\mathrm{C}$} & $\mathrm{N}$ & 1 & 1 & 11 & 11 & 20 & 20 & 17 & 17 \\
\hline & & $\bar{X}$ & $\begin{array}{l}\text { B) } 83.45 \\
\text { L) } 81.78\end{array}$ & 72.61 & $\begin{array}{l}\text { B) } 81.18 \\
\text { L) } 80.42\end{array}$ & 74.60 & $\begin{array}{l}\text { B) } 81.43 \\
\text { L) } 80.50\end{array}$ & 79.26 & $\begin{array}{l}\text { B) } 83.16 \\
\text { L) } 82.50\end{array}$ & 79.77 \\
\hline & & $S \cdot D$ & & & $\begin{array}{l}\text { B) } 1.92 \\
\text { L) } 2.03\end{array}$ & 6.60 & $\begin{array}{l}\text { B) } 2.52 \\
\text { L) } 3.32\end{array}$ & 5.85 & 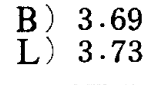 & 6.09 \\
\hline & \multirow{3}{*}{$\mathrm{D}$} & $N$ & 3 & 3 & 5 & 5 & 11 & 11 & 8 & 8 \\
\hline & & $\bar{X}$ & $\begin{array}{l}\text { B) } 71.43 \\
\text { L) } 70.01\end{array}$ & 76.77 & $\begin{array}{l}\text { B) } 77.55 \\
\text { L) } 73.65\end{array}$ & 75.63 & $\begin{array}{l}\text { B) } 75.06 \\
\text { L) } 76.32\end{array}$ & 76.43 & 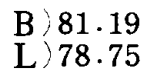 & 84.77 \\
\hline & & $\mathrm{S} \cdot \mathrm{D}$ & $\begin{array}{l}\text { B) } 2.74 \\
\text { L) } 1.59\end{array}$ & 2.88 & $\begin{array}{l}\text { B) } \\
4.10 \\
\text { L) } 9.47\end{array}$ & 6.12 & $\begin{array}{l}\text { B) } \\
\text { L) } \\
6.46 \\
\end{array}$ & 7.82 & $\begin{array}{l}\text { B) } 3.80 \\
\text { L) } 3.83\end{array}$ & 2.71 \\
\hline \multirow{3}{*}{$2 \mathrm{R}$} & \multirow{3}{*}{$\mathrm{D}$} & $\mathrm{N}$ & & & 1 & 1 & 4 & 4 & 2 & 2 \\
\hline & & $\overline{\mathrm{X}}$ & & & $\begin{array}{l}\text { B } 68.27 \\
\text { L } 69.25\end{array}$ & $\begin{array}{l}\text { B) } 73.92 \\
\text { L } 70.08\end{array}$ & $\begin{array}{l}\text { B ) } 78.67 \\
\text { L) } 79.21\end{array}$ & $\begin{array}{l}\text { B) } 79.83 \\
\text { L) } 77.08\end{array}$ & $\begin{array}{l}\text { B) } 78.65 \\
\text { L) } 77.44\end{array}$ & $\begin{array}{l}\text { B) } 82.53 \\
\text { L) } 78.31\end{array}$ \\
\hline & & $S \cdot D$ & & & & & 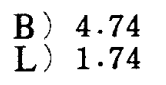 & $\begin{array}{ll}\text { B) } & 3.79 \\
\text { L) } & 0.81\end{array}$ & $\begin{array}{l}\text { B) } 1.41 \\
\text { L) } 0.29\end{array}$ & $\begin{array}{l}\text { B) } 2.86 \\
\text { L) } 3.83\end{array}$ \\
\hline
\end{tabular}


Table 10 Diameter of dentin on upper second premolar

(mm)

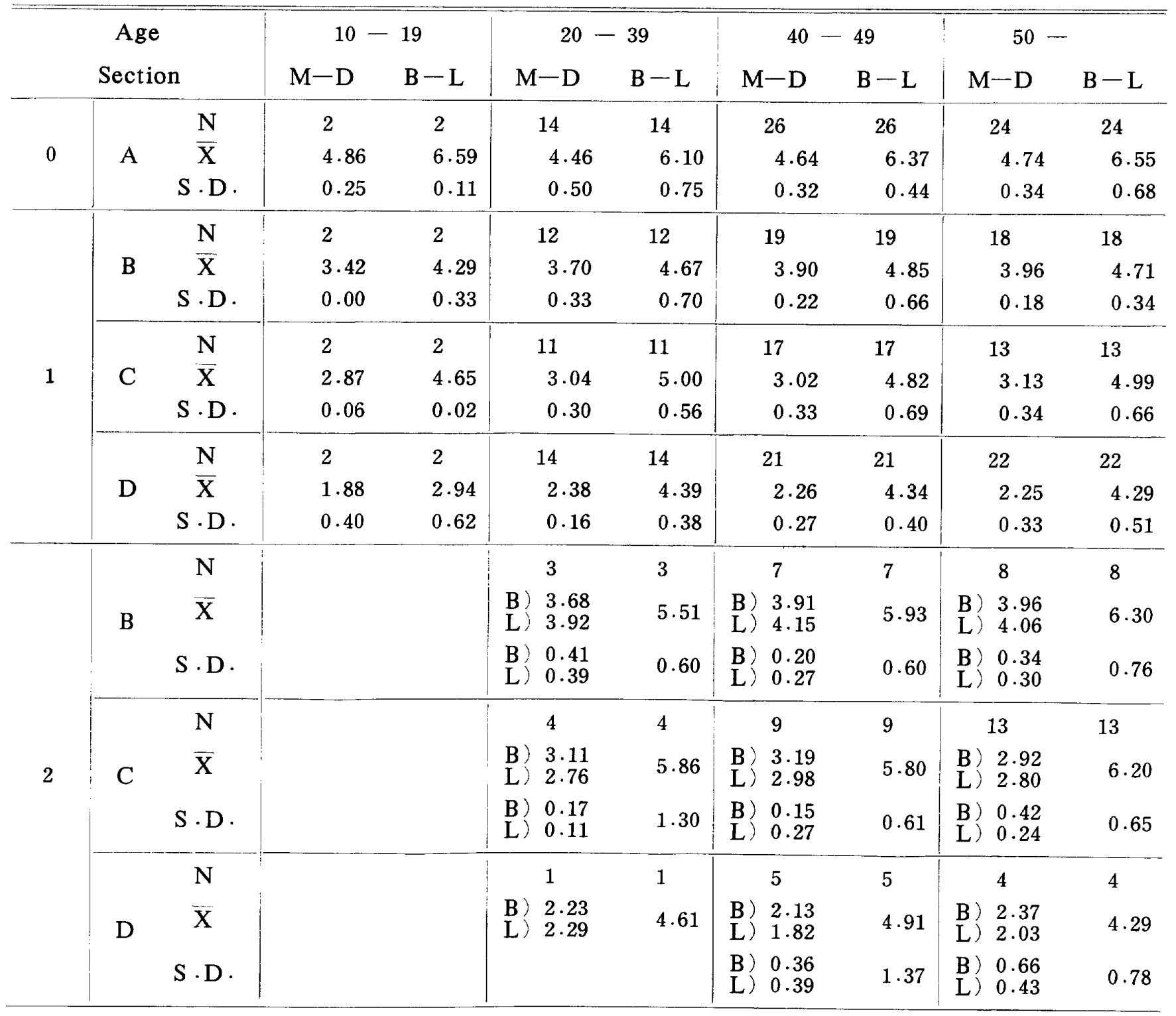

は, 増㱓に伴い増加を示し，特に根尖に近いD部では顕 著で, 近遠心径, 煩舌径とむに10才代から $20 \cdot 30 才$ 才代の 若年者間において，1\%以下の水準で有意の差が認めら れた. 2 根管菌でも増龄的に増加がみられた。

示数值は, 表11および図 $7 ， 8$ に示すとおりである. A 部では，増齢的に著明な変化は認められなかった，1

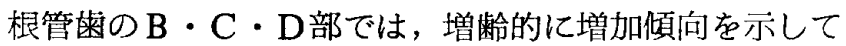
いるが，特にC・D部の近遠心径では，5\%以下で，D 部の煩舌径では，1\%以下でともに10才代から20・30才 代にかけての変化に有意の差が存在した。2根管歯で は，大きな変化はみられなかったが，C部の煩舌径にお いては，40才代から50才以上への年粭群間に，5\%以下 の危険率の有意差で堌加傾向が認められた。

\section{3. 下顎第 1 小曰㮀}

計測值は，表12に示すとおりであるＡＡ部の近遠心 径，B 部の煩舌径は，増粭に伴う変化はあまりみられな かったが，他の部位では増加傾向が認められた。殊に，

$\mathrm{C} \cdot \mathrm{D}$ 部の煩舌径の増加は顕著で・10才代から20・30才代 にかけて，1\%以下の危険率で有意の差が認められた。

象牙示数值の成績は，表13および図 9 亿示すとおりで ある.A部の煩舌径の 40 才代と50才以上との間では， 5 \%以下の危険率で有意差がみられたが，10才代から40才 代にかけては，著しい変化は示さなかった，他の部で は，10才代から20・30才代への若年者閒での増加が著明 で， B 部の近遠心径ならびにC・D部の近遠心径と煩舌 径には， $1 \%$ 以下の水準で有意の差が認められた，20・ 
Table 11 Dentin index on upper second premolar

\begin{tabular}{|c|c|c|c|c|c|c|c|c|c|c|}
\hline \multirow{2}{*}{\multicolumn{3}{|c|}{$\begin{array}{c}\text { Age } \\
\text { Section }\end{array}$}} & \multicolumn{2}{|c|}{$10-19$} & \multicolumn{2}{|c|}{$20-39$} & \multicolumn{2}{|c|}{$40-49$} & \multicolumn{2}{|c|}{$50-$} \\
\hline & & & $M-D$ & $B-L$ & $M-D$ & $B-L$ & $M-D$ & $B-L$ & $M-D$ & $B-L$ \\
\hline \multirow{3}{*}{0} & \multirow{3}{*}{ A } & $\mathrm{N}$ & 2 & 2 & 14 & 14 & 26 & 26 & 24 & 24 \\
\hline & & $\bar{X}$ & 67.09 & 70.54 & 65.86 & 68.68 & 67.08 & 70.73 & 69.97 & 71.64 \\
\hline & & S.D. & 0.35 & 1.03 & 5.76 & 5.72 & 3.27 & 3.74 & 3.87 & 4.92 \\
\hline \multirow{9}{*}{1} & \multirow{3}{*}{ B } & $\mathrm{N}$ & 2 & 2 & 12 & 12 & 19 & 19 & 18 & 18 \\
\hline & & $\bar{X}$ & 68.21 & 49.71 & 76.40 & 54.21 & 80.47 & 55.85 & 81.79 & 54.77 \\
\hline & & S.D. & 1.44 & 2.72 & 8.35 & 8.21 & 2.62 & 7.57 & 4.55 & 4.39 \\
\hline & \multirow{3}{*}{$\mathrm{C}$} & $\mathrm{N}$ & 2 & 2 & 11 & 11 & 17 & 17 & 13 & 13 \\
\hline & & $\bar{X}$ & 72.24 & 60.97 & 80.67 & 68.73 & 80.19 & 64.60 & 82.07 & 65.04 \\
\hline & & $\mathrm{S} \cdot \mathrm{D}$. & 3.54 & 2.18 & 4.55 & 8.75 & 3.68 & 11.04 & 3.55 & 9.63 \\
\hline & \multirow{3}{*}{$\mathrm{D}$} & $\mathbf{N}$ & 2 & 2 & 14 & 14 & 21 & 21 & 22 & 22 \\
\hline & & $\bar{X}$ & 61.55 & 52.48 & 73.46 & 75.48 & 72.29 & 74.73 & 71.15 & 73.67 \\
\hline & & $S \cdot D$. & 4.42 & 13.68 & 5.49 & 4.77 & 5.70 & 5.06 & 8.15 & 5.45 \\
\hline \multirow{9}{*}{2} & \multirow{3}{*}{ B } & $\mathbf{N}$ & & & 3 & 3 & 7 & 7 & 8 & 8 \\
\hline & & $\bar{X}$ & & & $\begin{array}{l}\text { B) } 77.54 \\
\text { L) } 81.84\end{array}$ & 66.22 & $\begin{array}{l}\text { B) } 73.91 \\
\text { L } \\
78.16\end{array}$ & 63.38 & $\begin{array}{l}\text { B) } 78.35 \\
\text { L } \\
80.27\end{array}$ & 70.08 \\
\hline & & S.D. & & & $\begin{array}{l}\text { B) } 5.35 \\
\text { L) } 4.36\end{array}$ & 2.86 & $\begin{array}{l}\text { B) } 6.83 \\
\text { L) } 5.73\end{array}$ & 6.31 & $\begin{array}{l}\text { B) } 7.88 \\
\text { L) } 6.79\end{array}$ & 7.19 \\
\hline & \multirow{3}{*}{$\mathrm{C}$} & $\mathrm{N}$ & & & 4 & 4 & 9 & 9 & 13 & 13 \\
\hline & & $\overline{\mathrm{X}}$ & & & $\begin{array}{l}\text { B) } 81.20 \\
\text { L) } 79.32\end{array}$ & 71.26 & $\begin{array}{l}\text { B) } 82.33 \\
\text { L) } 81.40\end{array}$ & 71.95 & $\begin{array}{l}\text { B) } 82.17 \\
\text { L) } 81.89\end{array}$ & 78.64 \\
\hline & & $S \cdot D$ & & & 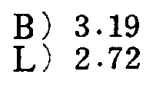 & 12.54 & $\begin{array}{l}\text { B) } 4.38 \\
\text { L) } 4.13\end{array}$ & 5.72 & $\begin{array}{l}\text { B) } 3.30 \\
\text { L) } 2.79\end{array}$ & 5.73 \\
\hline & \multirow{3}{*}{$\mathrm{D}$} & $\mathrm{N}$ & & & 1 & 1 & 5 & 5 & 4 & 4 \\
\hline & & $\overline{\mathrm{X}}$ & & & $\begin{array}{l}\text { B) } 78.66 \\
\text { L) } 78.69\end{array}$ & 71.54 & $\begin{array}{l}\text { B) } 77.20 \\
\text { L) } 74.88\end{array}$ & 81.77 & $\begin{array}{l}\text { B) } 81.57 \\
\text { L) } 79.21\end{array}$ & 77.63 \\
\hline & & $S \cdot D$ & & & & & $\begin{array}{l}\text { B) } 1.59 \\
\text { L) } 5.10\end{array}$ & 3.19 & $\begin{array}{l}\text { B) } 7.78 \\
\text { L) } 9.59\end{array}$ & 4.16 \\
\hline
\end{tabular}

30才代以降の増齢変化においては，わずかに増加傾向が みられた。

\section{4. 下顎第 2 小曰歯}

この歯の計測值は，表14のでとくである．A部では， 10才代から40才代まではほとんど変化がないが，40才代 から50才以上へは增加傾向か:示され，煩舌径では $5 \%$ 以 下の危険率で有意差が諗められた， B・C・D部は，増 秢的に増加を示し，殊にD部の煩舌径では，10才代から 20 ・30才代への若年者間に扔いて，1\%以下の危険率で 有意差がみられた。

象牙示数值は，表15および図10に示すとおりである. 菌冠部であるA部では，40才以降において，近遠心径お よび煩舌径に有意の差がみられた，歯頸部を横断した B
部は, 煩舌径よりも近遠心径の方が増加傾向が著しく, 10 才代と 20 ・30才代との間で $1 \%$ 以下，40才代と50才以 上との間で $5 \%$ 以下の危険率で有意差が認められた。C 部では, 近遠心径の $10 才$ 才代と 20 ・30才代との間で $1 \%$ 以 下，40才代と50才以上との間で $5 \%$ ○下，また煩舌径の $10 才$ 代と $20 \cdot 30$ 才代との間で $5 \%$ 以下で有意の差が認め られた。根尖部に近いD部での変化は，10才代から20・ 30才代にかけて増加傾向が著しく, 近遠心径, 煩舌径と もに $1 \%$ 以下の仜険率で有意性がみられた．20・30才代 以降の各年齢群相互間には，大きな変化はなかった。

D. セメント質の計測值および示数值

1. 上頻第 1 小白歯

上䫑小曰歯の計測值は, 表16の示すとおりである， 1 


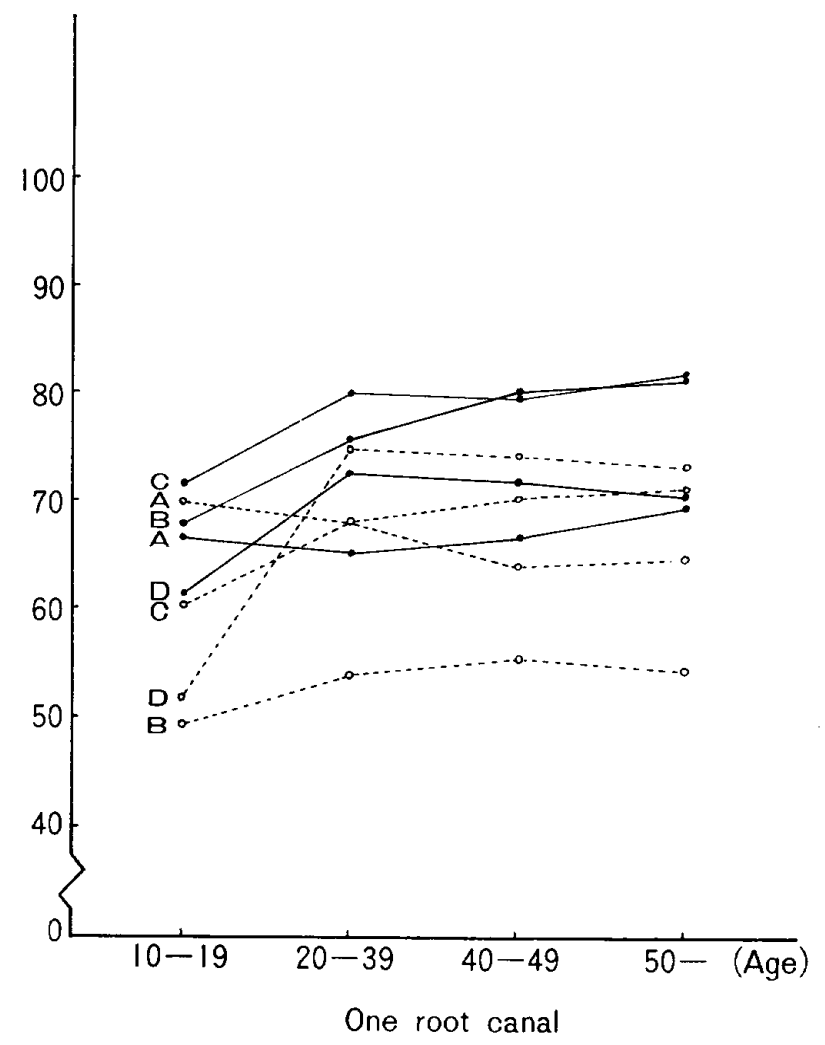

Fig. 7 Dentin index on upper second premolar

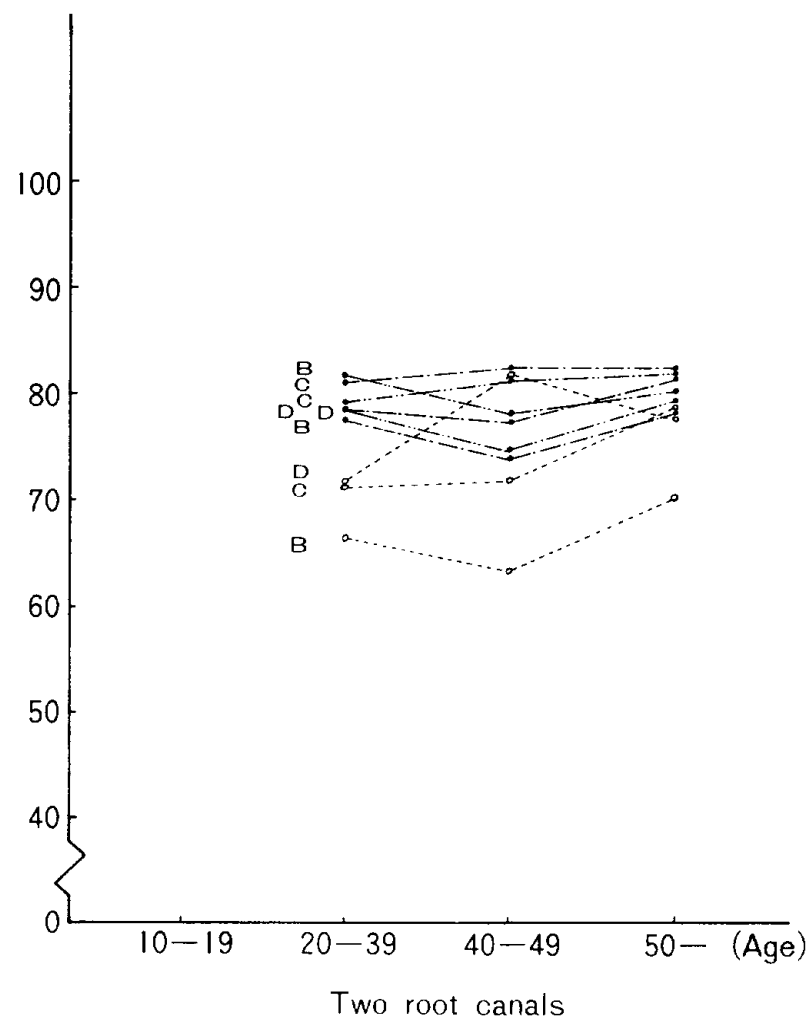

Fig. 8 Dentin index on upper second premolar

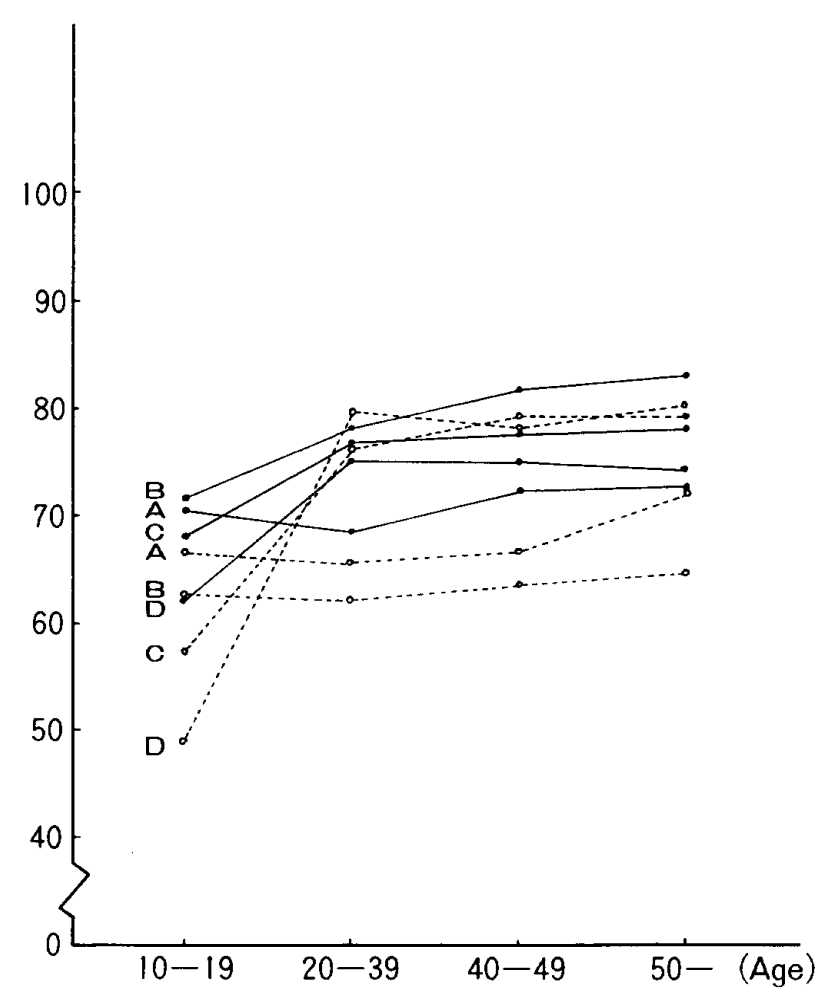

Fig. 9 Dentin index on lower first premolar

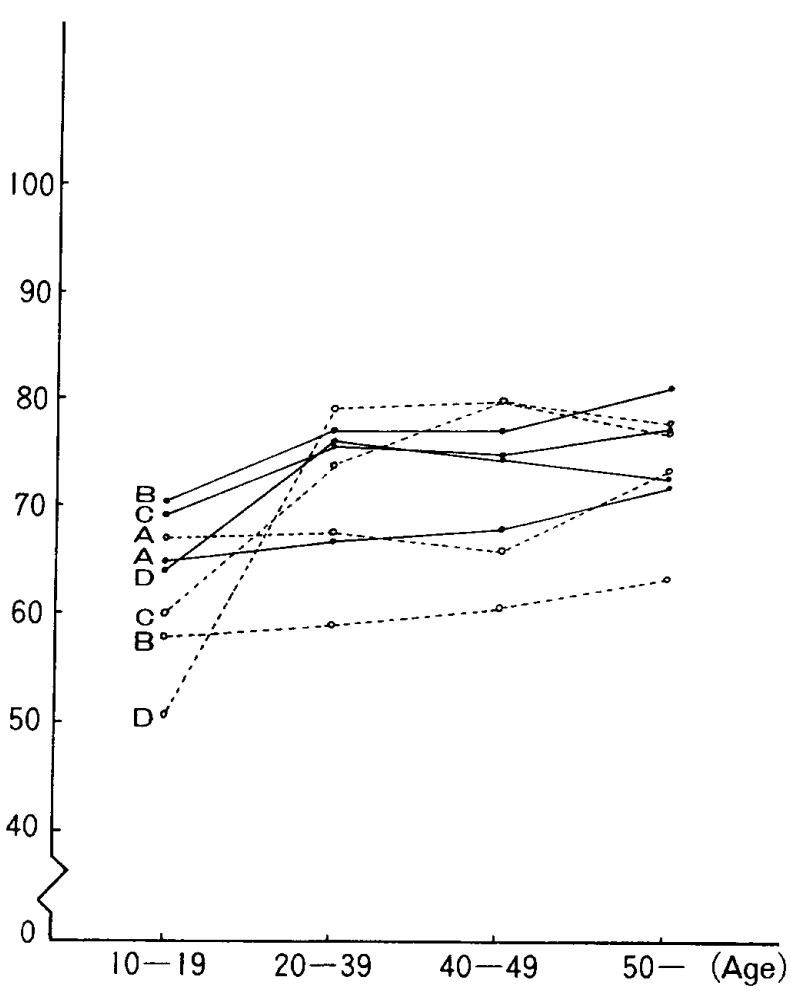

Fig. 10 Dentin index on lower second premolar 
Table 12 Diameter of dentin on lower first premolar

(mm)

\begin{tabular}{|c|c|c|c|c|c|c|c|c|c|c|}
\hline \multicolumn{3}{|c|}{ Age } & \multicolumn{2}{|c|}{$10-19$} & \multicolumn{2}{|c|}{$20-39$} & 40 & 49 & \multicolumn{2}{|c|}{$50-$} \\
\hline \multicolumn{3}{|c|}{ Section } & $M-D$ & $B-L$ & $M-D$ & $B-L$ & $M-D$ & $B-L$ & $M-D$ & $B-L$ \\
\hline \multirow{3}{*}{0} & \multirow{3}{*}{ A } & $\mathrm{N}$ & 15 & 15 & 12 & 12 & 14 & 14 & 22 & 22 \\
\hline & & $\bar{X}$ & 5.19 & 5.05 & 4.93 & 5.03 & 4.89 & 5.06 & 5.03 & 5.52 \\
\hline & & S.D. & 0.40 & 0.67 & 0.34 & 0.71 & 0.42 & 1.03 & 0.40 & 0.54 \\
\hline \multirow{9}{*}{1} & \multirow{3}{*}{ B } & $\mathrm{N}$ & 19 & 19 & 14 & 14 & 31 & 31 & 30 & 30 \\
\hline & & $\bar{X}$ & 3.61 & 4.56 & 3.76 & 4.37 & 3.84 & 4.39 & 3.93 & 4.52 \\
\hline & & S.D. & 0.31 & 0.35 & 0.35 & 0.44 & 0.27 & 0.38 & 0.33 & 0.35 \\
\hline & \multirow{3}{*}{$\mathrm{C}$} & $\mathrm{N}$ & 19 & 19 & 14 & 14 & 31 & 31 & 30 & 30 \\
\hline & & $\bar{X}$ & 2.74 & 3.85 & 2.83 & $4 \cdot 55$ & 2.96 & 4.88 & 2.96 & 5.03 \\
\hline & & S.D. & 0.28 & 0.64 & 0.25 & 0.54 & 0.40 & 0.58 & 0.29 & 0.48 \\
\hline & \multirow{3}{*}{ D } & $\mathrm{N}$ & 19 & 19 & 14 & 14 & 31 & 31 & 30 & 30 \\
\hline & & $\bar{X}$ & 1.97 & 2.64 & 2.03 & 3.44 & 2.23 & 3.81 & 2.33 & 4.05 \\
\hline & & S.D. & 0.28 & 0.89 & 0.26 & 0.35 & 0.38 & 0.89 & 0.38 & 0.65 \\
\hline
\end{tabular}

Table 13

Dentin index on lower first premolar

\begin{tabular}{|c|c|c|c|c|c|c|c|c|c|c|}
\hline \multicolumn{3}{|c|}{ Age } & \multicolumn{2}{|c|}{$10-19$} & \multicolumn{2}{|c|}{$20-39$} & \multicolumn{2}{|c|}{$40-49$} & \multicolumn{2}{|c|}{$50-$} \\
\hline \multicolumn{3}{|c|}{ Section } & $\mathrm{M}-\mathrm{D}$ & $B-L$ & $M-D$ & $B-L$ & $M-D$ & $\mathrm{~B}-\mathrm{L}$ & $M-D$ & $B-L$ \\
\hline \multirow{3}{*}{0} & \multirow{3}{*}{ A } & $\mathrm{N}$ & 15 & 15 & 12 & 12 & 14 & 14 & 22 & 22 \\
\hline & & $\bar{X}$ & 70.81 & 66.83 & 68.55 & 65.91 & 72.48 & 66.89 & 72.58 & 72.30 \\
\hline & & S.D. & 2.93 & 4.09 & 3.15 & 7.13 & 5.69 & 10.07 & $4 \cdot 21$ & 5.03 \\
\hline \multirow{9}{*}{1} & \multirow{3}{*}{ B } & $\mathrm{N}$ & 19 & 19 & 14 & 14 & 31 & 31 & 30 & 30 \\
\hline & & $\bar{X}$ & 71.93 & 62.82 & 78.08 & 62.43 & 81.70 & 63.84 & 83.03 & 64.72 \\
\hline & & S.D. & 6.14 & 5.05 & 6.11 & 3.60 & $4 \cdot 15$ & 4.77 & 2.83 & 4.89 \\
\hline & \multirow{3}{*}{$\mathrm{C}$} & $\mathrm{N}$ & 19 & 19 & 14 & 14 & 31 & 31 & 30 & 30 \\
\hline & & $\bar{X}$ & $68 \cdot 32$ & 57.63 & 76.85 & 75.65 & 77.68 & 79.43 & $78 \cdot 14$ & 79.37 \\
\hline & & S.D. & 4.76 & 7.15 & 4.05 & 6.41 & 4.05 & 7.62 & 3.70 & $4 \cdot 33$ \\
\hline & \multirow{3}{*}{$\mathrm{D}$} & $\mathrm{N}$ & 19 & 19 & 14 & 14 & 31 & 31 & 30 & 30 \\
\hline & & $\bar{X}$ & 62.34 & 49.05 & 75.31 & 79.66 & 75.18 & 78.23 & 74.00 & 80.42 \\
\hline & & S.D. & 8.62 & 16.22 & 3.27 & 2.74 & 5.38 & 6.66 & 6.42 & 6.62 \\
\hline
\end{tabular}


Table 14

Diameter of dentin on lower second premolar

$(\mathrm{mm})$

\begin{tabular}{|c|c|c|c|c|c|c|c|c|c|c|}
\hline \multirow{2}{*}{\multicolumn{3}{|c|}{$\begin{array}{c}\text { Age } \\
\text { Section }\end{array}$}} & \multirow{2}{*}{\multicolumn{2}{|c|}{$\begin{aligned} 10-19 \\
M-D \quad B-L\end{aligned}$}} & \multirow{2}{*}{\multicolumn{2}{|c|}{$\begin{array}{rr}20-39 \\
M-D \quad B-L\end{array}$}} & \multirow{2}{*}{\multicolumn{2}{|c|}{$\begin{array}{c}40-49 \\
M-D \quad B-L\end{array}$}} & \multicolumn{2}{|c|}{$50-$} \\
\hline & & & & & & & & & $M-D$ & $B-L$ \\
\hline \multirow{3}{*}{0} & \multirow{3}{*}{ A } & $\mathrm{N}$ & 4 & 4 & 9 & 9 & 25 & 25 & 25 & 25 \\
\hline & & $\bar{X}$ & 4.85 & 5.42 & 4.80 & 5.31 & 4.89 & 5.34 & 5.13 & 6.02 \\
\hline & & S.D. & 0.11 & 0.49 & 0.33 & 0.47 & 0.37 & 1.13 & 0.35 & 0.80 \\
\hline \multirow{9}{*}{1} & \multirow{3}{*}{ B } & $\mathbf{N}$ & 4 & 4 & 10 & 10 & 26 & 26 & 27 & 27 \\
\hline & & $\bar{X}$ & 3.51 & 4.21 & 3.75 & 4.25 & 3.89 & 4.37 & 4.03 & 4.69 \\
\hline & & S.D. & 0.09 & 0.23 & 0.29 & 0.34 & 0.36 & 0.35 & 0.35 & 0.58 \\
\hline & \multirow{3}{*}{$\mathrm{C}$} & $\mathrm{N}$ & 4 & 4 & 10 & 10 & 26 & 26 & 27 & 27 \\
\hline & & $\mathrm{X}$ & 2.69 & 4.03 & 2.92 & 4.54 & 2.94 & 4.81 & 3.03 & 4.85 \\
\hline & & S.D. & 0.14 & 0.74 & 0.38 & 0.61 & 0.28 & 0.51 & 0.34 & 0.64 \\
\hline & \multirow{3}{*}{$\mathrm{D}$} & $\mathrm{N}$ & 4 & 4 & 10 & 10 & 26 & 26 & 27 & 27 \\
\hline & & $\bar{X}$ & 1.85 & 2.45 & 2.37 & 3.73 & 2.34 & 3.64 & 2.37 & 3.77 \\
\hline & & $S \cdot D$ & 0.03 & 0.67 & 0.33 & 0.45 & 0.35 & 0.57 & 0.37 & 0.73 \\
\hline
\end{tabular}

Table 15 Dentin index on lower second premolar

\begin{tabular}{|c|c|c|c|c|c|c|c|c|c|c|}
\hline \multirow{2}{*}{\multicolumn{3}{|c|}{$\begin{array}{c}\text { Age } \\
\text { Section }\end{array}$}} & \multirow{2}{*}{\multicolumn{2}{|c|}{$\begin{array}{c}10-19 \\
M-D \quad B-L\end{array}$}} & \multirow{2}{*}{\multicolumn{2}{|c|}{$\begin{array}{rr}20-39 \\
M-D & B-L\end{array}$}} & \multicolumn{2}{|c|}{$40-49$} & \multicolumn{2}{|c|}{$50-$} \\
\hline & & & & & & & $M-D$ & $B-L$ & $M-D$ & $B-L$ \\
\hline \multirow{3}{*}{0} & \multirow{3}{*}{ A } & $\mathrm{N}$ & 4 & 4 & 9 & 9 & 25 & 25 & 25 & 25 \\
\hline & & $\bar{X}$ & 65.37 & 67.66 & 67.53 & 68.40 & 68.68 & 66.75 & 72.55 & 74.12 \\
\hline & & $S \cdot D$ & 2.71 & 3.08 & 3.57 & 6.12 & 4.66 & 12.91 & 4.33 & 6.33 \\
\hline \multirow{9}{*}{1} & \multirow{3}{*}{ B } & $\mathrm{N}$ & 4 & 4 & 10 & 10 & 26 & 26 & 27 & 27 \\
\hline & & $\bar{X}$ & 70.71 & $58 \cdot 44$ & 77.82 & 59.66 & 77.97 & 61.56 & 81.94 & 64.26 \\
\hline & & $\mathrm{S} \cdot \mathrm{D}$ & 2.65 & 5.69 & 3.42 & 3.83 & 8.39 & 6.28 & 5.69 & 8.70 \\
\hline & \multirow{3}{*}{$\mathrm{C}$} & $\mathbf{N}$ & 4 & 4 & 10 & 10 & 26 & 26 & 27 & 27 \\
\hline & & $\bar{X}$ & 69.75 & 60.52 & 76.55 & 74.74 & 75.61 & 80.58 & 77.85 & 77.83 \\
\hline & & $\mathrm{S} \cdot \mathrm{D}$ & 4.73 & 10.80 & 3.23 & 8.23 & 2.92 & 4.61 & 3.31 & 8.37 \\
\hline & \multirow{3}{*}{$\mathrm{D}$} & $\mathrm{N}$ & 4 & 4 & 10 & 10 & 26 & 26 & 27 & 27 \\
\hline & & $\overline{\mathrm{X}}$ & 64.41 & 51.05 & 76.77 & 79.99 & $75 \cdot 22$ & 80.56 & 73.54 & 78.21 \\
\hline & & $S \cdot D$ & 2.67 & 13.85 & $4 \cdot 34$ & 5.64 & 5.92 & 4.64 & 5.65 & 4.96 \\
\hline
\end{tabular}


$(\mathrm{mm})$

\begin{tabular}{|c|c|c|c|c|c|c|c|c|c|c|c|}
\hline & & Age & & 10 & & 20 & -39 & $40-$ & -49 & $50-$ & \\
\hline & & ctic & & $M-D$ & $B-L$ & $M-D$ & $B-I$ & $M-D$ & $\bar{B}-\mathrm{L}$ & $M-D$ & $B-L$ \\
\hline & & & $\mathrm{N}$ & 19 & 19 & 5 & 5 & 10 & 10 & 12 & 12 \\
\hline & & C & $\bar{X}$ & 0.03 & 0.02 & 0.09 & 0.09 & 0.11 & 0.13 & 0.17 & 0.23 \\
\hline & & & $\mathrm{S} \cdot \mathrm{D}$ & 0.04 & 0.04 & 0.06 & 0.03 & 0.08 & 0.09 & 0.17 & 0.36 \\
\hline & & & $\mathrm{N}$ & 17 & 17 & 10 & 10 & 15 & 15 & 19 & 19 \\
\hline & & D & $\bar{X}$ & 0.11 & 0.11 & 0.20 & 0.28 & 0.22 & 0.33 & 0.37 & 0.39 \\
\hline & & & $\mathrm{S} \cdot \mathrm{D}$ & 0.14 & 0.12 & 0.09 & 0.19 & 0.08 & 0.18 & 0.35 & 0.41 \\
\hline 1 & & & $\mathrm{~N}$ & 2 & 2 & 11 & 11 & 17 & 17 & 13 & 13 \\
\hline & & C & $\bar{X}$ & 0.00 & 0.00 & 0.07 & 0.10 & 0.08 & 0.10 & 0.13 & 0.17 \\
\hline & $P_{2}$ & & $\mathrm{~S} \cdot \mathrm{D}$ & & & 0.06 & 0.09 & 0.04 & 0.06 & 0.07 & 0.11 \\
\hline & & & $\mathrm{N}$ & 2 & 2 & 14 & 14 & 21 & 21 & 22 & 22 \\
\hline & & $\mathrm{D}$ & $\overline{\mathrm{X}}$ & 0.15 & 0.12 & 0.26 & 0.28 & 0.30 & 0.33 & 0.37 & 0.43 \\
\hline & & & $\mathrm{S} \cdot \mathrm{D}$ & 0.13 & 0.03 & 0.20 & 0.20 & 0.29 & 0.26 & 0.35 & 0.34 \\
\hline & & & $\mathrm{N}$ & 1 & 1 & 11 & 11 & 20 & 20 & 17 & 17 \\
\hline & & $\mathrm{C}$ & $\bar{X}$ & 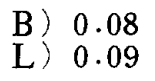 & 0.08 & $\begin{array}{ll}\text { B) } & 0.10 \\
\text { L) } & 0.10\end{array}$ & 0.10 & $\begin{array}{ll}\text { B) } & 0.13 \\
\text { L) } & 0.12\end{array}$ & 0.12 & $\begin{array}{ll}\text { B) } & 0.12 \\
\text { L) } & 0.12\end{array}$ & 0.14 \\
\hline & D & & $\mathrm{S} \cdot \mathrm{D}$ & & & $\begin{array}{l}\text { B) } 0.04 \\
\text { L) } 0.08\end{array}$ & 0.05 & $\begin{array}{ll}\text { B) } & 0.06 \\
\text { L) } & 0.06\end{array}$ & 0.06 & 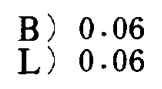 & 0.09 \\
\hline & & & $\mathrm{N}$ & 3 & 3 & 5 & 5 & 11 & 11 & 8 & 8 \\
\hline & & $\mathrm{D}$ & $\bar{X}$ & $\begin{array}{ll}\text { B) } & 0.13 \\
\text { L) } & 0.16\end{array}$ & 0.16 & $\begin{array}{ll}\text { B) } & 0.20 \\
\text { L) } & 0.17\end{array}$ & 0.21 & $\begin{array}{ll}\text { B) } & 0.29 \\
\text { L) } & 0.32\end{array}$ & 0.31 & 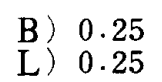 & 0.30 \\
\hline ? & & & $S \cdot D$ & $\begin{array}{ll}\text { B) } & 0.03 \\
\text { L) } & 0.03\end{array}$ & 0.03 & $\begin{array}{l}\text { B) } \\
\text { L) } \\
0.09\end{array}$ & 0.14 & $\begin{array}{ll}\text { B) } & 0.15 \\
\text { L) } & 0.16\end{array}$ & 0.13 & $\begin{array}{ll}\text { B) } & 0.04 \\
\text { L) } & 0.09\end{array}$ & 0.07 \\
\hline & & & $\mathrm{N}$ & & & 4 & 4 & 9 & 9 & 13 & 13 \\
\hline & & C & $\bar{X}$ & & & $\begin{array}{l}\text { B) } 0.15 \\
\text { L) } \\
0.17\end{array}$ & 0.17 & $\begin{array}{ll}\text { B) } & 0.10 \\
\text { L) } & 0.12\end{array}$ & 0.11 & $\begin{array}{ll}\text { B) } & 0.13 \\
\text { L) } & 0.13\end{array}$ & 0.15 \\
\hline & $\mathrm{P}$ & & $\mathrm{S} \cdot \mathrm{D}$ & & & $\begin{array}{l}\text { B) } \\
\text { L) } \\
0.08\end{array}$ & 0.13 & $\begin{array}{l}\text { B) } \\
\text { L) } \\
0.09\end{array}$ & 0.11 & 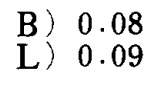 & 0.12 \\
\hline & & & $\mathrm{N}$ & & & 1 & 1 & 5 & 5 & 4 & 4 \\
\hline & & $\mathrm{D}$ & $\bar{X}$ & & & $\begin{array}{ll}\text { B) } & 0.15 \\
\text { L) } & 0.15\end{array}$ & 0.23 & $\begin{array}{ll}\text { B) } & 0.18 \\
\text { L) } & 0.24\end{array}$ & 0.25 & $\begin{array}{ll}\text { B) } & 0.29 \\
\text { L) } & 0.36\end{array}$ & 0.30 \\
\hline & & & $\mathrm{S} \cdot \mathrm{D}$ & & & & & $\begin{array}{l}\text { B) } 0.04 \\
\text { L) } 0.14\end{array}$ & 0.07 & $\begin{array}{ll}\text { B) } & 0.12 \\
\text { L) } & 0.22\end{array}$ & 0.12 \\
\hline & & & $\mathrm{N}$ & & & 1 & 1 & 4 & 4 & 2 & 2 \\
\hline $2 \mathrm{R}$ & $\underline{P_{1}}$ & $\mathrm{D}$ & $\bar{X}$ & & & $\begin{array}{l}\text { B) } 0.34 \\
\text { L) } \\
0.56\end{array}$ & $\begin{array}{ll}\text { B) } & 0.35 \\
\text { L) } & 0.44\end{array}$ & $\begin{array}{l}\text { B) } 0.18 \\
\text { L) } 0.23\end{array}$ & $\begin{array}{ll}\text { B) } & 0.19 \\
\text { L) } & 0.33\end{array}$ & $\begin{array}{l}\text { B) } 0.20 \\
\text { L) } \\
0.22\end{array}$ & $\begin{array}{ll}\text { B) } & 0.20 \\
\text { L) } & 0.30\end{array}$ \\
\hline & & & $S \cdot D$. & & & & & $\begin{array}{ll}\text { B) } & 0.06 \\
\text { L) } & 0.05\end{array}$ & $\begin{array}{l}\text { B) } \\
\text { L) } \\
0.02 \\
\text { L }\end{array}$ & $\begin{array}{ll}\text { B) } & 0.00 \\
\text { L) } & 0.02\end{array}$ & $\begin{array}{ll}\text { B) } & 0.00 \\
\text { L) } & 0.18\end{array}$ \\
\hline
\end{tabular}

根管䨑のC・D部においては，増秢的に著しい増加傾向 が認められ，特に10才代から20・30才代への変化では， C 部の近遠心径で $5 \%$ 以下，煩舌徍で $1 \%$ 以下，またD 部の煩舌径では，1\%以下の水準で有意差がみられた。 2 根管蒾でも増柃に伴い多少の増加順向がみられるが，
有意差は認められなかった。 2 根蒾では，大きな変化は 㢹められなかった。

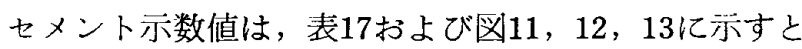
おらである，1根管雨は，増龄に従い著しい増加傾问を 示しており，C部の近遠心径, 煩舌径と $\mathrm{D}$ 部の煩舌径で 
Table 17

Cement index on upper premolar

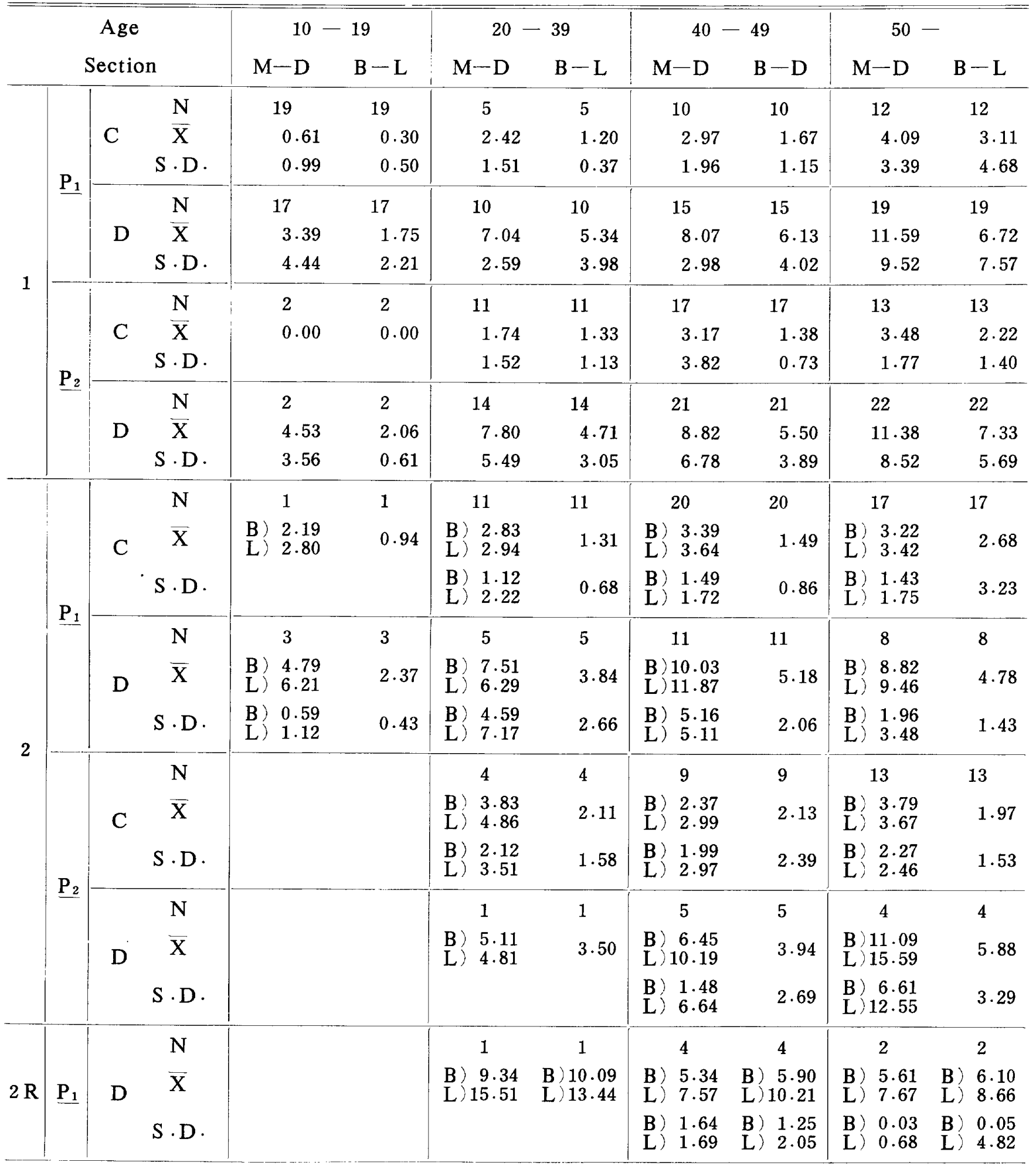

は $1 \%$ 以下で，D部の近遠心径では $5 \%$ 以下で，いずれ も10才代から20・30才代へかけて有意差が認められた。

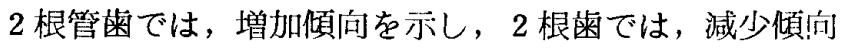
をみせているが，双方とも有意の差は羿められなかっ た.

\section{2. 上影第 2 小曰茵}

表16のでとく，上頡第 1 小曰菌と同様に，増略に伴う 著明な増加傾向がみられ，1根管柬では，C部の煩舌径 の40才代から50才以上にかけて，5\%以下の水準で有意

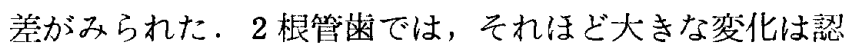




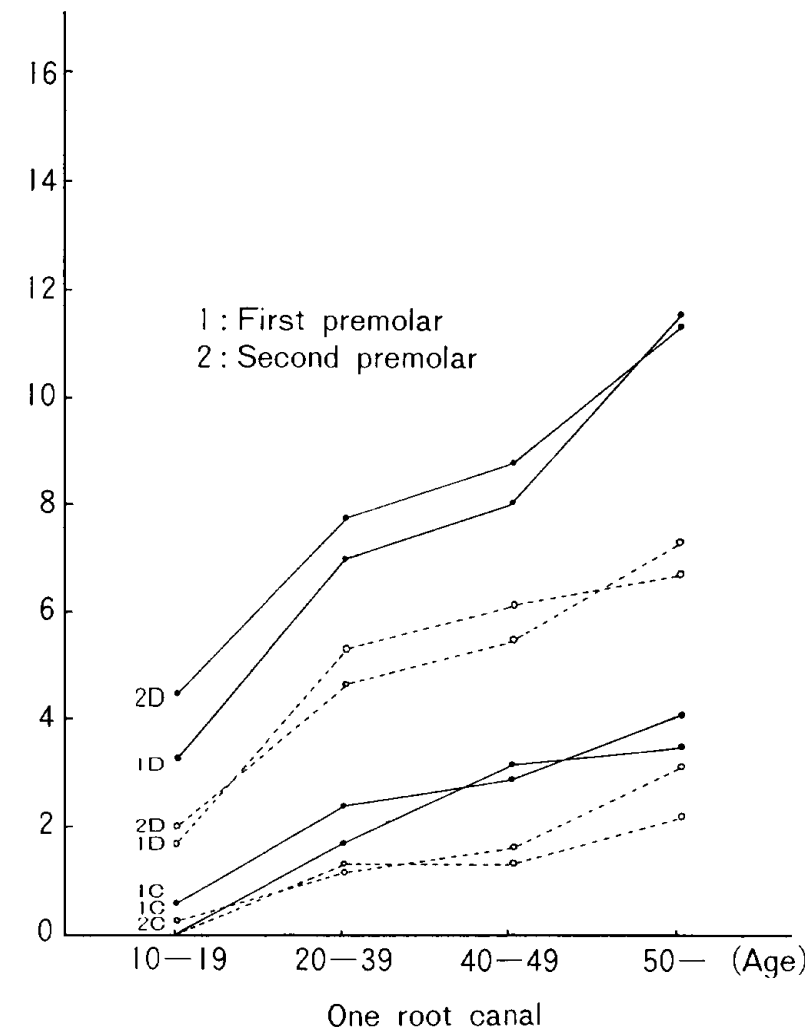

Fig. 11 Cement index on upper premolar

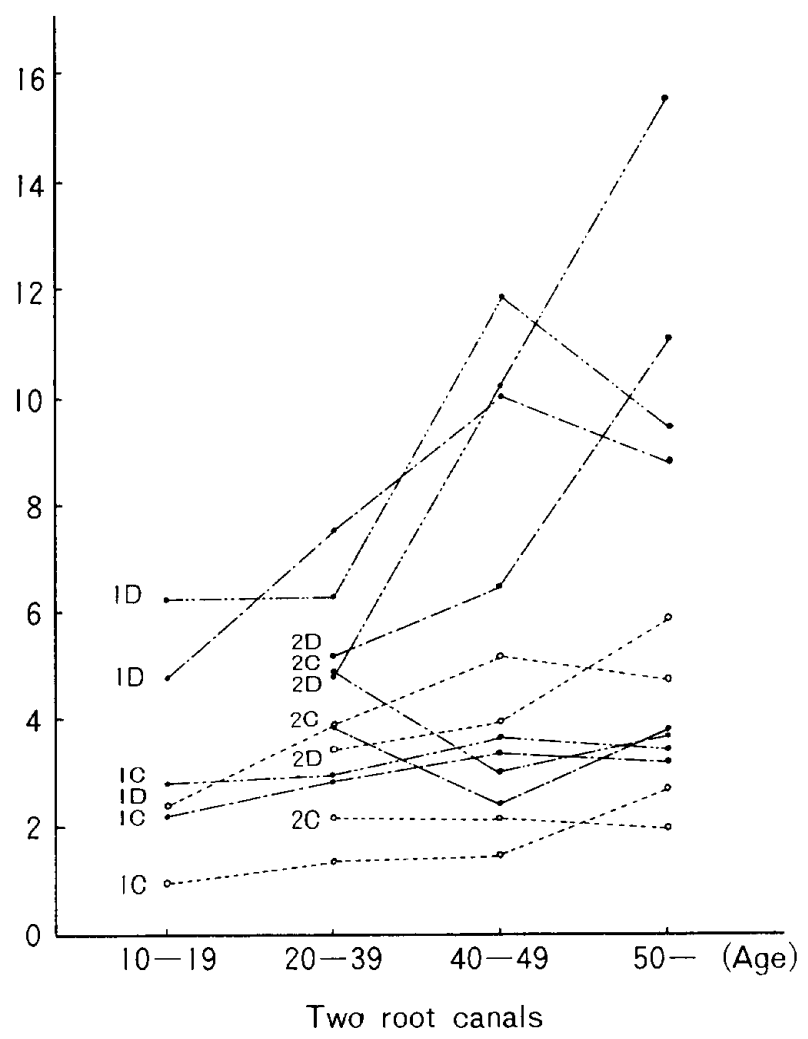

Fig. 12 Cement index on upper premolar

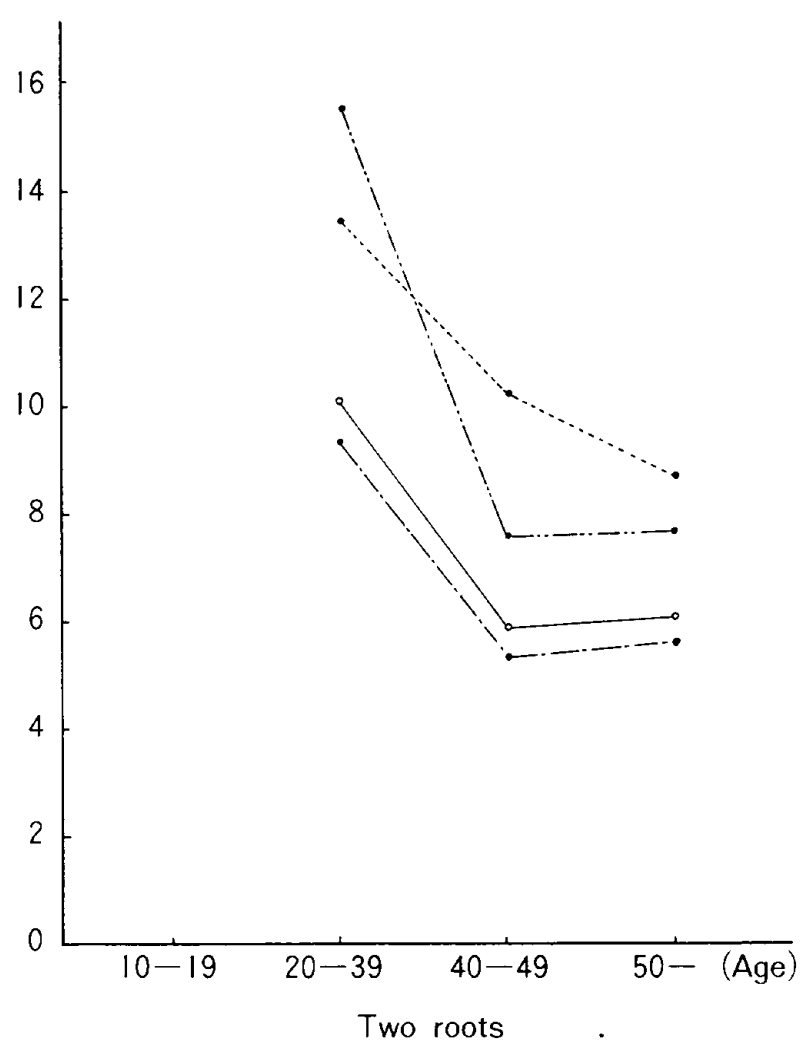

Fig. 13 Cement index on upper premolar

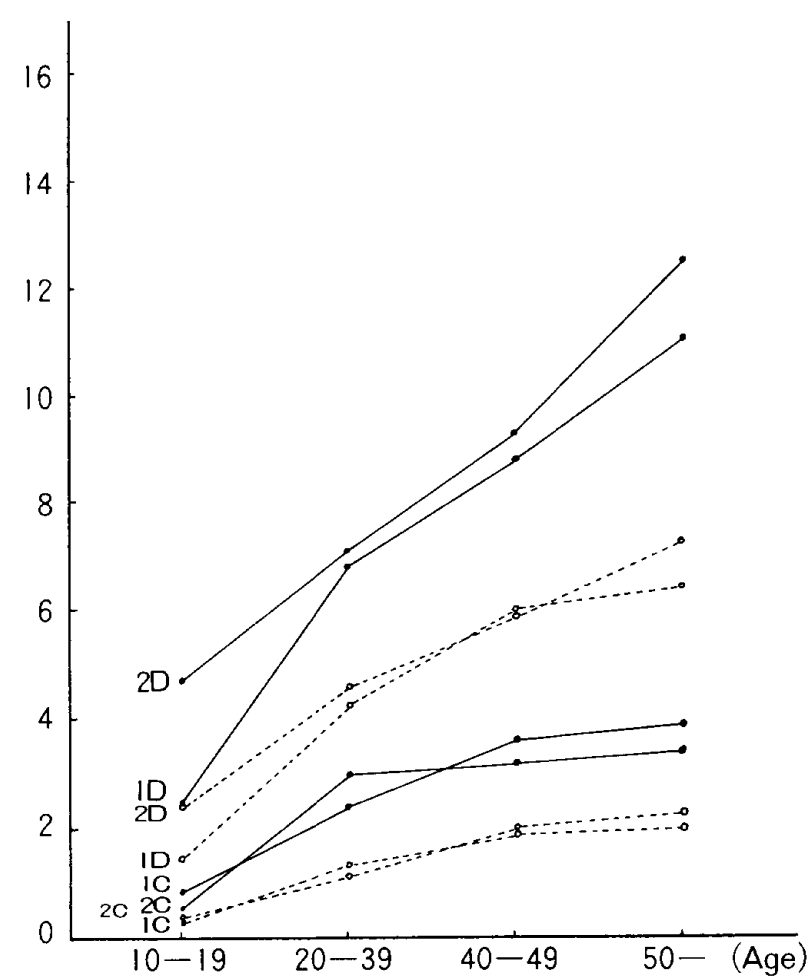

Fig. 14 Cement index on lower premolar 
められなかった。

示数值は，表17および図11と12に示すように，1 根管 歯では, $\mathrm{C} ・ \mathrm{D}$ 部とも增龄的に増加を示し, 特にC部の 煩舌径では40才代加ら50才以上へかけて，5\%以下の水 準で有意差がみられた，2根管歯では，C部での近遠心 径に20・30才代から40才代にかけて娍少傾问がみられ，

D部では増秢的に増加傾问がみられたが，全般的には大 きな変化は諗められなかった。

3. 下頇第 1 小代㐘
下頼小曰㐘の計測值は，表18に示すとおりである。C ・D部ともに著しい増加を示している，有意差が誹めら れるのは，C部における10才代から20・30才代にかけて の近遠心径抢よび煩舌径，ならびに20・30才代から40才 代へかけての近遠心径および煩舌径であった。また，D 部では10才代と $20 \cdot 30$ 才代との間の近遠心径, 煩舌径, 20 - 30才代と 40 手代との間の煩舌径，40才代と50才以上 との䦩の近遠心径に，それぞれ有意の差がみられた。 セメント示数值は, 表19および図14のごとくである.

Table 18

Diameter of cement on lower premolar

$(\mathrm{mm})$

\begin{tabular}{|c|c|c|c|c|c|c|c|c|c|c|c|}
\hline & & Age & & & 19 & 20 & 39 & & 49 & 50 & \\
\hline & & $\mathrm{cti}$ & & $M-D$ & $B-L$ & $M-D$ & $B-L$ & $M-D$ & $B-L$ & $M-D$ & $B-L$ \\
\hline & & & $\mathrm{N}$ & 19 & 19 & 14 & 14 & 31 & 31 & 30 & 30 \\
\hline & & $\mathrm{C}$ & $\bar{X}$ & 0.04 & 0.02 & 0.09 & 0.07 & 0.14 & 0.12 & 0.15 & 0.14 \\
\hline & & & S.D. & 0.05 & 0.04 & 0.06 & 0.04 & 0.07 & 0.06 & 0.07 & 0.08 \\
\hline & & & $\mathrm{N}$ & 19 & 19 & 14 & 14 & 31 & 31 & 30 & 30 \\
\hline & & $\mathrm{D}$ & $\mathrm{X}$ & 0.08 & 0.08 & 0.19 & 0.18 & 0.26 & 0.28 & 0.36 & 0.28 \\
\hline & & & $S \cdot D$ & 0.04 & 0.04 & 0.07 & 0.07 & 0.15 & 0.14 & 0.22 & 0.16 \\
\hline 1 & & & $\mathrm{~N}$ & 4 & 4 & 10 & 10 & 26 & 26 & 27 & 27 \\
\hline & & $\mathrm{C}$ & $\bar{X}$ & 0.02 & 0.03 & 0.12 & 0.08 & 0.13 & 0.12 & 0.14 & 0.13 \\
\hline & & & S.D. & 0.04 & 0.05 & 0.08 & 0.04 & 0.06 & 0.06 & 0.09 & 0.08 \\
\hline & & & $\mathrm{N}$ & 4 & 4 & 10 & 10 & 26 & 26 & 27 & 27 \\
\hline & & D & $\bar{X}$ & 0.14 & 0.12 & 0.22 & 0.23 & 0.30 & 0.27 & 0.41 & 0.35 \\
\hline & & & S.D. & 0.05 & 0.09 & 0.11 & 0.13 & 0.19 & 0.12 & 0.23 & 0.18 \\
\hline
\end{tabular}

Table 19 Cement index on lower premolar

\begin{tabular}{|c|c|c|c|c|c|c|c|c|c|c|c|}
\hline & & Age & & & 19 & 20 & 39 & 40 & 49 & & \\
\hline & & $\operatorname{cti}$ & & $M-D$ & $B-L$ & $\mathrm{M}-\mathrm{D}$ & $B-L$ & $M-D$ & $B-L$ & $M-D$ & $B-L$ \\
\hline & & & $\mathrm{N}$ & 19 & 19 & 14 & 14 & 31 & 31 & 30 & 30 \\
\hline & & $\mathrm{C}$ & $\bar{X}$ & 0.88 & 0.37 & 2.46 & 1.17 & 3.69 & 2.05 & 3.96 & $2 \cdot 32$ \\
\hline & & & $S \cdot D$. & 1.26 & 0.55 & 1.61 & 0.76 & 1.78 & $1 \cdot 14$ & 1.96 & 1.29 \\
\hline & & & $\mathrm{N}$ & 19 & 19 & 14 & 14 & 31 & 31 & 30 & 30 \\
\hline & & $\mathrm{D}$ & $X$ & 2.53 & 1.50 & 6.92 & 4.35 & 8.94 & 6.08 & 11.19 & 6.51 \\
\hline & & & S.D. & 1.35 & 0.76 & 2.52 & 1.86 & 4.74 & 3.73 & 6.38 & 4.76 \\
\hline 1 & & & $\mathrm{~N}$ & 4 & 4 & 10 & 10 & 26 & 26 & 27 & 27 \\
\hline & & $\mathrm{C}$ & $\bar{X}$ & 0.54 & 0.39 & 3.05 & 1.33 & 3.27 & 1.95 & 3.50 & 2.05 \\
\hline & & & S.D. & 1.08 & 0.77 & 1.89 & 0.85 & 1.44 & 1.00 & 2.01 & 1.42 \\
\hline & & & $\mathrm{N}$ & 4 & 4 & 10 & 10 & 26 & 26 & 27 & 27 \\
\hline & & $\mathrm{D}$ & $\bar{X}$ & 4.83 & 2.51 & 7.20 & 4.69 & 9.43 & 6.03 & 12.61 & 7.35 \\
\hline & & & S.D. & 2.01 & 1.79 & 3.32 & 2.33 & 4.97 & 2.95 & 6.33 & 4.19 \\
\hline
\end{tabular}


計測値同様，增秢的に著明な增加傾向を示しているが， 10 才代から $20 \cdot 30$ 才代へかけてのC・D部の近遠心径， 煩舌径ともに，また20・30才代から40才代にかけては， C部の近遠心径，煩舌径で有意差がみられた．

\section{4. 下䫑第 2 小罒歯}

この㐘の計测值においても，増龄に伴い增加傾何が認 められるが，下頻第 1 小曰歯ほど著しい変化はみられな かった，有意差はC 部の近遠心径の10才代から 20 ・ 30才 代にかけてみられた。

亦数值も増秢的増加傾向走示し, $C$ 部の近遠心徍の 10 才代と $20 \cdot 30$ 才代との間およびD部での近遠心径の40 才代と50才以上の間において有意差が認められた。

\section{E . 米䯙腔の計測值および示数値}

1. 上顎第 1 小巨篓

この蒾の計測值の成績は，表20のと扔りである．各部 とも増齢に従い娍少傾向がみられるが， 1 根管茵では10 才代から $20 \cdot 30$ 才代への変化が著明で，B・C・D各部 の近遠心径，煩舌径ともに，1\%以下の危険率で有意差 が認められた。しかし，20・30才代以降の変化はわずか であった。 2 根管雨と 2 根菌においては，增略的にやや 娍少傾向がみられたが，有意差は誌められなかった。

髄腔示数は，表 21 および図 $15 ， 16 ， 17$ 亿示すごとく で，1根管柬では， B・C・D各部とも增齢に伴い減少 倾何を示し，計測值と同様，10才代から20・30才代へか

Table 20 Diameter of pulp cavity on upper first premolar

(mm)

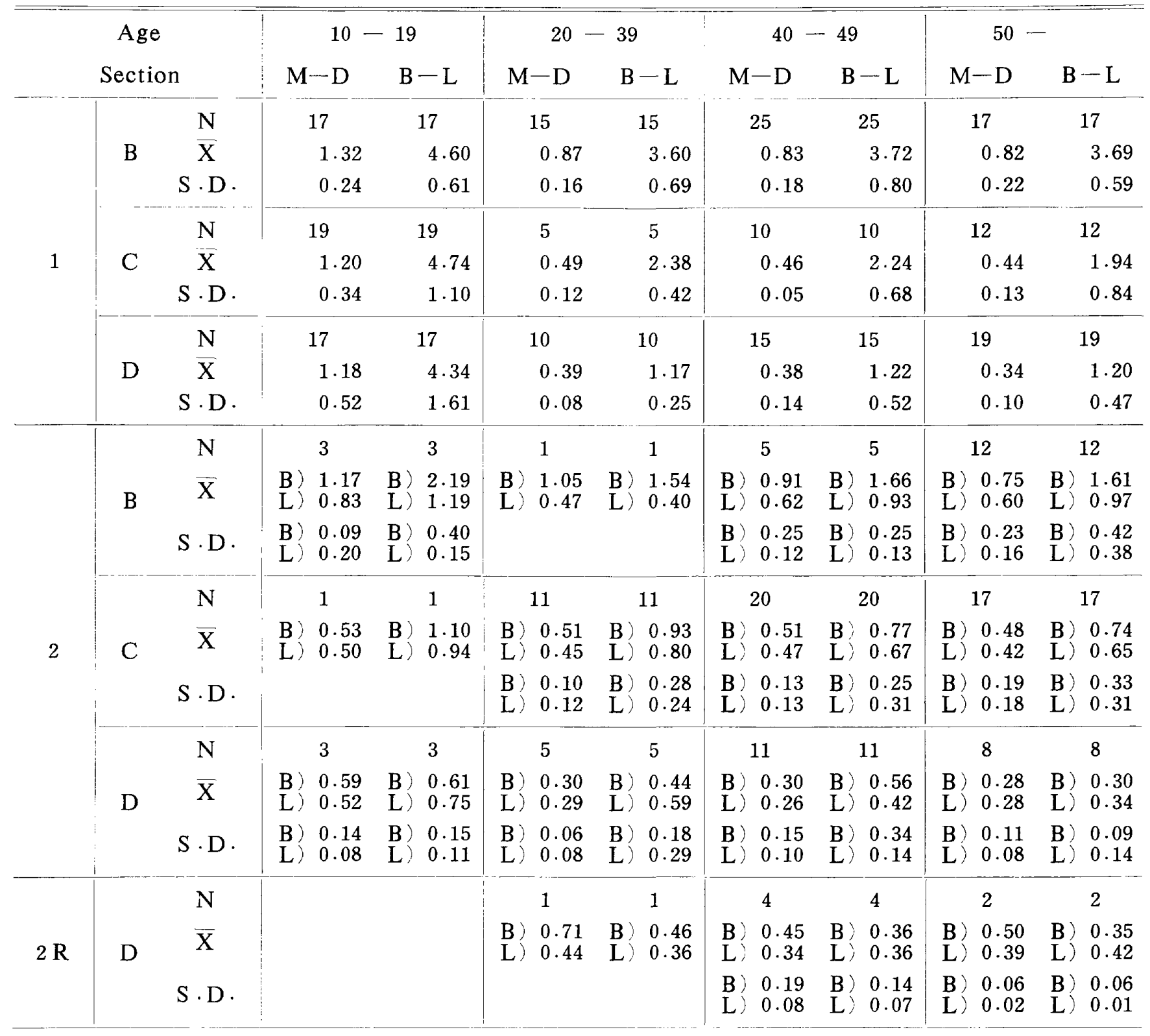


Table $21 \quad$ Pulp cavity index on upper first premolar

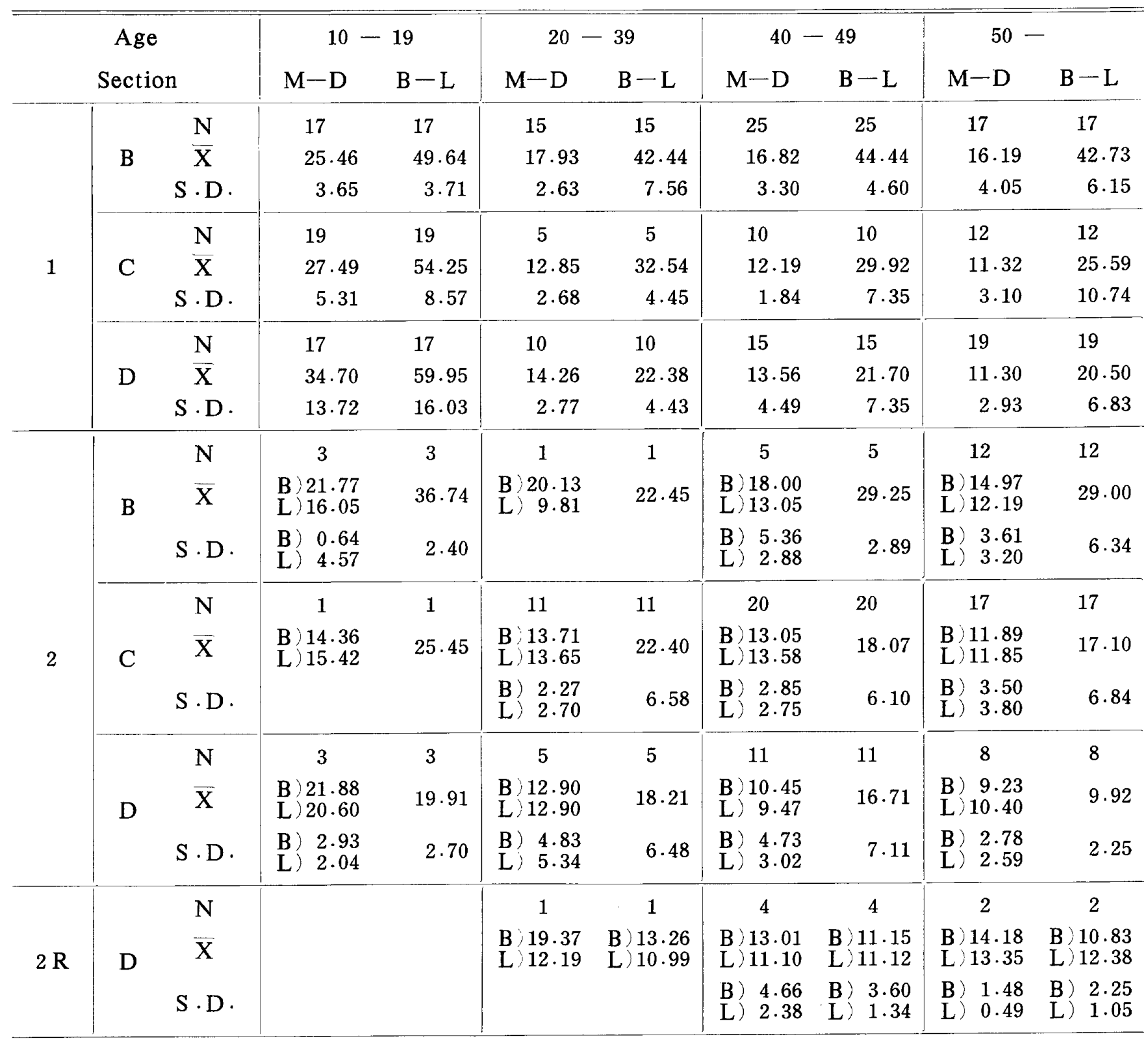

けてのすべてにおいて有意の差が諗められた。 2 根管歯 では，増齢的に減少傾们がみられたが，D部の40才代と 50才以上との年柃群間以外では，有意差は㤠められなか った。 2 根歯では，増秢的な変化はほとんぞ䜑められな かった。

\section{2 . 上顎第 2 小曰崡}

計測結果は，表22のとおりである．1根管棶において は, 増粭に伴い減少傾何を示し，特に10才代から $20 \cdot 30$ 才代への変化は著しく, $\mathrm{B} \cdot \mathrm{C}$ 部での近遠心径と $\mathrm{D}$ 部で の近遠心径および煩舌径では，1\%以下の水準で有意の 差が認められた。２根管菊においても，増榆的に減少傾 问が琶められ，B・C部の煩側根管側の煩舌径に，40才
代から50才以上にかけての変化で有意の差がみられた。

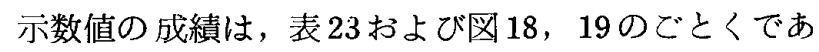
る. 10 才代から 20 -30才代への増粭的減少が顕著で，特 に B・C部の近遠心径とD部の近遠心径および頓舌径で は，1\%以下の水準で有意の差が琹められた。しかし， 20 ・30才代以降の増秢的変化は著明なものはみられなか った． 2 根管歯では，堌秢に伴う減少傾庁がみられ，40 才代から50才以上にかけての変化において，B部の煩側 根管側の近遠心径ならびに，C部の煩舌径において有意 差がみられた。

3. 下顎第 1 小曰米

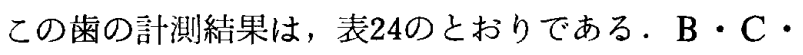



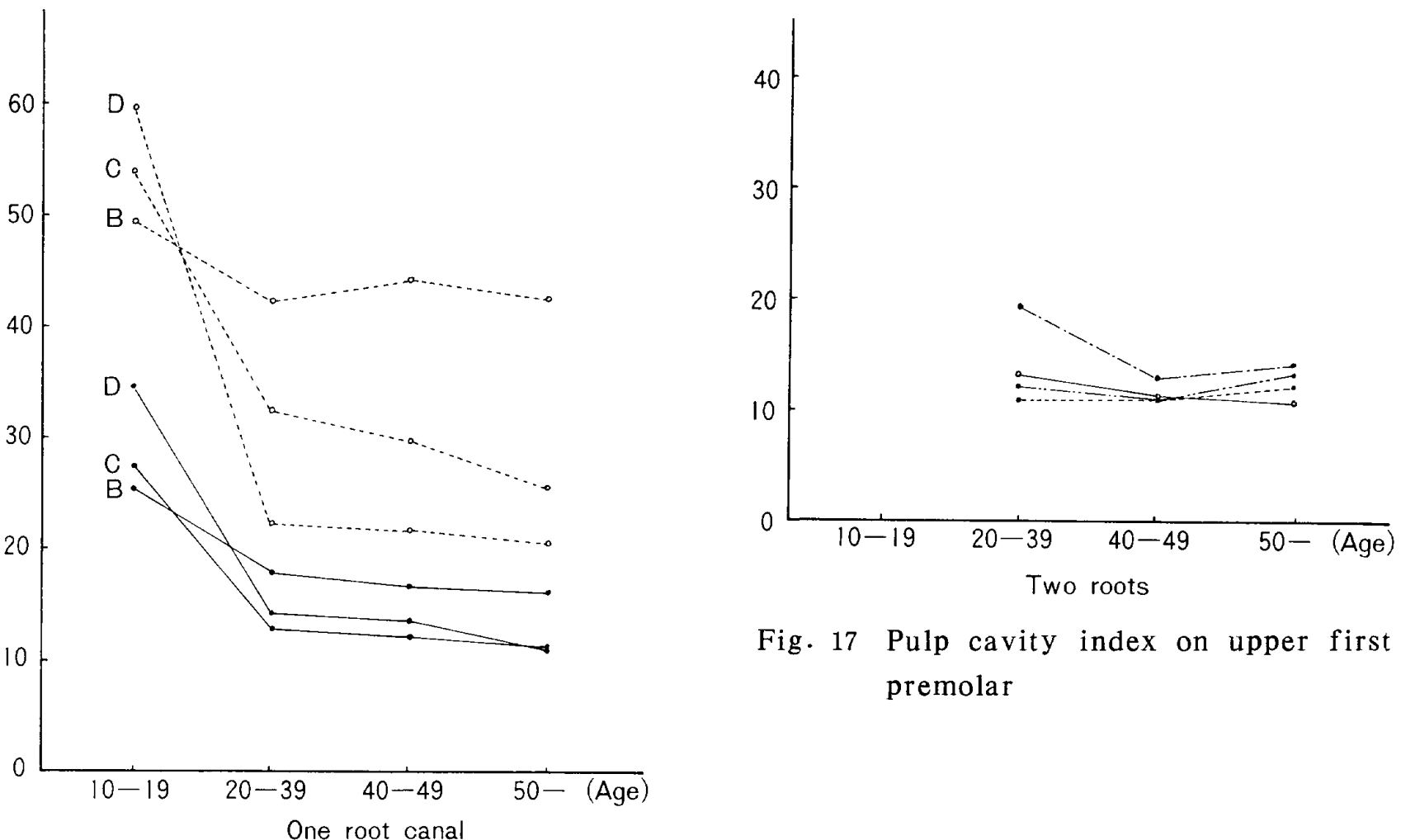

Fig. 17 Pulp cavity index on upper first premolar

Fig. 15 Pulp cavity index on upper first premolar

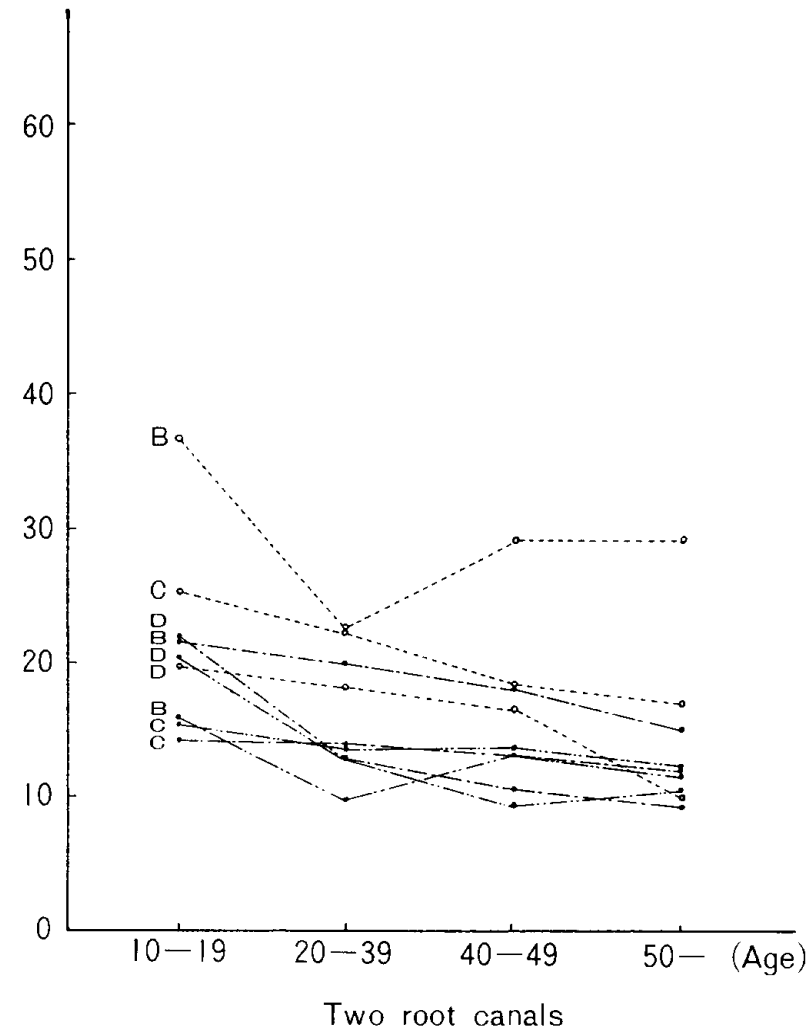

Fig. 16 Pulp cavity index on upper first premolar

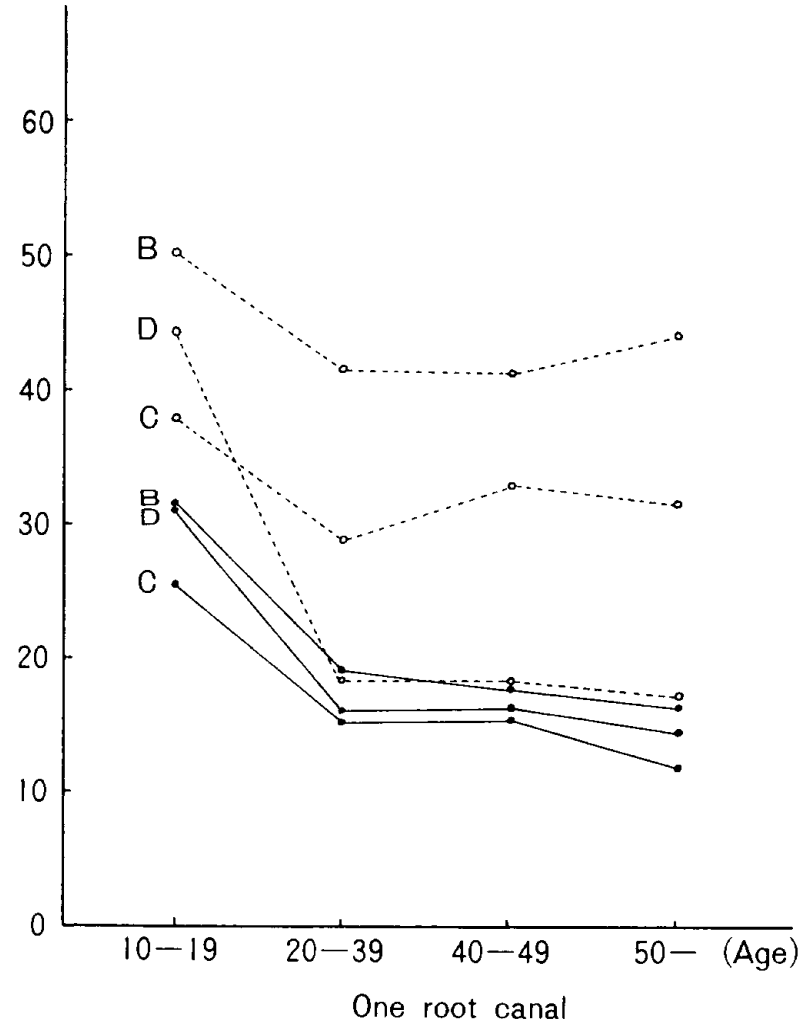

Fig. 18 Pulp cavity index on upper second premolar 
Table 22

Diameter of pulp cavity on upper second premolar

$(\mathrm{mm})$

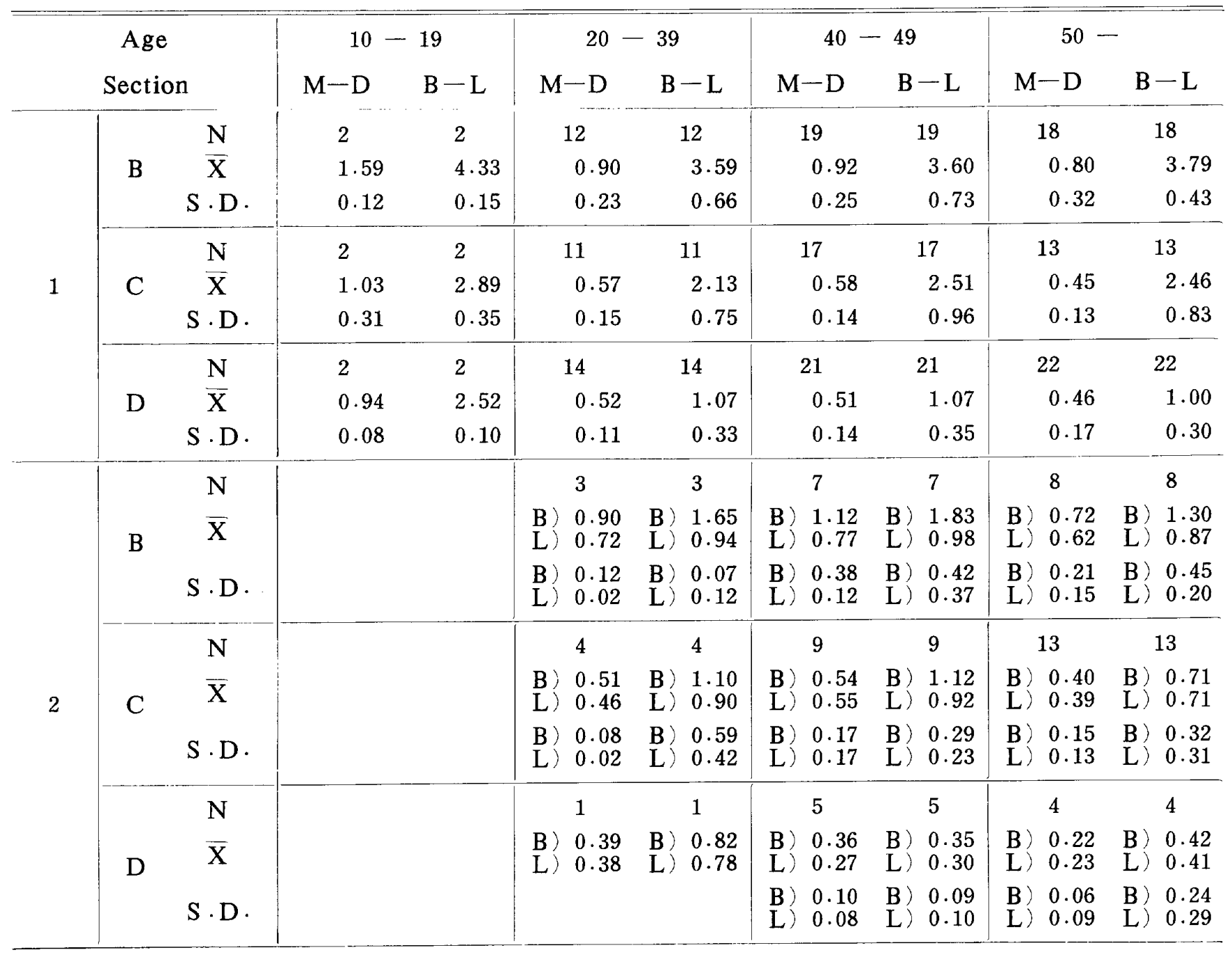


Table 23 Pulp cavity index on upper second premolar

\begin{tabular}{|c|c|c|c|c|c|c|c|c|c|c|}
\hline \multirow{2}{*}{\multicolumn{3}{|c|}{$\begin{array}{c}\text { Age } \\
\text { Section }\end{array}$}} & \multicolumn{2}{|c|}{$10-19$} & \multicolumn{2}{|c|}{$20-39$} & \multicolumn{2}{|c|}{$40-49$} & \multicolumn{2}{|c|}{$50-$} \\
\hline & & & $M-D$ & $B-L$ & $M-D$ & $B-L$ & $M-D$ & $B-L$ & $M-D$ & $B-L$ \\
\hline \multirow{9}{*}{1} & & $N$ & 2 & 2 & 12 & 12 & 19 & 19 & 18 & 18 \\
\hline & B & $\bar{X}$ & 31.59 & 50.18 & 18.47 & 41.52 & 17.87 & 41.27 & 16.40 & 43.92 \\
\hline & & S.D. & 1.73 & 2.87 & 4.54 & 7.06 & 1.92 & 7.61 & 5.94 & 3.63 \\
\hline & & $\mathrm{N}$ & 2 & 2 & 11 & 11 & 17 & 17 & 13 & 13 \\
\hline & C & $\bar{X}$ & 25.61 & 37.87 & 15.28 & 28.89 & 15.32 & 32.92 & 11.79 & 31.55 \\
\hline & & S.D. & 5.90 & 3.38 & 4.09 & 8.90 & 3.14 & 11.19 & 2.66 & 9.22 \\
\hline & & $\mathrm{N}$ & 2 & 2 & 14 & 14 & 21 & 21 & 22 & 22 \\
\hline & D & $\mathrm{X}$ & 31.49 & 44.35 & 16.03 & 18.31 & $16 \cdot 34$ & 18.19 & 14.69 & 16.97 \\
\hline & & $\mathrm{S} \cdot \mathrm{D}$. & 7.27 & 14.79 & 3.08 & 5.35 & 3.94 & 5.14 & 5.19 & 3.65 \\
\hline \multirow{9}{*}{2} & & $\mathrm{~N}$ & & & 3 & 3 & 7 & 7 & 8 & 8 \\
\hline & B & $\bar{X}$ & & & \begin{tabular}{l|l} 
B & 19.08 \\
L & 15.06
\end{tabular} & 31.16 & $\begin{array}{ll}\text { B } & 21.16 \\
\text { L } & 14.54\end{array}$ & 30.05 & $\begin{array}{l:l}\text { B } & 14.05 \\
\text { L } & 12.03\end{array}$ & 24.11 \\
\hline & & $S \cdot D$ & & & $\begin{array}{l}\text { B) } 3.24 \\
\text { L) } 1.24\end{array}$ & 0.48 & $\begin{array}{l}\text { B) } 8.04 \\
\text { L) } 2.79\end{array}$ & $7 \cdot 36$ & 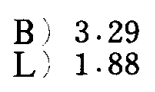 & 5.82 \\
\hline & & $\mathrm{N}$ & & & 4 & 4 & 9 & 9 & 13 & 13 \\
\hline & C & $X$ & & & $\begin{array}{l}\text { B } \\
\text { L } \\
13.41 \\
13.27\end{array}$ & 25.02 & $\begin{array}{ll}\text { B } & 13.60 \\
\text { L } & 14.43\end{array}$ & 25.27 & 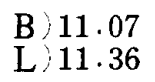 & 17.59 \\
\hline & & S.D. & & & $\begin{array}{l}\text { B) } 2.24 \\
\text { L) } 0.81\end{array}$ & 13.86 & $\begin{array}{l}\text { B) } 3.72 \\
\text { L } \\
4.35\end{array}$ & 4.89 & $\begin{array}{l}\text { B) } 3.32 \\
\text { L) } 3.67\end{array}$ & 6.35 \\
\hline & & $\mathrm{N}$ & & & 1 & 1 & 5 & 5 & 4 & 4 \\
\hline & D & $\mathrm{X}$ & & & $\begin{array}{l}\text { B } \\
\text { L } \\
13.58 \\
13.06\end{array}$ & 24.73 & $\begin{array}{ll}\text { B } & 13.06 \\
\text { L } & 11.19\end{array}$ & 11.04 & 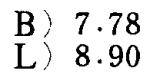 & $14 \cdot 30$ \\
\hline & & $S \cdot D$ & & & & & $\begin{array}{l}\text { B) } 2.38 \\
\text { L) } 2.43\end{array}$ & 2.65 & $\begin{array}{l}\text { B) } 2.32 \\
\text { L) } 2.25\end{array}$ & 7.01 \\
\hline
\end{tabular}

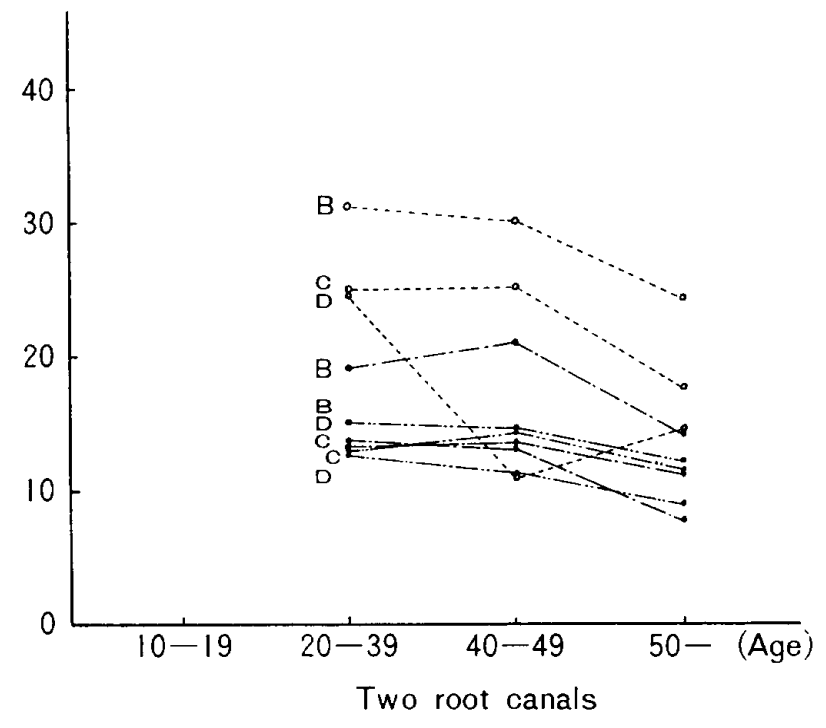

Fig. 19 Pulp cavity index on upper second premolar
D各部の近遠心径，煩舌径ともに增齢に伴い減少が認め られるが, 特に 10 才代から $20 \cdot 30$ 才代への変化が著し く，B部の近遠心径とC・D部の近遠心径，煩舌径にお いては，1\%以下の危険率で有意差がみられた。

根管示数は，表25および図20亿示すとおりである，10 才代から20・30才代への年踰的変化が著しく，B 部の煩 舌径を除いた他の部では，すべて $1 \%$ 以下の危険率で有 意差が諗められた，20・30才代以降では，減少傾向は緩 かであった。

4. 下顎第 2 小臼歯

この歯の計測成績は，丧26亿示すとおりである，B・ $\mathrm{C} \cdot \mathrm{D}$ 各部とも增跘的に減少傾向が琶められるが，特に $10 才$ 代から $20 \cdot 30$ 才代への変化が顕著で， B 部の近遠心 径， $C$ 部の煩舌径ならびに，D部の近遠心径および煩舌 径では有意の差がみられた。また， C 部の $20 ・ 30$ 才代と 40 才代との間の煩舌径およびB部の 40 才代と 50 才以上と 
Table 24

Diameter of pulp cavity on lower first premolar

$(\mathrm{mm})$

\begin{tabular}{|c|c|c|c|c|c|c|c|c|c|c|}
\hline \multirow{2}{*}{\multicolumn{3}{|c|}{$\begin{array}{c}\text { Age } \\
\text { Section }\end{array}$}} & \multicolumn{2}{|c|}{$10-19$} & \multicolumn{2}{|c|}{$20-39$} & \multicolumn{2}{|c|}{$40-49$} & \multicolumn{2}{|c|}{$50-$} \\
\hline & & & $M-D$ & $B-L$ & $M-D$ & $B-L$ & $M-D$ & $B-L$ & $M-D$ & $B-L$ \\
\hline \multirow{9}{*}{1} & & $\mathrm{~N}$ & 19 & 19 & 14 & 14 & 31 & 31 & 30 & 30 \\
\hline & B & $\bar{X}$ & 1.32 & 2.68 & 0.97 & 2.49 & 0.82 & 2.40 & 0.73 & 2.42 \\
\hline & & $S \cdot D$. & 0.22 & 0.60 & 0.21 & 0.23 & 0.20 & 0.42 & 0.16 & 0.38 \\
\hline & & $\mathrm{N}$ & 19 & 19 & 14 & 14 & 31 & 31 & 30 & 30 \\
\hline & C & $\bar{X}$ & 1.20 & 2.77 & 0.72 & 1.31 & 0.67 & 1.11 & 0.63 & 1.15 \\
\hline & & S.D. & 0.20 & 0.57 & 0.15 & 0.42 & 0.14 & 0.61 & 0.15 & 0.34 \\
\hline & & $\mathrm{N}$ & 19 & 19 & 14 & 14 & 31 & 31 & 30 & 30 \\
\hline & D & $\overline{\mathrm{X}}$ & 1.08 & 2.73 & 0.44 & 0.67 & 0.44 & 0.73 & 0.43 & 0.58 \\
\hline & & S.D & 0.38 & 1.24 & 0.10 & 0.20 & 0.18 & 0.43 & 0.12 & 0.25 \\
\hline
\end{tabular}

Table 25

Pulp cavity index on lower first premolar

\begin{tabular}{|c|c|c|c|c|c|c|c|c|c|c|}
\hline \multirow{2}{*}{\multicolumn{3}{|c|}{$\begin{array}{c}\text { Age } \\
\text { Section }\end{array}$}} & \multicolumn{2}{|c|}{$10-19$} & \multicolumn{2}{|c|}{$20-39$} & \multicolumn{2}{|c|}{$40-49$} & \multicolumn{2}{|c|}{$50-$} \\
\hline & & & $M-D$ & $B-L$ & $M-D$ & $B-L$ & $M-D$ & $B-L$ & $M-D$ & $B-L$ \\
\hline \multirow{9}{*}{1} & & $\mathrm{~N}$ & 19 & 19 & 14 & 14 & 31 & 31 & 30 & 30 \\
\hline & B & $\bar{X}$ & 26.31 & 36.43 & 20.11 & 35.64 & $17 \cdot 26$ & 34.75 & 15.42 & 34.43 \\
\hline & & S.D. & 4.19 & 5.54 & 4.22 & 3.44 & 3.59 & 4.74 & 3.01 & 4.37 \\
\hline & & $\mathrm{N}$ & 19 & 19 & 14 & 14 & 31 & 31 & 30 & 30 \\
\hline & $\mathrm{C}$ & $\overline{\mathrm{X}}$ & 29.94 & $41 \cdot 32$ & 19.61 & 21.92 & 17.66 & 17.46 & 16.81 & 18.13 \\
\hline & & S.D. & 3.98 & 7.23 & 3.75 & 6.63 & 3.46 & 8.18 & 3.00 & 5.14 \\
\hline & & $\mathrm{N}$ & 19 & 19 & 14 & 14 & 31 & 31 & 30 & 30 \\
\hline & D & $\bar{X}$ & 33.55 & 48.46 & 16.31 & $15 \cdot 21$ & 14.63 & 14.59 & 12.91 & 12.59 \\
\hline & & S.D. & 8.74 & 16.55 & 2.68 & 3.15 & 4.87 & 7.32 & 2.63 & 6.13 \\
\hline
\end{tabular}

Table 26

Diameter of pulp cavity on lower second premolar

$(\mathrm{mm})$

\begin{tabular}{|c|c|c|c|c|c|c|c|c|c|c|}
\hline \multirow{2}{*}{\multicolumn{3}{|c|}{$\begin{array}{c}\text { Age } \\
\text { Section }\end{array}$}} & \multicolumn{2}{|c|}{$10-19$} & \multicolumn{2}{|c|}{$20-39$} & \multicolumn{2}{|c|}{$40-49$} & \multicolumn{2}{|c|}{$50-$} \\
\hline & & & $M-D$ & $B-L$ & $M-D$ & $B-L$ & $M-D$ & $B-L$ & $M-D$ & $B-L$ \\
\hline \multirow{9}{*}{1} & & $\mathbf{N}$ & 4 & 4 & 10 & 10 & 26 & 26 & 27 & 27 \\
\hline & B & $\mathrm{X}$ & 1.43 & 3.00 & 0.98 & 2.74 & 0.93 & 2.56 & 0.78 & 2.51 \\
\hline & & S.D. & 0.13 & 0.58 & 0.20 & 0.40 & 0.20 & 0.60 & 0.20 & 0.71 \\
\hline & & $\mathrm{N}$ & 4 & 4 & 10 & 10 & 26 & 26 & 27 & 27 \\
\hline & $\mathrm{C}$ & $\mathrm{X}$ & 1.12 & 2.56 & 0.98 & 1.41 & 0.78 & 1.00 & 0.67 & 1.21 \\
\hline & & $S \cdot D$ & 0.19 & 0.70 & 0.20 & 0.66 & 0.10 & 0.32 & 0.11 & 0.60 \\
\hline & & $\mathbf{N}$ & 4 & 4 & 10 & 10 & 26 & 26 & 27 & 27 \\
\hline & D & $\overline{\mathrm{X}}$ & 0.84 & 2.15 & 0.48 & 0.71 & 0.45 & 0.56 & 0.45 & 0.66 \\
\hline & & S.D. & 0.16 & 0.76 & 0.19 & 0.35 & 0.12 & 0.20 & 0.15 & 0.26 \\
\hline
\end{tabular}


の閒の近遠心径に有意の差がみられた。

示数值は，表27および図21に示すとおりである１0 代から20・30才代への減少傾向が著しく，B 部の近遠心 径ならびにC・D部の近遠心径，煩舌径において有意の 差が詰められた。それ以後の増秢的変化は著明でなかっ た。

II . 幅擪示数

A. 外径
1. 上額第 1 小曰雨

外径における幅厚示数は，表28に示すとおりである。

A 部では増粭的にほとんど美はみられなかった。1根管 菌の B・C・D各部では，D部の 10 才代から $20 \cdot 30$ 才代 にかけて有意差がみられた以外，ほとんど差はなかっ た。 2 根管菌および 2 根菌における変化も活とんどみら れなかった。

2 . 上䫑第 2 小臼歯

Table 27 Pulp cavity index on lower second premolar

\begin{tabular}{|c|c|c|c|c|c|c|c|c|c|c|}
\hline \multirow{2}{*}{\multicolumn{3}{|c|}{$\begin{array}{c}\text { Age } \\
\text { Section }\end{array}$}} & \multicolumn{2}{|c|}{$10-19$} & \multicolumn{2}{|c|}{$20-39$} & \multicolumn{2}{|c|}{$40-49$} & \multicolumn{2}{|c|}{$50-$} \\
\hline & & & $M-D$ & $B-L$ & $M-D$ & $B-L$ & $M-D$ & $B-L$ & $M-D$ & $B-L$ \\
\hline \multirow{9}{*}{1} & & $\mathrm{~N}$ & 4 & 4 & 10 & 10 & 26 & 26 & 27 & 27 \\
\hline & B & $\bar{X}$ & 28.72 & 41.20 & 20.24 & 38.35 & 18.66 & 35.76 & 15.81 & 34.15 \\
\hline & & S.D. & 2.26 & 5.63 & 3.18 & 4.10 & 3.61 & $7 \cdot 20$ & 4.01 & 8.82 \\
\hline & & $\mathrm{N}$ & 4 & 4 & 10 & 10 & 26 & 26 & 27 & 27 \\
\hline & C & $\bar{X}$ & 28.82 & 38.46 & 20.23 & 22.70 & 20.19 & 16.66 & 17.34 & 19.07 \\
\hline & & S.D. & 3.33 & $10 \cdot 23$ & 4.07 & 8.77 & 2.21 & 4.44 & 2.98 & 8.25 \\
\hline & & $\mathrm{N}$ & 4 & 4 & 10 & 10 & 26 & 26 & 27 & 27 \\
\hline & D & $\overline{\mathrm{X}}$ & 29.07 & 44.82 & 15.33 & 14.44 & 14.44 & $12 \cdot 16$ & 13.74 & 13.33 \\
\hline & & S.D. & 4.53 & 15.10 & 3.95 & 5.10 & 3.37 & 3.15 & 3.40 & 3.19 \\
\hline
\end{tabular}

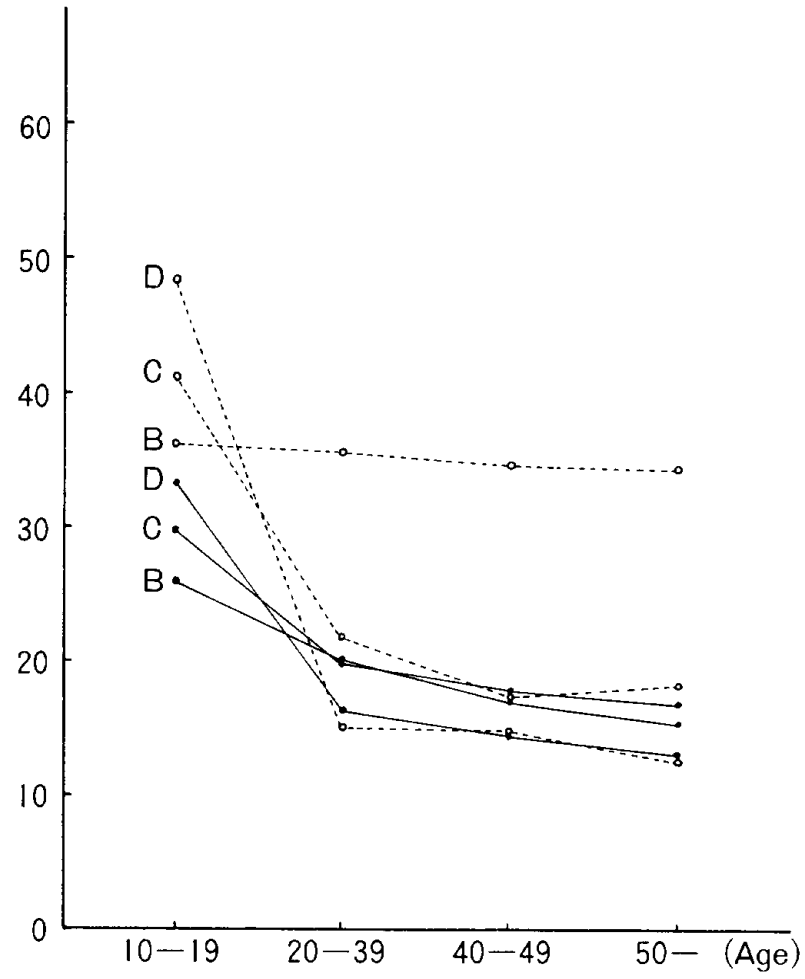

Fig. 20 Pulp cavity index on lower first premolar

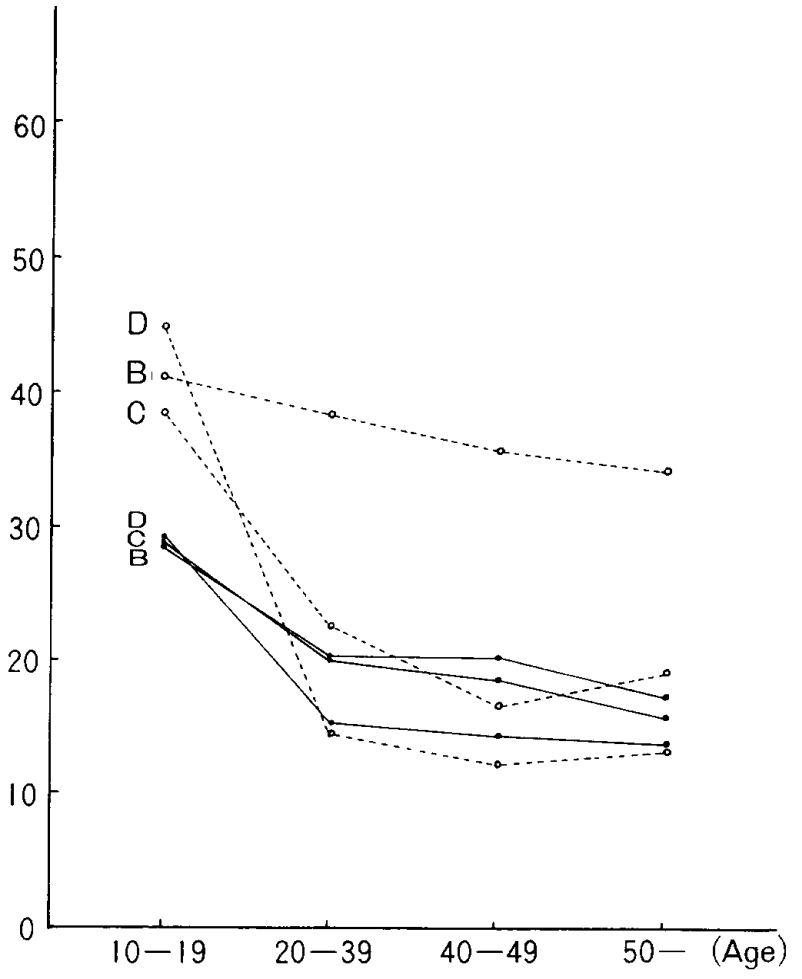

Fig. 21 Pulp cavity index on lower second premolar 
Table 28 Breadth-thickness index of outside on upper first premolar

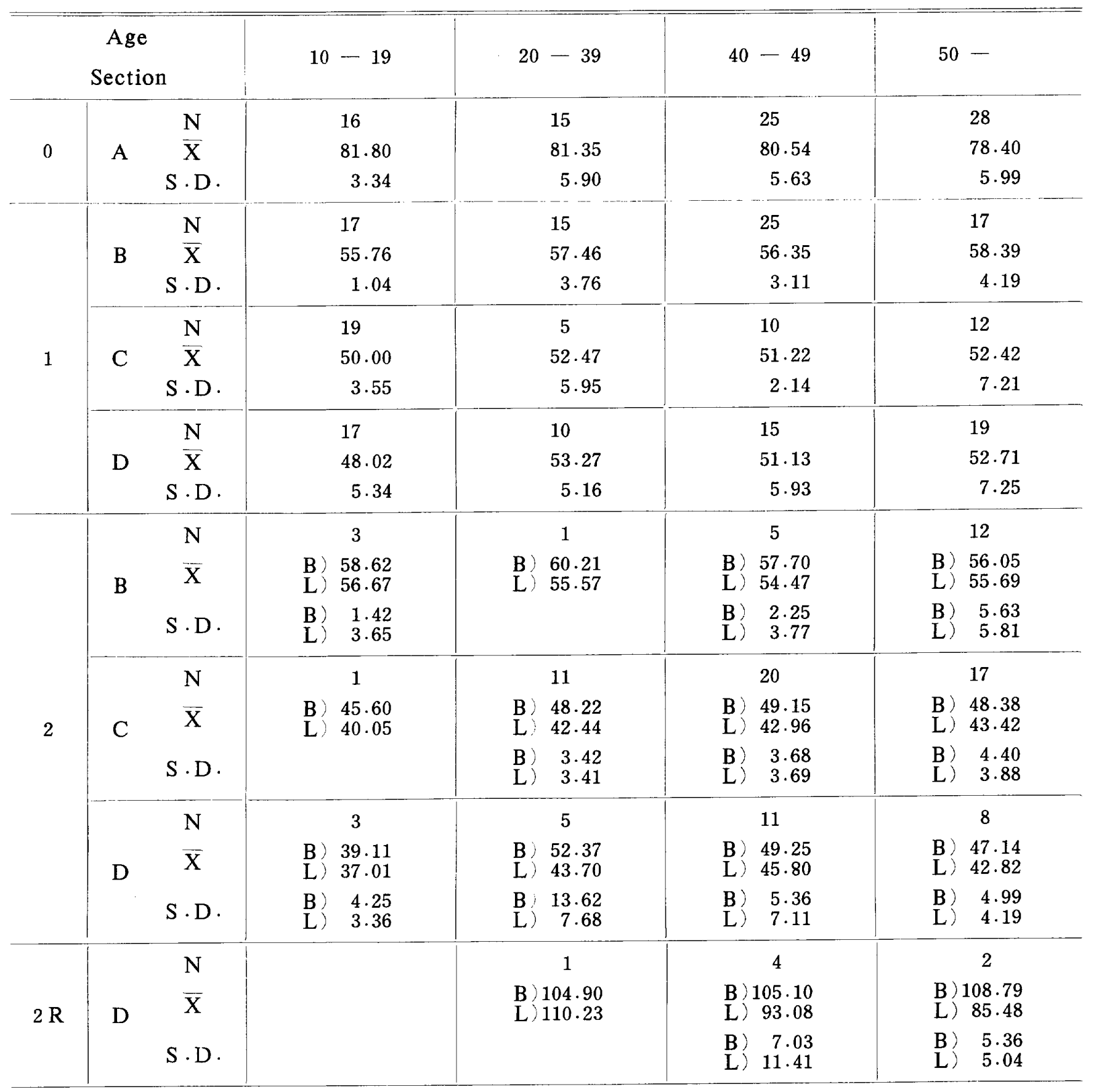


Table 29

Breadth-thickness index of outside on upper second premolar

\begin{tabular}{|c|c|c|c|c|c|c|}
\hline \multicolumn{3}{|c|}{$\begin{array}{c}\text { Age } \\
\text { Section }\end{array}$} & $10-19$ & $20-39$ & $40-49$ & $50-$ \\
\hline \multirow{4}{*}{1} & A & $\begin{array}{c}\frac{N}{X} \\
S \cdot D .\end{array}$ & $\begin{array}{c}2 \\
77.55 \\
4.26\end{array}$ & $\begin{array}{l}14 \\
76.31 \\
3.00\end{array}$ & $\begin{array}{l}26 \\
76.78 \\
3.62\end{array}$ & $\begin{array}{l}24 \\
74.41 \\
4.07\end{array}$ \\
\hline & B & $\begin{array}{c}\frac{N}{X} \\
S \cdot D .\end{array}$ & $\begin{array}{c}2 \\
58.15 \\
1.06\end{array}$ & $\begin{array}{l}12 \\
56.42 \\
2.90\end{array}$ & $\begin{array}{l}19 \\
57.20 \\
6.45\end{array}$ & $\begin{array}{l}18 \\
56.47 \\
4.92\end{array}$ \\
\hline & $\mathrm{C}$ & $\begin{array}{c}\frac{N}{X} \\
S \cdot D .\end{array}$ & $\begin{array}{l}2 \\
52.15 \\
2.04\end{array}$ & $\begin{array}{r}11 \\
51.60 \\
3.30\end{array}$ & $\begin{array}{l}17 \\
50.19 \\
4.56\end{array}$ & $\begin{array}{l}13 \\
49.49 \\
5.04\end{array}$ \\
\hline & $\mathrm{D}$ & $\begin{array}{c}\frac{N}{X} \\
S \cdot D .\end{array}$ & $\begin{array}{r}2 \\
53.79 \\
4.96\end{array}$ & $\begin{array}{l}14 \\
56.11 \\
5.55\end{array}$ & $\begin{array}{l}21 \\
54 \cdot 20 \\
6.51\end{array}$ & $\begin{array}{l}22 \\
54.81 \\
5.74\end{array}$ \\
\hline \multirow{3}{*}{2} & B & $\begin{array}{c}\mathrm{N} \\
\bar{X} \\
\mathrm{~S} \cdot \mathrm{D} .\end{array}$ & & $\begin{array}{l}3 \\
\text { B) } 57.14 \\
\text { L) } 57.65 \\
\text { B) } 2.03 \\
\text { L) } 1.22\end{array}$ & $\begin{array}{c} \\
\text { B) } 56.90 \\
\text { L) } 56.90 \\
\text { B) } 4.24 \\
\text { L) } 4.24\end{array}$ & $\begin{array}{c}8 \\
\text { B) } 56.55 \\
\text { L) } 56.44 \\
\text { B) } 5.15 \\
\text { L) } 5.09\end{array}$ \\
\hline & $\mathrm{C}$ & $\begin{array}{c}\frac{N}{X} \\
S \cdot D .\end{array}$ & & $\begin{array}{l}4 \\
\text { B) } 47.00 \\
\text { L) } 42.61 \\
\text { B) } 2.94 \\
\text { L) } 2.29\end{array}$ & $\begin{array}{lr} & 9 \\
\text { B } & 48.24 \\
\text { L) } & 45.52 \\
\text { B) } & 3.59 \\
\text { L) } & 3.79\end{array}$ & $\begin{array}{l}13 \\
\text { B) } 45.12 \\
\text { L) } \\
43.32 \\
\text { B) } 5.73 \\
\text { L) } \\
2.95\end{array}$ \\
\hline & $\mathrm{D}$ & $\begin{array}{c}\mathrm{N} \\
\bar{X} \\
\mathrm{~S} \cdot \mathrm{D} .\end{array}$ & & $\begin{array}{c}1 \\
\text { B) } 44.09 \\
\text { L) } 45.26\end{array}$ & 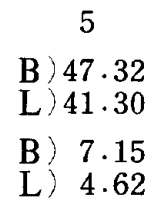 & $\begin{array}{cc} & 4 \\
\text { B } & 51.10 \\
\text { L) } & 46.43 \\
\text { B) } & 2.35 \\
\text { L) } & 4.09\end{array}$ \\
\hline
\end{tabular}

表29のでとく，それはど大きな変化はみられず，A部 の40才代と50才以上との間で有意の差が珰められたに過 ぎない。

\section{3. 下䫑第 1 小臼菌}

表30に示すように，各部とも大きな変化は認められな かった。

\section{4. 下䔛第 2 小四菌}

表31のでとく，ほとんど変化は認められなかった。

B . エナメル質部

各幽におけるエナメル質幅愿示数值の成績は, 表 32 の ごとくである

1. 上䫟第 1 小曰歯

増秢に伴う减少傾向がみられたが，10才代から $20 \cdot 30$
才代への変化と $40 才$ 代から50才以上への変化が，やゃ著 しかった程度で，全体的に大きな変化は認められなかっ た。

\section{2. 上顎第 2 小曰歯}

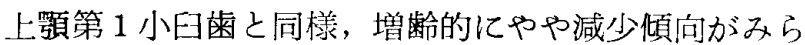
れたが，大きな差はなかった。

3. 下嚬第 1 小E蒾

全体的には，増秢的に減少傾向を表しているが，40才 代から50才以上にかけては増加を示し，5\%以下の危険 率で有意の差が認められた。

4. 下顎第 2 小眊菌

増齢に伴い減少傾问がみられるが，有意の差はなか った。 
Table 30 Breadth-thickness index of outside on lower first premolar

\begin{tabular}{|c|c|c|c|c|c|c|}
\hline \multicolumn{3}{|c|}{$\begin{array}{c}\text { Age } \\
\text { Section }\end{array}$} & $10-19$ & $20-39$ & $40-49$ & $50-$ \\
\hline 0 & A & $\begin{array}{c}\frac{N}{X} \\
S \cdot D .\end{array}$ & $\begin{array}{l}15 \\
97.64 \\
5.39\end{array}$ & $\begin{array}{l}12 \\
94.87 \\
8.61\end{array}$ & $\begin{array}{r}14 \\
90.56 \\
5.45\end{array}$ & $\begin{array}{l}22 \\
91.10 \\
6.34\end{array}$ \\
\hline \multirow{3}{*}{1} & B & $\begin{array}{c}\mathrm{N} \\
\mathrm{X} \\
\mathrm{S} \cdot \mathrm{D} .\end{array}$ & $\begin{array}{l}19 \\
69.29 \\
5.80\end{array}$ & $\begin{array}{l}14 \\
69.00 \\
3.62\end{array}$ & $\begin{array}{l}31 \\
68.48 \\
4.74\end{array}$ & $\begin{array}{l}30 \\
67.60 \\
3.20\end{array}$ \\
\hline & $\mathrm{C}$ & $\begin{array}{c}\frac{N}{X} \\
S \cdot D .\end{array}$ & $\begin{array}{l}19 \\
60.38 \\
5.97\end{array}$ & $\begin{array}{l}14 \\
61.61 \\
5.81\end{array}$ & $\begin{array}{l}31 \\
61.38 \\
6.70\end{array}$ & $\begin{array}{l}30 \\
59.92 \\
3.16\end{array}$ \\
\hline & D & $\begin{array}{c}\frac{N}{X} \\
S \cdot D .\end{array}$ & $\begin{array}{l}19 \\
58.62 \\
6.93\end{array}$ & $\begin{array}{l}14 \\
62.47 \\
6.59\end{array}$ & $\begin{array}{l}31 \\
62.15 \\
8.35\end{array}$ & $\begin{array}{l}30 \\
62.80 \\
4.92\end{array}$ \\
\hline
\end{tabular}

Table 31

Breadth-thickness index of outside on lower second premolar

\begin{tabular}{|c|c|c|c|c|c|c|}
\hline \multicolumn{3}{|c|}{$\begin{array}{c}\text { Age } \\
\text { Section }\end{array}$} & $10-19$ & $20-39$ & $40-49$ & $50-$ \\
\hline 0 & A & $\begin{array}{c}\frac{N}{X} \\
S \cdot D .\end{array}$ & $\begin{array}{c}4 \\
92.96 \\
3.65\end{array}$ & $\begin{array}{c}9 \\
91.44 \\
4 \cdot 35\end{array}$ & $\begin{array}{r}25 \\
89.52 \\
5.00\end{array}$ & $\begin{array}{r}25 \\
87.58 \\
5.16\end{array}$ \\
\hline \multirow{3}{*}{1} & B & $\begin{array}{c}\frac{N}{X} \\
S \cdot D .\end{array}$ & \begin{tabular}{r}
\multicolumn{1}{l}{} \\
68.72 \\
2.79
\end{tabular} & $\begin{array}{l}10 \\
67.66 \\
3.88\end{array}$ & $\begin{array}{l}26 \\
69.75 \\
6.87\end{array}$ & $\begin{array}{l}27 \\
67.46 \\
4.13\end{array}$ \\
\hline & $\mathrm{C}$ & $\begin{array}{c}\frac{N}{X} \\
S \cdot D .\end{array}$ & \begin{tabular}{r}
\multicolumn{4}{c}{} \\
57.96 \\
4.30
\end{tabular} & $\begin{array}{l}10 \\
62.78 \\
5.83\end{array}$ & $\begin{array}{l}26 \\
65.32 \\
4.94\end{array}$ & $\begin{array}{l}27 \\
62.47 \\
5.26\end{array}$ \\
\hline & $\mathrm{D}$ & $\begin{array}{c}\frac{N}{X} \\
S \cdot D .\end{array}$ & \begin{tabular}{r}
\multicolumn{1}{c}{} \\
60.04 \\
3.43
\end{tabular} & $\begin{array}{l}10 \\
66.48 \\
7.61\end{array}$ & $\begin{array}{l}26 \\
67.45 \\
14.46\end{array}$ & $\begin{array}{l}27 \\
67.47 \\
6.33\end{array}$ \\
\hline
\end{tabular}


Table $32 \quad$ Breadth-thickness index of enamel

\begin{tabular}{|c|c|c|c|c|c|c|}
\hline \multicolumn{3}{|c|}{$\begin{array}{c}\text { Age } \\
\text { Section }\end{array}$} & $10-19$ & $20-39$ & $40-49$ & $50-$ \\
\hline \multirow{4}{*}{0} & $\underline{P_{1}}$ & $\begin{array}{c}\frac{N}{X} \\
S \cdot D .\end{array}$ & $\begin{array}{l}16 \\
87.92 \\
14.09\end{array}$ & $\begin{array}{l}15 \\
83.11 \\
10.53\end{array}$ & $\begin{array}{l}25 \\
83.56 \\
12.18\end{array}$ & $\begin{array}{l}28 \\
79.78 \\
14.18\end{array}$ \\
\hline & $\underline{\mathrm{P}_{2}}$ & $\begin{array}{c}\frac{N}{X} \\
S \cdot D\end{array}$ & $\begin{array}{r}2 \\
85.93 \\
4.25\end{array}$ & $\begin{array}{r}14 \\
82.61 \\
7.86\end{array}$ & $\begin{array}{r}26 \\
83.28 \\
8.62 \\
\end{array}$ & $\begin{array}{l}24 \\
77.11 \\
9.45 \\
\end{array}$ \\
\hline & $\overline{\mathrm{P}_{1}}$ & $\begin{array}{c}\frac{N}{X} \\
S \cdot D\end{array}$ & $\begin{array}{r}15 \\
86.36 \\
9.07\end{array}$ & $\begin{array}{l}12 \\
86.66 \\
11.71\end{array}$ & $\begin{array}{l}14 \\
79.92 \\
20.23\end{array}$ & $\begin{array}{l}22 \\
91.11 \\
10.70\end{array}$ \\
\hline & $\overline{\mathrm{P}_{2}^{-}}$ & $\begin{array}{c}\frac{N}{X} \\
S \cdot D\end{array}$ & $\begin{array}{c}4 \\
99.00 \\
10.25\end{array}$ & $\begin{array}{c}9 \\
96.66 \\
15.05\end{array}$ & $\begin{array}{l}25 \\
90.88 \\
21.40\end{array}$ & $\begin{array}{l}25 \\
93.82 \\
18.13\end{array}$ \\
\hline
\end{tabular}

\section{C. 象牙質部}

\section{1. 上顎第 1 小四柬}

表33に示すごとく，A部では年秢的な変化はあまり認 められず， 1 根管雨の B 部でも大きな変化は小していな いが，C・D部では，10才代から20・30才代にかけて娍 少を亦し， $1 \%$ 以下の危険率でもって有意の差がみられ た. 2 根管菓では, 各部とも多少の年柃的変化はある が，それほど大きな差異は認められなかった。2 根歯に ついても，ほとんど変化はみられなかった。

2. 上顎第 2 小目菊

表34に示すでとく，A部では堌齢的な変化はほとんど なく， 1 根管雨においてもそれほど大きな変化は認めら れないが，2 根管歯では，C部の煩側部および舌側部で 40 才代から 50 才以上にかけての減少と D部の舌側部で の，40才代から50才以上にかけての增加江有意の差が誌 められた。しかし，その他の年齢群間では大した劣化は なかった。

\section{3. 下顎第 1 小目蒾}

表35に示してあるとおり，增秢に従いA部は減少傾向 がみられ， B 部は増加傾问を示しているが，大きな差は なかった、C・D部では増秢的に娍少傾向を示し，特に 10 才代から $20 \cdot 30$ 才代への変化は著明で， $1 \%$ 以下の危 険率で有意の差を示した。

4. 下顎第 2 小目霖

表36に示すように，D部に扔いて10才代から20・30才 代にかけての減少傾问が， $5 \%$ 以下の危険率で有意の差
をみせている以外，各部とも各年湅群間の変化は少なか った。

D. セメント質部

1. 上顎第 1 小臼秚

し類のセメント質の幅桪示数は，表37に示すごとくで

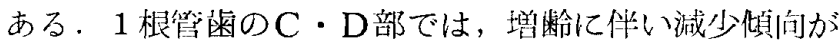
認められる. D部の 40 才代から 50 才以上にかけての変化 のみは，逆に増加を示しているが，有意の差はなかっ た。 2 根管雨においては，C・D部ともに堌秢的に著し い增減を示しているが，有意の差は諗められなかった。 2 根蒾では，增羚に伴い20・30才代から 40 才代にかけて は娍少傾问芷，40才代加ら50戈以上へ加けては增加傾!

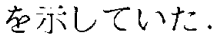

2. 上顎第 2 小曰臿来

1 根管蒾においては，C部は增秢に従い娍少傾治がみ

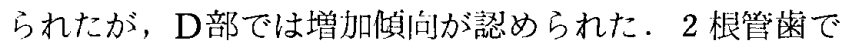
は，C部は20・30才代から40才代にかけては增加を示 し，40才代から50才以上までは減少を示しており，D部 においては増粭的に増加傾向が認められた。しかし，い ずれも有意の差は認められなかった。

3. 下顎第 1 小曰柬

下䫫小曰菌の幅厚示数は，表38のごとくである．C部 の増秢的変化は，上影第 1 小曰雪に類似した減少做问を 示し， D部は増路に伴う增減が著しくみられたが，有意 の差はなかった。

4. 下顎第 2 小曰蒌 
Table 33

Breadth-thickness index of dentin on upper first premolar

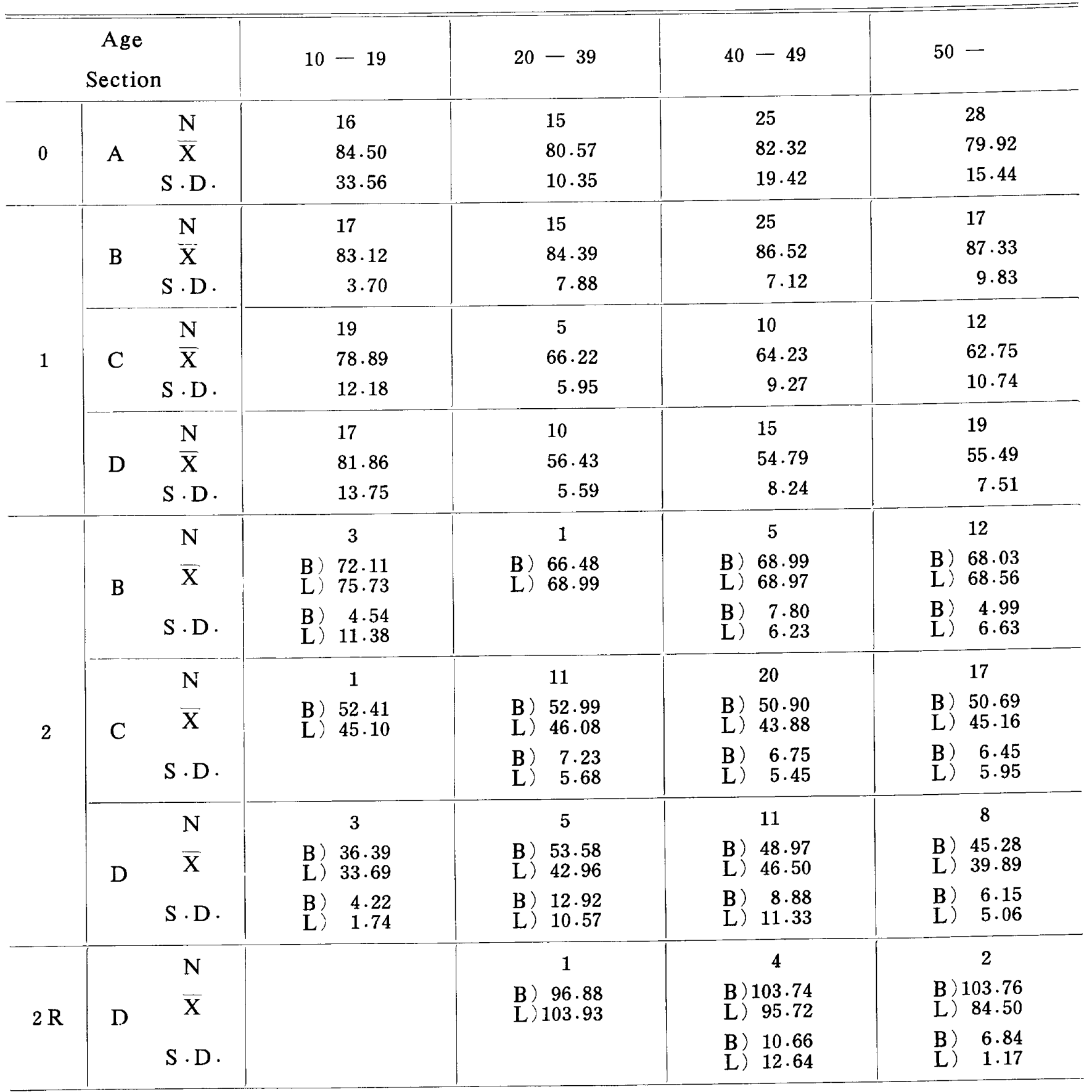


Table 34 Breadth-thickness index of dentin on upper second premolar

\begin{tabular}{|c|c|c|c|c|c|c|}
\hline \multicolumn{3}{|c|}{$\begin{array}{c}\text { Age } \\
\text { Section }\end{array}$} & $10-19$ & $20-39$ & $40-49$ & $50-$ \\
\hline 0 & A & $\begin{array}{c}\frac{N}{X} \\
S \cdot D \cdot\end{array}$ & $\begin{array}{r}2 \\
73.73 \\
2.60\end{array}$ & $\begin{array}{r}14 \\
73.22 \\
4.51\end{array}$ & $\begin{array}{l}26 \\
72.90 \\
4.48 \\
\end{array}$ & $\begin{array}{l}24 \\
72.82 \\
5.41\end{array}$ \\
\hline \multirow{3}{*}{1} & B & $\begin{array}{c}\mathrm{N} \\
\bar{X} \\
S \cdot D\end{array}$ & \begin{tabular}{r}
\multicolumn{2}{c}{} \\
79.96 \\
6.19
\end{tabular} & $\begin{array}{l}12 \\
80.52 \\
10.85\end{array}$ & $\begin{array}{r}19 \\
81.29 \\
7.78\end{array}$ & $\begin{array}{l}18 \\
84.40 \\
6.61\end{array}$ \\
\hline & $\mathrm{C}$ & $\begin{array}{c}\frac{N}{X} \\
S \cdot D\end{array}$ & $\begin{array}{r}2 \\
61.76 \\
1.61 \\
\end{array}$ & $\begin{array}{r}11 \\
61.45 \\
9.36\end{array}$ & $\begin{array}{l}17 \\
64.03 \\
12.86 \\
\end{array}$ & $\begin{array}{l}13 \\
63.59 \\
11.18 \\
\end{array}$ \\
\hline & $\mathrm{D}$ & $\begin{array}{c}N \\
\bar{X} \\
S \cdot D\end{array}$ & $\begin{array}{c}2 \\
66.92 \\
27.80\end{array}$ & $\begin{array}{l}14 \\
54.69 \\
6.59\end{array}$ & $\begin{array}{l}21 \\
52.27 \\
5 \cdot 16\end{array}$ & $\begin{array}{l}22 \\
52.77 \\
5.76\end{array}$ \\
\hline \multirow{3}{*}{2} & B & $\begin{array}{c}\mathrm{N} \\
\overline{\mathrm{X}} \\
\mathrm{S} \cdot \mathrm{D}\end{array}$ & & 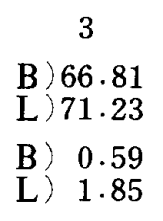 & $\begin{array}{c}7 \\
\text { B) } 66.59 \\
\text { L) } 70.38 \\
\text { B) } 7.34 \\
\text { L) }\end{array}$ & 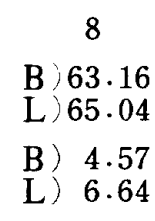 \\
\hline & $\mathrm{C}$ & $\begin{array}{c}\mathrm{N} \\
\bar{X} \\
S \cdot D .\end{array}$ & & $\begin{array}{c}4 \\
\text { B) } 55.13 \\
\text { L) } 48.98 \\
\text { B) } 12.35 \\
\text { L } \\
11.76\end{array}$ & $\begin{array}{l}9 \\
\text { B) } 55.62 \\
\text { L) } 51.85 \\
\text { B) } 6.58 \\
\text { L) } 7.02 \\
\end{array}$ & 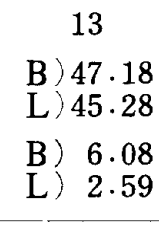 \\
\hline & $\mathrm{D}$ & $\begin{array}{c}\mathrm{N} \\
\bar{X} \\
\mathrm{~S} \cdot \mathrm{D}\end{array}$ & & $\begin{array}{c}1 \\
\text { B) } 48.48 \\
\text { L) } 49.78\end{array}$ & 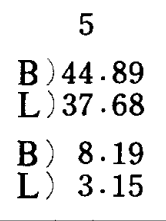 & 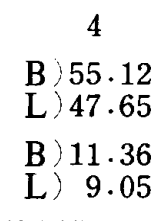 \\
\hline
\end{tabular}


Table $35 \quad$ Breadth-thickness index of dentin on lower first premolar

\begin{tabular}{|c|c|c|c|c|c|c|}
\hline \multicolumn{3}{|c|}{$\begin{array}{c}\text { Age } \\
\text { Section }\end{array}$} & $10-19$ & $20-39$ & $40-49$ & $50-$ \\
\hline 0 & A & $\begin{array}{c}\frac{N}{X} \\
S \cdot D .\end{array}$ & $\begin{array}{r}15 \\
103.90 \\
10.61\end{array}$ & $\begin{array}{l}12 \\
99.82 \\
15.75\end{array}$ & $\begin{array}{r}14 \\
102.48 \\
33.94\end{array}$ & $\begin{array}{l}22 \\
91.62 \\
7.85\end{array}$ \\
\hline \multirow{3}{*}{1} & B & $\begin{array}{c}\frac{N}{X} \\
S \cdot D .\end{array}$ & $\begin{array}{l}19 \\
79.31 \\
6.92\end{array}$ & $\begin{array}{l}14 \\
86.30 \\
6.70\end{array}$ & $\begin{array}{r}31 \\
87.78 \\
6.12\end{array}$ & $\begin{array}{l}30 \\
87.16 \\
7.69\end{array}$ \\
\hline & $\mathrm{C}$ & $\begin{array}{c}\frac{N}{X} \\
S \cdot D .\end{array}$ & $\begin{array}{l}19 \\
72.33 \\
10.05\end{array}$ & $\begin{array}{r}14 \\
62.90 \\
7.79\end{array}$ & $\begin{array}{l}31 \\
61.11 \\
8.96\end{array}$ & $\begin{array}{l}30 \\
59.20 \\
5.59\end{array}$ \\
\hline & $\mathrm{D}$ & $\begin{array}{c}\frac{N}{X} \\
S \cdot D .\end{array}$ & $\begin{array}{l}19 \\
81.41 \\
23.41\end{array}$ & $\begin{array}{r}14 \\
58.98 \\
5.56\end{array}$ & $\begin{array}{l}31 \\
60.02 \\
9.51\end{array}$ & $\begin{array}{l}30 \\
57.97 \\
6.86\end{array}$ \\
\hline
\end{tabular}

Table 36

Breadth-thickness index of dentin on lower second premolar

\begin{tabular}{|c|c|c|c|c|c|c|}
\hline \multicolumn{3}{|c|}{$\begin{array}{c}\text { Age } \\
\text { Section }\end{array}$} & $10-19$ & $20-39$ & $40-49$ & $50-$ \\
\hline 0 & A & $\begin{array}{c}\frac{N}{X} \\
S \cdot D .\end{array}$ & $\begin{array}{c}4 \\
90.19 \\
10.26\end{array}$ & $\begin{array}{c}9 \\
90.85 \\
9.62\end{array}$ & $\begin{array}{l}25 \\
90 \cdot 49 \\
26 \cdot 13\end{array}$ & $\begin{array}{r}25 \\
86.11 \\
8.40\end{array}$ \\
\hline \multirow{3}{*}{1} & B & $\begin{array}{c}\frac{N}{X} \\
S \cdot D .\end{array}$ & 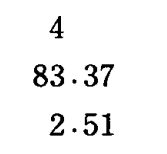 & $\begin{array}{l}10 \\
88.48 \\
7.18\end{array}$ & $\begin{array}{l}26 \\
88.57 \\
10.41\end{array}$ & $\begin{array}{l}27 \\
86.75 \\
8.72\end{array}$ \\
\hline & C & $\begin{array}{c}\frac{N}{X} \\
\text { S.D. }\end{array}$ & $\begin{array}{c}4 \\
68.65 \\
10.04\end{array}$ & $\begin{array}{l}10 \\
65.13 \\
10 \cdot 87\end{array}$ & $\begin{array}{l}26 \\
61.61 \\
5.23\end{array}$ & $\begin{array}{l}27 \\
63.17 \\
8.87\end{array}$ \\
\hline & $\mathrm{D}$ & $\begin{array}{c}\frac{N}{X} \\
S \cdot D .\end{array}$ & $\begin{array}{c}4 \\
79 \cdot 20 \\
17.29\end{array}$ & $\begin{array}{l}10 \\
63.11 \\
7.62\end{array}$ & $\begin{array}{l}26 \\
65.83 \\
7.82\end{array}$ & $\begin{array}{l}27 \\
63.47 \\
6.79\end{array}$ \\
\hline
\end{tabular}


Table 37

Breadth-thickness index of cement on upper premolar

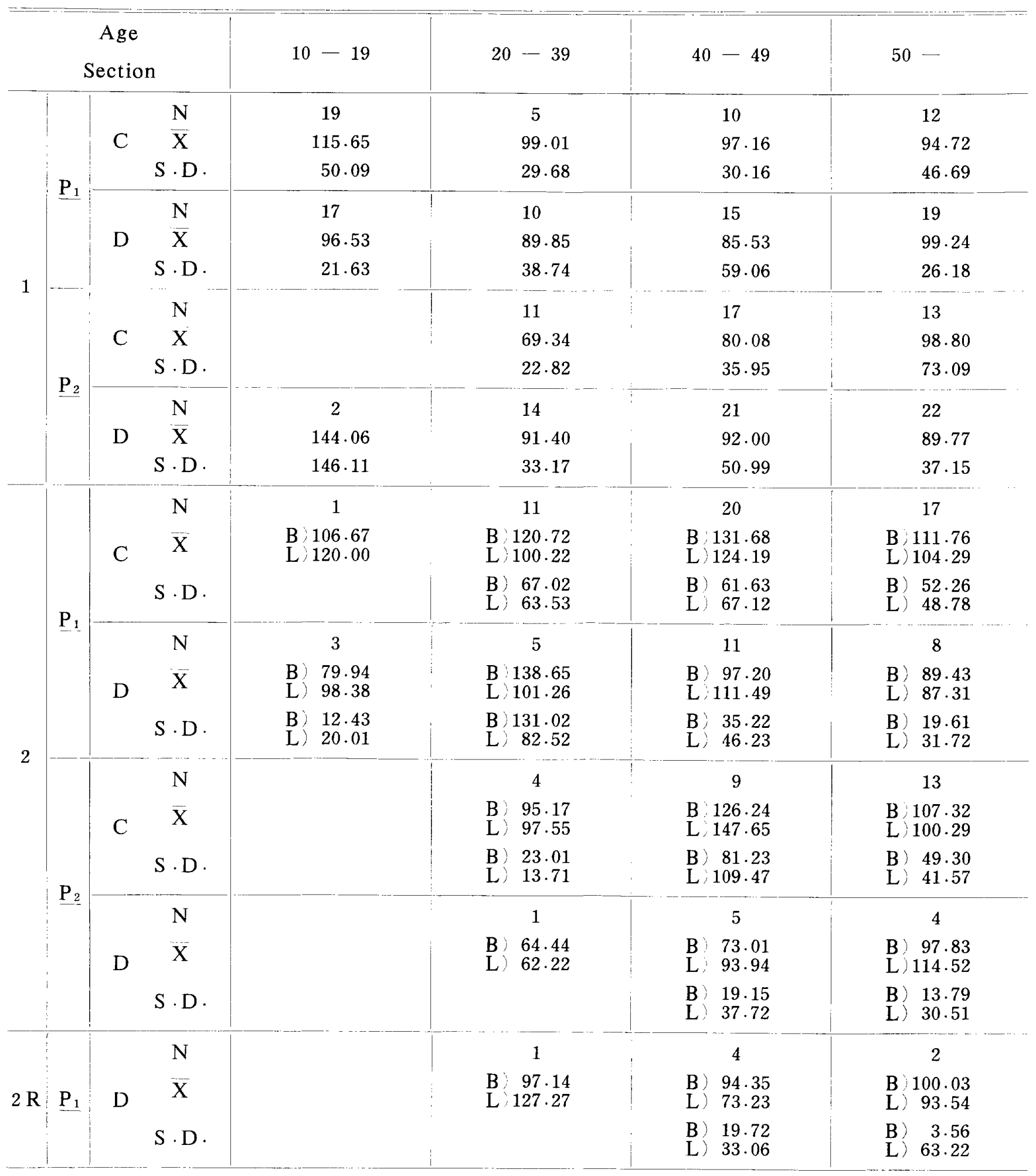


Table 38

Breadth-thickness index of cement on lower premolar

\begin{tabular}{|c|c|c|c|c|c|c|c|}
\hline \multicolumn{4}{|c|}{$\begin{array}{c}\text { Age } \\
\text { Section }\end{array}$} & $10-19$ & $20-39$ & $40-49$ & $50-$ \\
\hline \multirow{4}{*}{1} & \multirow{2}{*}{$\overline{P_{1}}$} & C & $\begin{array}{c}\frac{N}{X} \\
S \cdot D .\end{array}$ & $\begin{array}{r}19 \\
151.67 \\
53.40\end{array}$ & $\begin{array}{r}14 \\
127.56 \\
65.19\end{array}$ & $\begin{array}{r}31 \\
114.59 \\
37.46\end{array}$ & $\begin{array}{r}30 \\
109.39 \\
39.44\end{array}$ \\
\hline & & $\mathrm{D}$ & $\begin{array}{c}\frac{N}{\bar{X}} \\
S \cdot D\end{array}$ & $\begin{array}{r}19 \\
103 \cdot 19 \\
33 \cdot 40\end{array}$ & $\begin{array}{r}14 \\
117.16 \\
75.78\end{array}$ & $\begin{array}{l}31 \\
97.99 \\
31.05\end{array}$ & $\begin{array}{r}30 \\
137.25 \\
78.45\end{array}$ \\
\hline & \multirow{2}{*}{$\overline{\mathrm{P}_{2}}$} & C & $\begin{array}{c}\mathrm{N} \\
\bar{X} \\
S \cdot D\end{array}$ & \begin{tabular}{r}
\multicolumn{1}{c}{} \\
$84 \cdot 34$ \\
0.94
\end{tabular} & $\begin{array}{r}10 \\
149.83 \\
75.28\end{array}$ & $\begin{array}{l}26 \\
122.41 \\
52.45\end{array}$ & $\begin{array}{r}27 \\
118.09 \\
43.66\end{array}$ \\
\hline & & $\mathrm{D}$ & $\begin{array}{c}\frac{N}{X} \\
S \cdot D .\end{array}$ & \begin{tabular}{r}
\multicolumn{1}{c}{4} \\
133.87 \\
36.01
\end{tabular} & $\begin{array}{l}10 \\
120 \cdot 17 \\
58 \cdot 12\end{array}$ & $\begin{array}{r}26 \\
113 \cdot 77 \\
40 \cdot 11\end{array}$ & \begin{tabular}{r}
\multicolumn{1}{c}{27} \\
126.55 \\
56.89
\end{tabular} \\
\hline
\end{tabular}

C部においての10才代から20・30才代への若年者間では 増加を示しているが，以後の変化は減少傾向をみせてお り，D部は10才代から40才代までは減少しているが，50 才以上へかけては増加が認められた，ての函においても 有意差はなかった。

\section{$\mathrm{E}$. 歯髄腔部}

\section{1. 上枵第 1 小臼菡}

幅厚示数は，表39に示すとおりである． 1 根管菊で は，増龆に伴う変化はあまりみられなかったが，D部に おいては，10才代から20・30才代へかけて增加傾问を示 し有意の差が浔められた。 2 根管歯においては，C部は 増粭に従い増加傾向を示しているが，B・D部では各年 粭群間での増減傾问が一定していなかった２根菌は煩 側根では，20・30才代から40才代までは娍少を示し，40 才代以後は増加傾向を示し, また舌側根は増柃的に減少 傾向をみせているが，いずれも有意の差は認められなか った。

\section{2. 上蕷第 2 小罒菌}

表40に示すごとく，1 根管粷でのB 部は堌跉とともに 減少傾向をみせ， $\mathrm{C}$ 部は年粭的変化は少なく，D部は增 加傾向在示している． 2 根管㐘においても，上顎第 1 小 四歯同様，各年柃群間における增減が著しい。しかし， いずれも有意の差が認められるものはなかった。

3. 下影第 1 小罒粜

表41に示すごとくで，B部においては増秢に伴い減少 傾向が認められ，特に10才代から20・30才代にかけて
は，1\%の危険率で有意の差が諗められた・C・D部で は年秢的に堌加傾向を示し，10才代から20・30才代にか けては，1\%以下の危険率で有意の差が認められた。

4. 下影第 2 小曰四迷

表 42 亿示すとおり，B部では増秢とともに減少を示 し, C・D部では増加傾向が認められた。特にB・D部 の10才代から20・30才代へかけては，両者ともに $1 \%$ の 危険率で有意の差を示していた。

\section{総括ならびに考察}

料の生理学的変化のうち主要なものは，咬耗，磨耗， 第 2 象牙質の形成，セメント質の肥昌，歯髄腔の㹨窄な どであり，これらの諸変化はそれぞれ年粭との相関々係 が比較的明白である。その上，歯は人体各組織のうちで 最も硬く，物理的，化学的安定度が高いので，いわゆる 死後変化の 発現が遅く緩かである. そのため法园鑑定 上，しばしば重要な手がかりとなる。また，臨休的にも 各年代における硬組織之雪髄腔の状態を熟知しているこ とは不可久なととである，著者は小四柬の各硬組織と歯 髄腔の増粭的変化ならびにこれら相互間の関係について 調查したが，その結果を総括的にまとめ，考察を加えな がら検討を行う。

I . 各部の計測值からみた年秢的変化

A. 外径

外径は, 増㱓的に大きな変化は認められないが, 多少 の娍少傾向はみられた。すなわち，A部における増粭に 
Table $39 \quad$ Breadth-thickness index of pulp cavity on upper first premolar

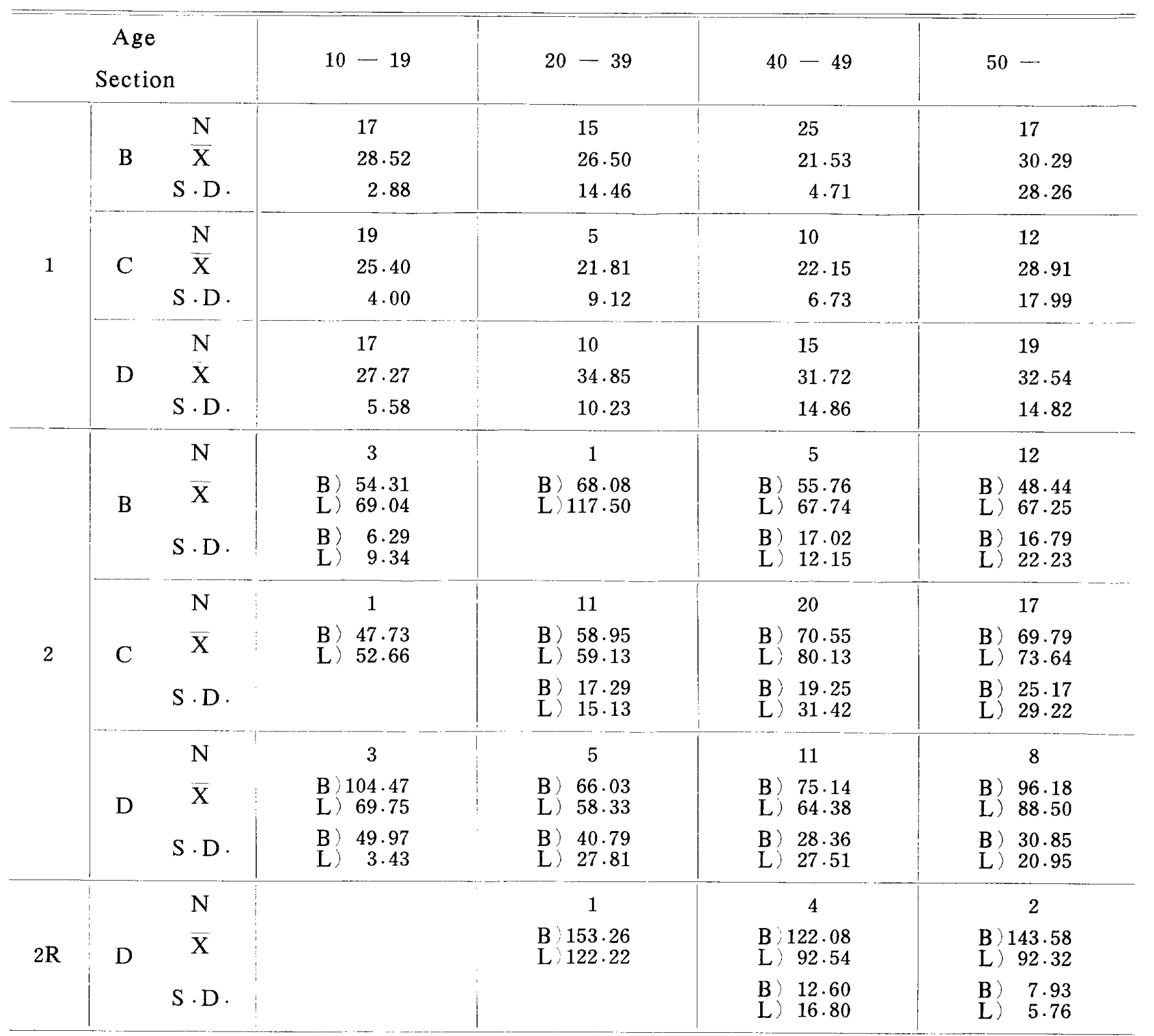


Table 40

Breadth-thickness index of pulp cavity on upper second premolar

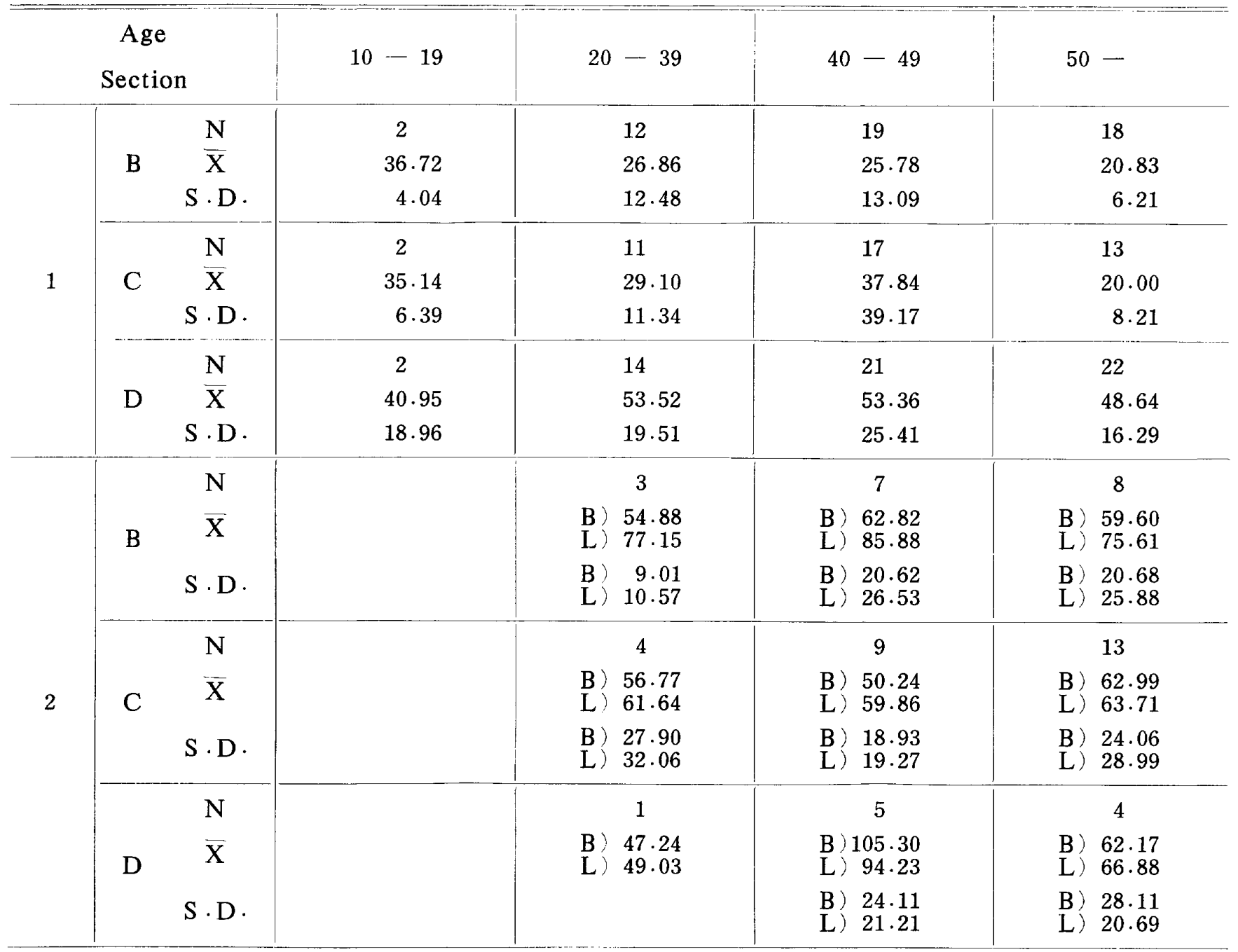

Table 41

Breadth-thickness index of pulp cavity on lower first premolar

\begin{tabular}{|c|c|c|c|c|c|c|}
\hline \multicolumn{3}{|c|}{$\begin{array}{c}\text { Age } \\
\text { Section }\end{array}$} & $10-19$ & $20-39$ & $40-49$ & $50-$ \\
\hline \multirow{3}{*}{1} & B & $\begin{array}{c}\frac{N}{\bar{X}} \\
S \cdot D \cdot\end{array}$ & $\begin{array}{l}19 \\
50.20 \\
6.13\end{array}$ & $\begin{array}{r}14 \\
39.36 \\
9.28\end{array}$ & $\begin{array}{l}31 \\
34.68 \\
9.15\end{array}$ & $\begin{array}{l}30 \\
31.02 \\
6.83\end{array}$ \\
\hline & $\mathrm{C}$ & $\begin{array}{c}\frac{N}{X} \\
S \cdot D\end{array}$ & $\begin{array}{l}19 \\
44.78 \\
9.88\end{array}$ & $\begin{array}{l}14 \\
59.39 \\
19.75\end{array}$ & $\begin{array}{l}31 \\
74.61 \\
31.80\end{array}$ & $\begin{array}{l}30 \\
63.26 \\
34.24\end{array}$ \\
\hline & $\mathrm{D}$ & $\begin{array}{c}\frac{N}{X} \\
\text { S.D. }\end{array}$ & $\begin{array}{l}19 \\
42.57 \\
9.98\end{array}$ & $\begin{array}{l}14 \\
70.16 \\
21.89\end{array}$ & $\begin{array}{l}31 \\
68.90 \\
23.19\end{array}$ & $\begin{array}{l}30 \\
79.50 \\
43.14\end{array}$ \\
\hline
\end{tabular}


Table $42 \quad$ Breadth-thickness index of pulp cavity on lower second premolar

\begin{tabular}{|c|c|c|c|c|c|c|}
\hline \multicolumn{3}{|c|}{$\begin{array}{c}\text { Age } \\
\text { Section }\end{array}$} & $10-19$ & $20-39$ & $40-49$ & $50-$ \\
\hline \multirow{3}{*}{1} & B & $\begin{array}{c}\frac{N}{X} \\
S \cdot D\end{array}$ & $\begin{array}{r}4 \\
48.17 \\
4.60\end{array}$ & $\begin{array}{l}10 \\
35.55 \\
6.73\end{array}$ & $\begin{array}{l}26 \\
39.94 \\
20.86\end{array}$ & $\begin{array}{l}27 \\
33.25 \\
10.81\end{array}$ \\
\hline & $\mathrm{C}$ & $\begin{array}{c}\frac{N}{X} \\
S \cdot D .\end{array}$ & \begin{tabular}{r}
\multicolumn{1}{l}{} \\
42.32 \\
3.64
\end{tabular} & $\begin{array}{l}10 \\
65.30 \\
31.63\end{array}$ & $\begin{array}{l}26 \\
84.75 \\
25.25\end{array}$ & $\begin{array}{l}27 \\
67.19 \\
31.52\end{array}$ \\
\hline & $\mathrm{D}$ & $\begin{array}{c}\frac{N}{X} \\
S \cdot D .\end{array}$ & $\begin{array}{c}4 \\
41.57 \\
10.43\end{array}$ & $\begin{array}{l}10 \\
74.50 \\
18.98\end{array}$ & $\begin{array}{l}26 \\
85.38 \\
20.86\end{array}$ & $\begin{array}{l}27 \\
71.34 \\
17.96\end{array}$ \\
\hline
\end{tabular}

伴う減少倾问は，エナメル質の咬磨耗関連しているも のと思われる。しかし，他方 C・D部では堌加傾问がみ られ，特に根尖に近いD部では著明であった。このこと は，菊池28も同様の結果を報告して扔り，增秢的に第 2 セメント質の添加が增大するためであろう。上顎小罒 柬において，1根管菌， 2 根管歯および 2 根歯の相互閂 での增秢的な変化では，大きな違いはなかった。また， 各菌の近遠心徍之煩舌径を比へてても, その增踰的変化に 大养はなかった。しかしながら，各小曰歯間を比較して

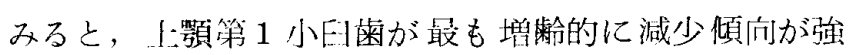
く，上卜頱の第 2 小目菌では有意の差を示すような変化

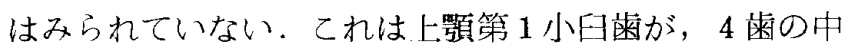
で咬合咀㘉に関与するてとが最も大きいというとと示 唆しているのではないだろうか。

B．エナメル質

各小曰霜とも，近遠心径，煩舌径いずれについても絶

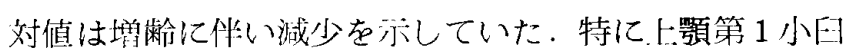
雨が最も大きな変化をみせていたが，てれは外径につい ても同様であり, 外径の增㱓的変化がエナメル質の変異 現象と関係していることを示している，すなわち，咀啲 と咬合の強さに基团しているものと思われる，示数值の

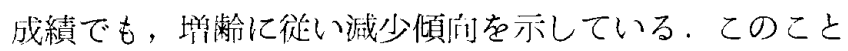
は菌の外径に対して，エナメル質が增踰的に減少を小し ていることであり，要する吃秏，磨耗などの生理的原 因によるものである。

ここで泎目すべきことは，若年者閭での変化に比心゙， 40才代以降での変化が大であるということである。伊東 $(1972)^{30}$ は，歯㵦腔の狭窄とともに歯冠の減少に着目 し，いずれの㐘にも滴応できる測定部位として，エナメ
ル質，冠部象牙質ならびに冠部函髄腔を選び，煩舌的に 歯の中央繸断切片を作製し，X線撮影を行いそれぞれの 面積諳測して面積比を求め, さらに歯冠指数(エナメ 儿質の面積 + 冠部隶髄腔の面積 - - 冠部象牙質の面積 $\times$ 100）在求めている.下表は伊東氏より引用したもので, 中切茵から第 2 大目菌までの 302 本のエナメル質の面積 此の平均值である.

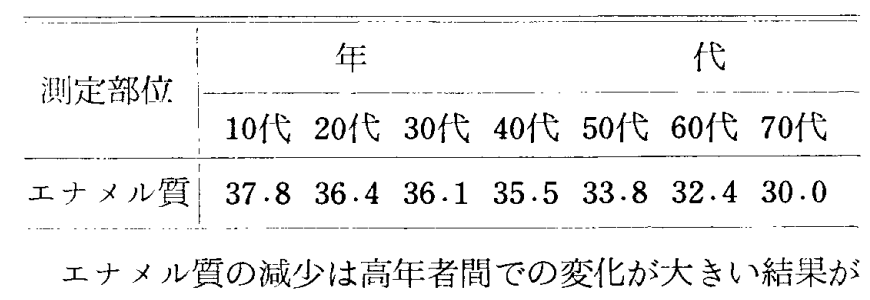
出ている，著者の成績は，歯冠中央部での横断切片によ る計測結果であり,伊東 ${ }^{30}$ ) の実験成績とは異なるが,基 本的には著者の成績之類似している，以上のことから， エナメル質の減少の原囚である咬耗, 磨耗は, 若年者間よ り40才以上からの年代に強く現れることが推測できる.

C. 象牙質

$\mathrm{A}$ 部の計测值による結果では, 10 才代から $20 ・ 30$ 才代 八の減少が浔められたが，乙れは10才代の歯のほとんよ゙ が便宣拔去蒾であるために歯そのものの大きさが，正常 蒾列の雬上り大きいために起こったと思われる.しかし ながら，その他の部では各荬とも培㢼的にやや垍加の傾 向を示していた。乙れを示数值の結果によってみるなら ば，增箚とともに数值の增加が認められ，畨の外径に対 する象牙質の增大がはっきりと見出された。特にB・C ・D部の雨頸部より歯根部において，10才代から20・30 才代への增大が顕著で近遠心径と煩舌径とを此較すると 後者が大であった．また，これらの変化は 1 根管雪が 2 


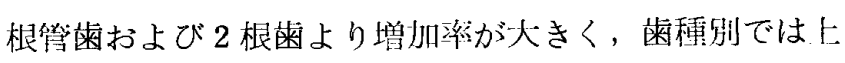

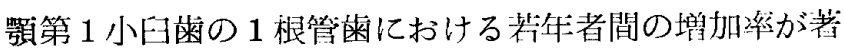
しかった。

象牙質の増加は，第 2 彖牙質の帅成などが原因である が，田所 27) は前雨を使用して歯根部を 4 等分し, 歯頸 部奇り $1 / 4$ \&, 中央部を $\mathrm{B}$, 根端寄り $1 / 4$ をとして, 近 遠心的に象牙質を計測し，近心壁のみを報告している。 この結果においても，増秢に伴い象牙質の増加が認めら れ，特に10才代から30才代までの若年者閒での変化が著 しかったとしている，磯川ら $(1962)^{31 \prime}$ は，犬の米にク サビ状切痕を作ることにより曾髄を刺激し，第 2 象牙質 の発生を促してみたところ，まったく第 2 象牙質の形成 されない柬があったと述べている．また加藤 $(1963)^{32}$ ， 不川ら（1972）331によれば，第 2 象牙質はまったく健全 な曾でも形成されると報告している，以上のてとから， 第 2 象牙兵は単に生理的あるいは病理的刺激のみによっ て起てるものではなく，増柃に伴い，殊に若年者間にお いて必然的に形成されていくものと考えられる。

D.セメント質

絶対值および示数值の成績より，セメント質は堌桠令的 にしだいに増大していくことが認められる．乙れを各柬 種別にみると，上下枵に扔いて第 1 小罒歯が第 2 小曰歯 よりも增大率は大きく，上䪽の場合は 1 根管歯が 2 根管 歯， 2 根茵よりも大であった，近遠心径と煩舌径との間 では大きな差はなく，また䨑根中头部と根尖部において む，それほどの差異はなかった，次に，鼠も增加率の大 きな年齢群は10才代から20・30才代の若年者層であり， この時期のセメント質の増大が大きいことを示してい る。しかし，その後も増大を続けており，乙れは老人ま で行われるものと考えられる.

このセメント質における増粭的な肥厚は，第 2 セメン 卜質の添加が原因であると考えられるが，Zander and Hürzeler (1958 ${ }^{34)}$ は，11才から76才までの上下顎前

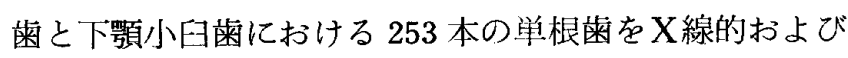
臨床的にしらべて，歯肉䨞の形成や歯槽骨に退縮がない ことを確かめたうえで, 歯根の水平断面標本を作り，各 標本についてセメント質の厚さを測定している．その結 果によると，検索したすべてのセメント質の平均的愿さ は直線的増加を示し，下表のような結果を発表してい る.76才では11才のセメント質の約 3 倍になると述べて

\begin{tabular}{c|c|c|c|c|c}
\hline Age & $20-$ & $30-$ & $40-$ & $50-$ & $60-$ \\
\hline$\overline{\mathrm{X}}$ & 0.095 & 0.125 & 0.155 & 0.185 & 0.215 \\
\hline
\end{tabular}

いる、以上のようなことから, 第 2 セメント質は增鈴に
従い添加を増していくが，年柃による増加は大体一定で あろうと推澌する。

\section{E . 㐘䯋腔}

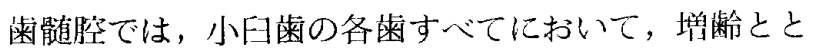
もにその広さを減少していることが絶対值および示数值 の結果より判断される。しかも，その減少傾问は近遠心 径ならびに煩舌径のいずれにおいても同棦に認められ る、歯髄腔の狭窄は単に数值の上で狭くなっているとい うことでなく, 示数值の結果からも判るように, 外径に 対して相対的に狭くなっているといらととである. 更に この減少傾向は年齢的には特に10才代より20・30才代に

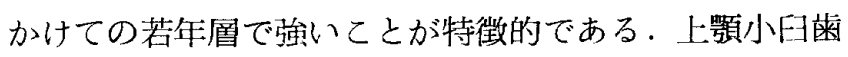
について, 根管数, 歯根数別にみてみると, 単根菌で 1 根管の場合が最も顕著な減少を少していた。

菊池 ${ }^{28)}$ は，上下顎の前䨑および小曰蒾を使用し，煩 側面の最大豊隆部, 煩側蒾頸線の最下点を通る線および 蒾根を 4 等分する部位をそれぞれ横断し, 米冠から根尖 に向い $\mathrm{A} \cdot \mathrm{B} \cdot \mathrm{C} \cdot \mathrm{D} \cdot \mathrm{E}$ 部とした。そして，各部にお いて外形と歯髄腔の近遠心径, 煩舌径を計測し, その髄 院比を（髄腔径：外径×100）で表しているが，著者の 成績とほぼ同様の結果を得ており，やはり20才代と30才 代にかけての若年者間での変化が著明であると述心゙てい る、また，田所 ${ }^{27}$ も上下顎前歯の近遠心径の根管示数 を示しているが，同様に10才代から20才代までの減少に 著しいものがあり，それ以降では大きい変化は存在して いないと報告している。

藤本 $(1958)^{35}$ 'は，X線撮影により歯骵腔形態の堛睮 変化について, A型 (正常型), B 型 (軽度退縮型), C 型 (中度退縮型)， D型 (強度退綰型) の 4 つに分類し ている．その結果，10才代ではA型であるが，20才代で はB型に移り，30才代ではC型が多くなり，40才代では すべての雪がC型となり，50才代になるとD型に変わる と報答している．橋本 $(1977)^{36)}$ は, 藤本 ${ }^{35)}$ と同様の 方法で, 九州人の永久歯粜髄腔の形態を破究している が，10才代から20才代にかけての変化が最も激しく，20 才代から30才代への変化がそれ続き，40才代以降の狄 宱は緩慢になると述べている。

相原 $(1974)^{37}$ は, 解剖学的雬頸部における歯の外径 の煩舌径と同一線上の雪髄腔の煩舌径を計測し，歯髄腔 の比を百分率で表した根管示数を，篠崎 $(1975)^{38)}$ は， 画の煩舌径の歯髄腔面積を外帅面積で徐した割合を表す 面積示数を，また板垣 $(1974)^{39)}$ は，雬の長軸におりる 歯の長さと歯髓腔の長さとの比を, 各々X線撮影により

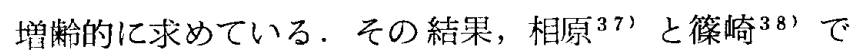


は，30才代沉㧈いて，板畦 ${ }^{91}$ は，20才代で最高值を示 し，以後は漸次減少している。また，この 3 人は最小 自乗法により年齢推定を行い成果を上げている。

Hess $(1921)^{40)}$, Stanley and Ranney $(1962)^{41}$, 北村 $(1927)^{42)}$ ，中川 $(1932)^{43)}$ ，添野 $(1977)^{44)}$ らに

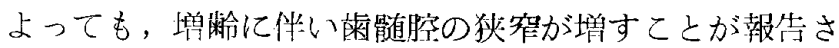
れている．以上の上うな結果を考元合わせると，粜髅腔 は第 2 象牙質の形成などの影響で堌踰的に狭窄在きた し, 特に10才代から $20 \cdot 30$ 才代にかけての若年者曾での 変化が最高であると考えられる。

II . 各部の幅厚示数からみた年齢的変化

\section{A. 外径}

全般的にそれほど大きな増秢的変化はみられないが， 歯冠中央部であるA部では増㱓に伴いわずかに減少がみ られる，すなわち，煩舌径上りも近遠心径の縮小が大き いことを小している。しかし，橉根部においてはD部で わずか罩加傾问を示儿，煩舌径よりも近遠心径がやや 增大していることを示している．以上のことから，菌冠 部では增粉的に近遠心的に圧平を受けていくと考えら れ，エナメル質の堌減と関連していると思われる。蒾根 部では大きな形態変化はみられないが，根尖部付近にお いてセメント質の添加によると思われる変化が，特に烟 舌方向に扔て強く珰められる。

\section{B ．エナメル質部}

七宿においては增齢的に娍少傾向にあり，下顎でも 10 弐代から40才代までの変化は減少をきたしているが，そ れ以降の変化は増加を示した。従ってエナメル質の増齢 的変化すなわち咬耗，磨耗による変化は，上顎と下頡の 40戔代までは，近遠心方向への変化が煩舌方向に打ける のより強いととを示し，下顎の 40 才代以降では，逆に煩 舌方向への変化がやや大きいととを示している.

\section{C. 象牙質部}

象牙質部の增龄に伴う近遠心径と煩舌径との関係は, ほとんど変化がなくわずかに示数值の堌加を示すものが あった程度である、すなわち，菡冠部では増秢に伴い象 牙質は，近遠心方向あるいは煩舌方向への変化には差が なかったというととになる。また，上頡小臼菌の1根管 柬の雨根部ではわずかて煩舌方向への増大が近遠心方沟 のそれよりも大きい傾向があるものと考えられる．同じ く上顎小曰歯の 2 根管㐘では, 近遠心方向, 煩舌方向両 者の閒に增加摔の差は認められなかった。2 根歯におい ても煩側根, 舌側根の近遠心方问, 煩舌方向への増加率 に差異は見出せなかった。

D. セメント質部
セメント質の幅厚示数值の結果から判断すると, 各小 「菌とも增秢的変化は多少誌められたが，全体を通してて はほとんど差はないといえる。すなわち，七メント質の 増加傾向は増秢に伴う近遠心方向と煩舌方向との間で は，ほぼ同様な傾向を示しているものと思われる。

\section{E . 歯髄腔部}

七顎小曰歯においては， 1 根管菌，2根管菊および 2 根菌のいずれについても大きな変化はみられず，歯䯣腔 の堌粭的变化は煩舌方们，近遠心方向ともに汪とんど変 らないものと考えられる。一㖽小四雬では，B部すなわ ち歯頸部では堌秢的に示数値が減少を示し，煩舌方向に 対して近遠心方向への菲䯣腔の維小が強いことがうかが われる、しかしながら，C・D部つまり䨑根中央部およ び根尖部付近では，堌秢とともに示数値の増加傾向が認 められ，㐘髄腔の縮小化は雨頸部とは逆に，近遠心方向 へよりも志しろ煩舌方问へ強いことが想められる。しか も下顎小臼歯のこのような傾向は特に10才代より $20 \cdot 30$ 才代へかけての年魿層において著しく, 菌頸部では近遠 心方向いわ叫る隣接菌牙上りの刺激が強く, 菌根では煩 舌方向からの刺激が強いことがうかがえる。

Gustafson $(1950\rangle^{45}$ は， スエーデン人の霜の研磨標 本について生理的に発睍する 6 個の外形変化要素 咬磨 耗, 雨周症, 第 2 象牙質, セメン卜質添加, 霜根部セx ント質と象牙質の吸収，雪根透明象牙質）が，０度から 3 度までの 4 段階に分けられて, 各個の歯に発現し，そ の総計度数が明らかに年秢と一定の比率でもって増加す ることを兒出している. 本邦でも，北原 $(1968)^{462}$ ，森 口ら $\left.(1975)^{47}\right)$ ，見明 $\left.(1975)^{48}\right)$ によ，ほほ同様の方 法により類似した結果を得ている。

以上述べてきたことから，来は榕合，咀緭，その他の 生理的機能により, 各硬組織および歯髄腔は増路命的に変 化することが㤮められた。すなわち，増秢的にエナメル 質の娍少傾向，象牙質やセメント質の増加傾向とそれに 伴う䨑骮有腔の維小化などが喼められたが，乙れらの現象 は必ずしも…様ではなく年齢群間に差があり，特に若年 者層において最も著明であった．また雪種間あるいは媔 舌方向, 近遠心方向の閒においても差が誋められ，さら

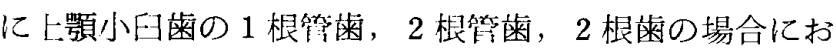
いて，それぞれ珙った状態を示していた。てれらの事実 は歯に加わる生理的刺激，歯周組織との関連などによっ てもたらされるものであるが，歯榷腔の狭窄ということ は，原始的な形態とも何らかのつながりがあるとも考元 られ，いわりる系統発生学的にも検討してみる必要があ ると思われる。 
結

論

ヒトの.上下顎小曰蒾について，曾の各部の横断標本を 作製し，各硬組織ならびに菌髄腔の近遠心径および煩舌 径の計測を行い，それらの増粭的変化の状態を検討し た．特に上類小四来においては 1 根管歯と 2 根管歯，ま た 2 根菌とを区別して調查した。その結果, 各硬組織お よび歯髄腔の増粭的変化，雪の外径に対する各部の相対 的栾化ならびに近遠心方向と煩舌方向との間における年 齢的な差異について，次のごとき結論を得た．

1.エナメル質は近遠心径および頓舌径ともに增柃的 に減少傾向を示し，特に40才代以後の高年龃者層におい

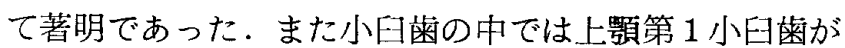
最も著しく，雷の生理的現象がこの歯に強く現われるた めと考える。

2. エナメル貨の増齢的减少傾向が近遠心方向かある いは煩舌方向かとを比べた場合，一般に前者の方が大で あった。しかし下㖽小曰歯では40才代以降においては逆 に煩舌方向への娍少傾向が強かった。

3. 象牙質は増粭とともに増大の傾向を示している。 この傾向は歯冠部を除く他の部位において著明であり， また 1 根管曾が 2 根管霜および 2 根蒾よりも大きかっ た．年粭的には10才代より20・30才代へかけてが著し

く，歯種別では上類第 1 小臼菌が最も顕著であった。
4. 象牙質の増秢的な増加傾向を近遠心および煩舌方 向について比較した場合，ほとんど差異はなかった。

5. セメント質は増齢的に増大傾向を示しているが， 上下頯の第 1 小臼歯が第 2 小曰歯よりも著明であった. 歯根中央部と根尖部とでは大きな差異はなかったが，1 根管曾は 2 根管菌よりも増大率は大きかった，また増大 率の最も著明な年秢風は 10 才代より 20 ・30才代にかけて であった。

6. セメント賈の増柃的な増大傾向を近遠心および煩 舌方向について比較した場合，差は見出せなかった。

7. 㐘髄腔は増粭的に疟くなってくるが, 歯の外径に 対しても相対的にその広さを縮小している．ての傾向は 特に 1 根管歯において著しく，また年龄的には10才代よ り 20 ・30才代へかけての若年者層にて最も顕著であっ た。

8. 蒾髄腔の増秢的な縮小傾向を近遠心方向および煩 舌方向について比較した場合，上額小曰崡では差異はな かったが，下顎小曰雪では粜頸部においては近遠心方向 への縮小化が強く, 柬根中央部と根尖部においては逆に 煩舌方向への縮小傾向が強かった。

稿を終るにあたり，終始御指導と御校閲を賜った山田 博教授に深く感謝の意を表します。また，種々御協力下 さった教室員の方々に唇く御礼申し上げます.

\section{引用 文 献}

1) 山口秀雄：日本人歯牙の生理的咬耗状態に就いて，日本歯科学会雑誌 $22: 251-264,1929$.

2）杤原 博：日本人柬牙の咬耗に関する研究，熊本医会誌 $31: 607-656,1957$.

3) Hojo, M.: On the pattern of the dental abrasion, Okajimas Folia Anat. Jap. 126:11-30, 1954 .

4 ) 中西秀和：現代日本人の咬耗に関する形態学的研究，九州雨会誌 $27: 454-510,1974$.

5) Ireland R. L. : Secondary dentin formation in the deciduous teeth, J. Am. Dent. Assoc. $28: 1626 \sim 1632,1941$.

6) Nalbandian, J., Gonzales, F., et al.: Sclerotic age changes in root dentin of human teeth as observed by optical, electron, and X-ray microscopy, J. Dent. Res. 39:598-607, 1960 .

7) Hopewell-Smith: Some remarks on the human dental pulp, Dental Cosmos 66:489-506, 1924 .

8）浪江幸太郎：第 2 象牙質形成に関する病理組織学的研究, 歯学 $47: 1-41,1959$.

9) 片桐正隆：人の根管壁第 2 象牙質の石灰化像について，雬学 $60: 388-400,1972$.

10) Thomas, B. O. A. : Gerodontology, the study of changes in oral tissues asscociated with aging, J. Am. Dent. Assoc. 33:207-213, 1946. 
11) Soni, N., Huysen, V., et al.: A microradiographic and X-ray densitometric study of cementum, J. Periodontol. 33:372-378, 1962.

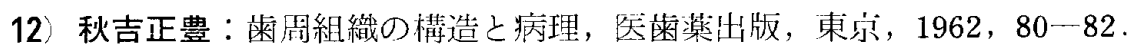

13) Green, D. : Morphology of the pulp cavity of the permanent teeth, Oral Surg. Oral Med. Oral Pathol. $8: 743-759,1955$.

14) Johnson, L. and Bevelander, G.: Histogenesis and histochemistry of pulpal calcification, J. Dent. Res. $35: 714-722,1956$.

15) Rosenstiel, E. : Transparent model teeth, Dental Digest 63:154-157, 1957.

16) Okumura, T. : Anatomy of the root canals, J. Am. Dent. Assoc. 14:632-636, 1927.

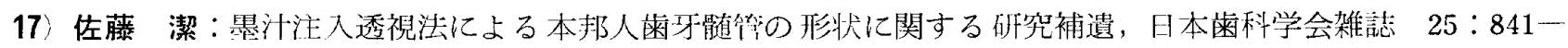
$857,1932$.

18）三沢捨雄：透明標本に上る歯髄腔の形態学的研究，京大口科紀要 $2: 400-424 ， 1960$.

19）殿内純史・高橋和人・他：真空注入法汇上る蒾䯣膑の形態学的研究，菌基礎誌 $13: 403-427,1971$.

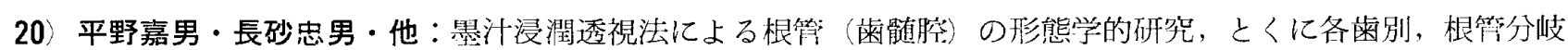
性状の年路的異同について 第 2 編小目菌群, 菌科医学 $22: 1353-1360,1959$.

21）金田義夫：日本人の永久苗に於ける歯根完成時期の研究，歯科月楍 $30 ： 165-172,1951$.

22）山路千秋：本邦人男児雬牙のレントゲン所見に上る年粭推定に関する研究，犯罪誌 $24: 34-70,1958$.

23）人見晃司：歯の成長過程に関する研究一第 1 小目歯一，愛院大㐘誌 $13: 123-147,1975$.

24) 栗岡博良：歯䯣腔 (通称根管) の形態, とくに狭窄化の成因に関する病理組織学的研究, 歯科医学 28 : $498-554,1965$.

25)久家安造：根管形態に関する解剖病理学的研觉，とくに上頻小目雨について, 雬科医学 $32: 256-289$, 1969 .

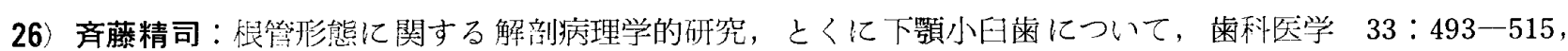
1970 .

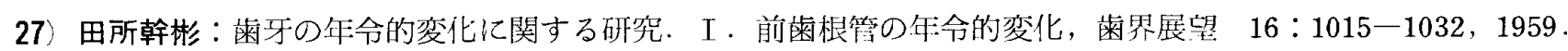

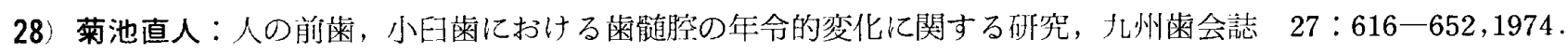

29）藤田恒太郎：㐘の計測規售について，人類誌 $61 ： 27-32,1949$.

30）伊東志朗：菌牙の年令推定に関する研究, 日法医誌 $26: 31-41,1972$.

31）磯川宗七・山田元樹：第 2 象牙質発生に関する実験的研究，解剖誌 $37: 159-169 ， 1962$.

32）加藤 昭：二次象牙質について，医学研究 $33: 119-134,1963$.

33）石川梧郎・秋吉正豊：口腔疗理学 $[I]$, 永末書店, 京都, 1972, 240-258.

34) Zander, H. A. and Hürzeler, B. : Continuous cementum apposition, J. Dent. Res. $37: 1035$ $-1044,1958$.

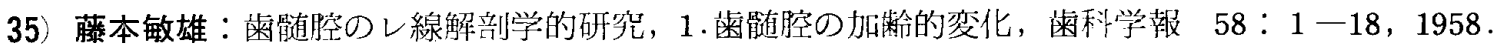

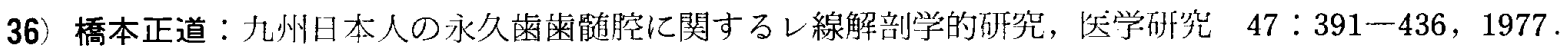

37) 相原俊一：歯随腔の加秢的変化からみた年㱓の推定一根管示数に上る一, 日大歯学 $48: 663$-674, 1974 .

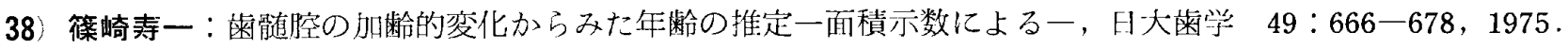

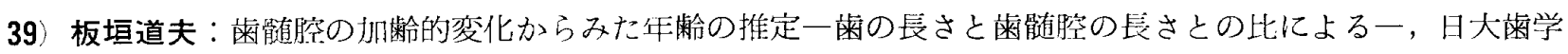
$48: 700-706,1974$.

40) Hess, W. : Formation of root-canals in human teeth, J. Nat. Dent. Assoc. 8:704-734, 1921.

41) Stanley, H. R. and Ranney, R.R.: Age changes in the human dental pulp, Oral Surg. Oral Med. Oral Pathol. 15:1396-1404, 1962. 
42）北村一郎：霜牙のレントゲン写真による年令の鑑定に就いて，口病誌 $1: 143-150,1927$.

43）中川大介：永久雬根管形態の年命による解剖学的変化，歯科学報 $12: 1-19,1932$.

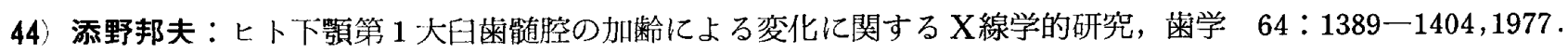

45) Gustafson, G.: Age determinations on teeth, J. Am. Dent. Assoc. 41: 45-54, 1950.

46) 北原祐佐：菌牙硬組織の経年的変化, 日大医誌 $27: 931-946,1968$.

47）森口美津子・上松博子・他：咬耗，歯ぎん䡛および歯根透明象牙質の增齢的変化，歯科学報 $75: 1870 一$ 1879,1975 .

48）見明 清：増龄に伴う歯牙の変化，日雪評論 $387: 73-88,1975$. 